\title{
A NEWLY EXCAVATED PRIVATE HOUSE IN JERASH RECONSIDERING ASPECTS OF CONTINUITY AND CHANGE IN MATERIAL CULTURE FROM LATE ANTIQUITY TO THE EARLY ISLAMIC PERIOD
}

\author{
Achim Lichtenberger, Rubina Raja (first authors) \\ Christoph Eger, Georg Kalaitzoglou, Annette Højen Sørensen (second authors)
}

\author{
La récente fouille d'un habitat privé à Jerash : \\ nouvelles considérations sur les permanences et les changements de la culture matérielle \\ de l'Antiquité tardive au début de la période islamique
}

\begin{abstract}
Depuis 2011, le Projet germano-danois du quartier nord-ouest de Gerasa mène des recherches archéologiques sur la zone la plus élevée de l'ancienne ville enceinte. En 2014, les fouilles ont débuté sur la «terrasse orientale », qui s'étend sur environ $3000 \mathrm{~m}^{2}$ et surplombe l'Artémision d'époque romaine. Cette zone était recouverte par d'importants déblais qui enfermaient les vestiges d'un habitat domestique du début de l'époque islamique, détruit par le tremblement de terre de 749 et jamais réoccupé depuis. Une maison privée a été en partie fouillée (secteur K). Elle ne recouvre aucune phase ni romaine ni byzantine et a été abandonnée à la suite du tremblement de terre avec l'ensemble de son mobilier. L'absence de phases chronologiques antérieures, le mobilier ainsi que la destruction soudaine de cette habitation en font un exemple important qui permet d'entreprendre une étude des permanences et des changements de la culture matérielle de l'Antiquité tardive au début de l'époque islamique. L'habitat et les découvertes de ce secteur sont présentés ici pour la première fois et contextualisés dans l'arc chronologique des VII ${ }^{e}$-VIII siècles. [Trad. de la Rédaction]
\end{abstract}

The ancient city Gerasa, modern day Jerash in northwest Jordan, formed part of the Syrian Decapolis of the Roman period. ${ }^{1}$ The city was an important urban center during the Roman, Byzantine and early Islamic periods among other things with large-scale local pottery production. ${ }^{2}$ The Roman period city of the $2^{\text {nd }}$

1. Kraeling (dir.) 1938; Zayadine (dir.) 1986, Lichtenberger 2003, pp.191-243; Kennedy 2007; Raja 2012, pp.137-189 for earlier research undertaken on the site and further references. Also see Andrade 2013, pp. 160-169 for the most recent substantial summary of the history of the city and further references. See the collection of articles in Syria: Archéologie, Art et Histoire 1989, 66, pp. 1-261, which all also relate to the history and archaeology of Gerasa.

2. Walmsley 2003; 2007, and Simpson 2009 for further literature on Islamic period Jerash. For issues of economy and trade in the region and $3^{\text {rd }}$ centuries CE developed primarily along the northsouth axis of the main colonnaded street (fig. 1), and research has focused on the monuments situated along this street. Remains from the late Hellenistic period have also been found. In this period a small settlement is attested on the Camp Hill in the southern part of the city and across from one of the main sanctuaries, that of Zeus Olympios, which was also founded in the Hellenistic period (fig. 2). ${ }^{3}$ According to legend the settlement was

also see Kennedy 1985; Ward-Perkins 2001; Walmsley 1996; 1997; 2000, as well as Walmsley 2005.

3. Seigne 1989; 1992a; 1992b. For the impact of the positioning of the major sanctuaries on the development of the urban center, see Lichtenberger 2008 and Raja 2009, as well as Raja 2013. 


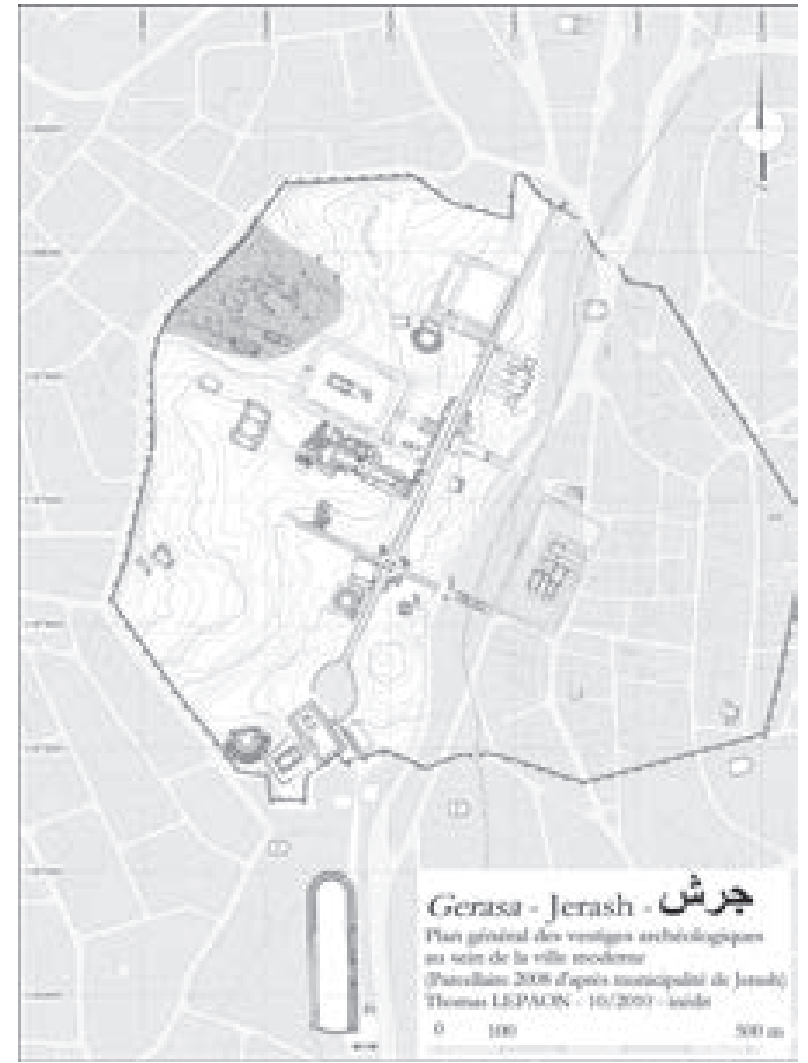

Fig. 1 - City plan of Jerash with the Northwest Quarter marked (after Th. Lepaon 2010, Danish-German Northwest Quarter Project 2014).

established either by Alexander the Great or his general Perdiccas, but it is more likely that it was founded by Antiochus III or Antiochus IV and therefore also named Antiochia at the Chrysorrhoas (the Golden River). ${ }^{4}$ The sanctuary of Zeus was oriented towards the Roman period Oval Piazza, which connected the southern part of the city with the Roman period main street. ${ }^{5}$ Along the main street the typical public monuments of any Roman city in the Greek East are found: a macellum (termed agora in an inscription from the building), shops, public monuments such as the tetrapylon, a monumental nymphaeum, public baths, theaters and the public markets of the city, including a large basilica. ${ }^{6}$ The Artemis sanctuary of the $2^{\text {nd }}$ century CE was the most impressive urban feature

4. See Lichtenberger 2003, 316 for this theory.

5. Raja 2012, pp. 172-175 for the development of this part of the city as well as further literature.

6. Raja 2012, pp. 137-189 for the urban development in Gerasa. The "forum" of the city remains unpublished.

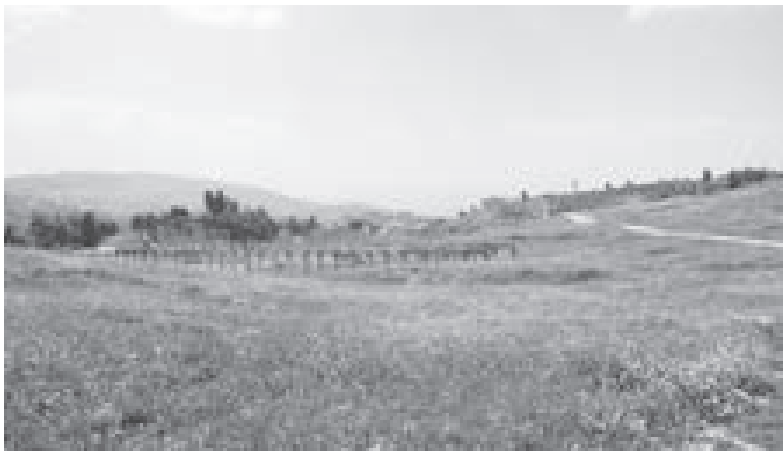

Fig. 2 - The Zeus Olympios sanctuary in Gerasa, view from the Northwest Quarter (phot. Rubina Raja).

Fig. 3 - The Sanctuary of Artemis in Gerasa, view from the Sanctuary of Zeus Olympios (phot. Rubina Raja).

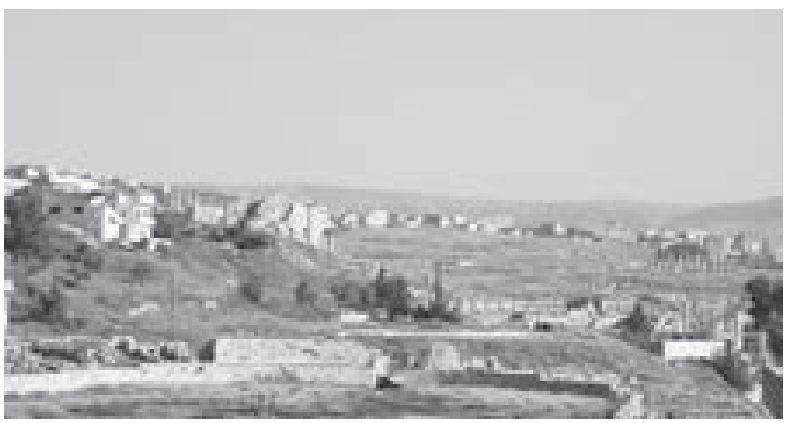

of the central northern part of the city (fig. 3). ${ }^{7}$ The sanctuary was laid out on an east-west axis with extensive propylaea extending across the main street, resulting in an overall size that is rarely matched in the Roman world.

The main north-south street was intersected by two traversing roads, one in the north and one in the south of the city. These linked the city center to the east and the west quarters. The city was laid out on both sides of the river Chrysorrhoas, which dramatically and literally cut the city in two parts. These parts were in antiquity connected by bridges spanning the deep wadi (fig. 4). ${ }^{8}$ The modern town of Jerash covers the eastern part of the ancient city and little archaeological work has been undertaken there. The landscape slopes from the west towards the east to the

7. Fisher 1938b; Parapetti 1989; 2002 for the development of the sanctuary of Artemis as well as Raja 2009.

8. Lichtenberger, Raja 2016a on the water supply of Gerasa and the impact of the river on the city's topography and urban image and ideology. 


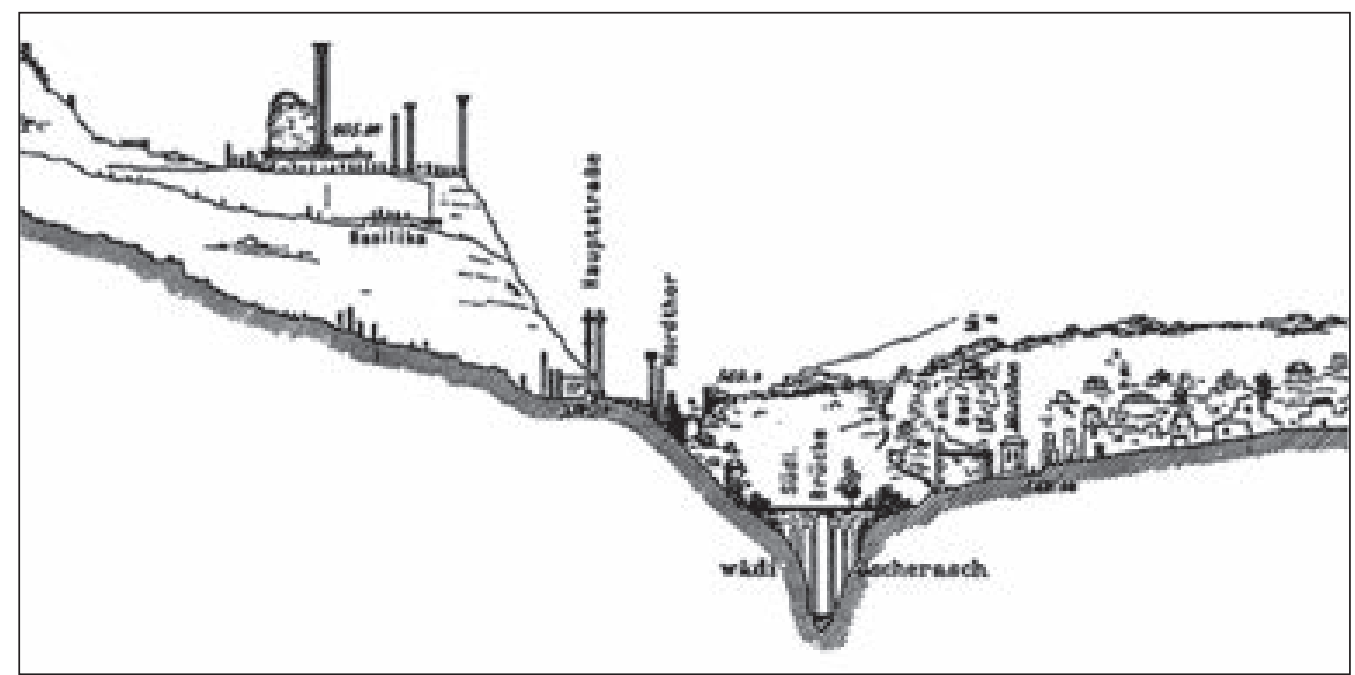

Fig. 4 - Profile drawing of Gerasa, from Schumacher 1902 (ZDPV 1902).

deep wadi and from the eastern side of the city towards the west also towards the steep wadi. Schumachers plan from 1902 showing a profile of the site, which although exaggerated, gives a good impression of the dramatic topography of the site. This extreme topographic location of the city has been ignored until now.

The city was enclosed by more than 4 kilometers of city walls with towers, bastions and gates punctuating the walls at various points. Various dates for the city walls have been proposed by scholars, with suggestions ranging from the Hellenistic period to Late Antiquity with no consensus yet reached. ${ }^{9}$ The city prospered during the

9. Detweiler 1938a; 1938b for the North and South gates. Fisher 1938a, pp. 12-14 for a description of the visible fortifications. Kraeling 1938 , p. 41 was the first to advocate a first century CE date for the city wall based on epigraphic evidence supposedly belonging to the Northwest Gate. This date has been questioned by Seigne on the basis of his excavations by the South Gate. Seigne argues for the erection of the city walls in this area in the late $3^{\text {rd }}$ or early $4^{\text {th }}$ century CE (Seigne et al. 1986, pp. 55-59; Seigne 1992a, p. 331). This date is disputed by Kehrberg and Manley 2001, who argue for an earlier date in the first quarter of the $2^{\text {nd }}$ century CE for the western parts of the city wall (followed by Lichtenberger 2003, p. 193; Raja 2012, pp. 142-144). The Jarash City Walls Project headed by Kehrberg, Manley, and Kennedy excavated strategically located trenches relating to the city walls and supplied data for an early $2^{\text {nd }}$ century CE dating, but without publishing all the related finds (Kehrberg and Manley 2001; 2002; 2003). In many places it is obvious that spolia were built into the city wall, which is a clear indication that at least some parts of the walls were heavily renovated or rebuilt at later points in time. All necropoleis of the second and third centuries CE are located outside the course of the city walls, indicating that the limits of the city were located here (walled or unwalled). For the necropoleis see Seigne 1992a, pp. 340-341, ills. 7-9. On city walls in general in the Decapolis region see also the summary survey by Smith 2011, 501-502 on Gerasa. late Roman, Byzantine, and early Islamic periods as well as in the early Mamluk period. ${ }^{10}$ Many churches and two mosques attest to the flourishing religious life of the city and to the continuation of private sponsorship in public space.

Since the beginning of major excavations in the 1920s, research has focused on the major public monuments along the main streets. Not much is known about the development of the city outside these central areas; in addition excavations of domestic architecture are sparse. ${ }^{11}$ Despite the important work done by Walmsley and his teams over the years, much remains to be said about early Islamic period Jerash and in particular little is known about private domestic contexts..$^{12}$ In this contribution we present results stemming from an excavation of parts of a private house dating to the early Islamic period excavated in 2014 in the Northwest Quarter of the ancient city.

10. For literature and further references see for the late antiqueByzantine period, see Crowfoot 1938; Wharton 1995, pp.64-104; March 2009; Raja 2015. For the transition between late antique and Byzantine Palestine see in general Avni 2014. For early Islamic Jerash, see Blanke et al. 2007; Walmsley and Damgaard 2005. For the post-Umayyad periods see Pierobon 1983; 1984; Tholbecq 1997-1998; Lichtenberger, Raja, 2016b.

11. Most excavations of recent years have also encountered some domestic architecture. However, a comprehensive study of this architecture currently remains a desideratum. See Fisher 1938c, and in particular pp. 283-294 for domestic housing dating to the Byzantine period. Furthermore see Gawlikowski 1986, pp. 107-136 for an Umayyad domestic complex situated on the south decumanus. 12. See note 2 for further references as well as Blanke et al. 2007. 


\section{The Danish-German Northwest Quarter Project: the 2011-2014 campaigns}

A new archaeological project, which was begun in 2010, has aimed at examining the settlement history of the so-called Northwest Quarter of Jerash in all periods. ${ }^{13}$ The Northwest Quarter is the area to the west of the Artemision, stretching from the sanctuary to the city walls (fig. 1 with the Northwest Quarter marked). It is the highest area within the walled city of Gerasa. Apart from the so-called Synagogue Church, which was excavated in two weeks and published in the comprehensive publication from 1938 edited by Kraeling, this area has been left largely unexplored..$^{14}$ In 1983, two trenches within the area of the Northwest Quarter were excavated by V.A. Clarke andJ. Bowsher. Both were presented in a short report. One of the trenches (trench NWG) was located app. $60 \mathrm{~m}$ south of the supposed Northwest Gate and, according to the excavators, revealed two walls, as well as material finds that dated to the $3^{\text {rd }}$ century $\mathrm{CE}^{15} \mathrm{The}$ second trench further to the northeast (called trench $\mathrm{E}$ by the excavators) was excavated in order to clarify the possible continuation of the North Decumanus, but did not yield any conclusive results. ${ }^{16}$ The main reasons for exploring the Northwest Quarter within the framework of a longer-term archaeological project are first and foremost the prominent topographical location, its vicinity to the Artemision, its relation to the city walls, and its location in relation to the supposed east-west main streets on the north and south sides of the hill.

The Northwest Quarter covers app. 4 ha and is characterized by a hill dominated by a flat plateau. The soft white limestone bedrock, which is dominating for the region, is close to-and even visible on-the surface in several places across the hill. Furthermore, collapsed structures made of the local soft whitish limestone are also visible on the surface. The hill slopes to the north and south as well as towards the east, where the Sanctuary of Artemis is situated. The Northwest Quarter was used

13. For the new excavations in the Northwest Quarter of Jerash see: Lichtenberger and Raja 2012; Kalaitzoglou et al. 2012; forthc.(a); forthc. (b); forthc.(c); Lichtenberger et al. forthc.(a); forthc.(b); forthc.(c); Lichtenberger, Raja 2016c.

14. On the Synagogue Church: Crowfoot and Hamilton 1929; Crowfoot 1995, pp. 234-239; Dvorjetski 2005. Some remains in this area were already described by Schumacher 1902, in particular p. 121, pl. 6 for the remains. See Lepaon 2011 for an updated plan of Jerash which includes some features in the Northwest quarter. Some unpublished plans from the Yale Expedition remain in the archives at the Yale University Art Gallery. Thanks to Lisa Brody, Megan Doyle and Susan Matheson, we were able to consult these in 2012 and 2015 and verify that they include a sketch of the large rectangular structure to the East of the building as well as several wall structures to the West.

15. Clark and Bowsher 1986, in particular p. 345 for the sounding relating to the possible decumanus.

16. Clark and Bowsher 1986, pp. 344-345. for farming after the Circassian resettlement of the area in the $19^{\text {th }}$ century. An air photo from 1917/1918 shows the area with dense vegetation which attests to farming or grazing (fig. 5).

In 2011 a surface and architectural survey was undertaken during a two-week long campaign alongside an extensive geophysical examination. These examinations resulted in a detailed plan of the surface structures as well as a plan of the area's geophysical morphology. ${ }^{17}$ The architectural survey plan gives a clear impression of how the structures were constructed in alignment with a terrace system that extended across the hill, following the sloping topography and facilitating extensive construction (fig. 6). The results of the geomagnetic examinations supported the initial impression gained from the survey, namely that a dense settlement pattern was to be found on the hill (fig. 7). Georadar examinations were also conducted, but the results were unclear, due to the similarity between the limestone of the natural bedrock and the limestone used in the architecture. Prominent features that are visible on the surface and survey plan include a large cistern, the largest installation for water in Gerasa (fig. 8), as well as the remains of a monumental complex built partly of spolia, situated on the very top of the hill. ${ }^{18}$ These features were the main focus of the project in the campaigns that followed, which centered on understanding the development of this area.

During the campaigns of 2012, 2013 and 2014 a total of 12 trenches were excavated in different areas of the Northwest Quarter (see fig. 6 for trench locations). Most trenches were excavated either to bedrock or virgin soil except where it was deemed necessary to preserve younger in-situ installations, such as the find of a byzantine kitchen installation (trench D) (fig. 9). ${ }^{19}$ The excavations have yielded material dating as early as the Neolithic period (trench A), but which came from upper fill layers of mixed material. ${ }^{20}$ This soil may have been brought from elsewhere in a later period in order to prepare the hill for agricultural use. Only one fragment of Early Bronze Age material (trench D) has been documented and no Iron Age material has been recognized. ${ }^{21}$ There are some Hellenistic black glazed pottery sherds (fig. 10) (trenches $\mathrm{C}$ and $\mathrm{H}$ ) and Hellenistic glass (fig. 11) (trenches $\mathrm{E}$ and $\mathrm{H}$ ) but these fragments do not come from undisturbed contexts. ${ }^{22}$ Early Roman

\footnotetext{
17. Kalaitzoglou et al. 2012.

18. Schumacher 1902, p. 121; Lichtenberger, Raja 2012; 2016b and c; Kalaitzoglou et al. forthc.(a) and (b).

19. Kalaitzoglou et al. forthc.(a).

20. Kalaitzoglou et al. forthc.(a) and Lichtenberger et al. forthc.(a).

21. Lichtenberger et al. forthc.(b), cat. no. 180 for the EBA sherd found in a non-stratified context.

22. Lichtenberger et al. forthc.(a), cat. no. 1; Lichtenberger et al. forthc.(b), cat. nos. 153 and 154 .
} 


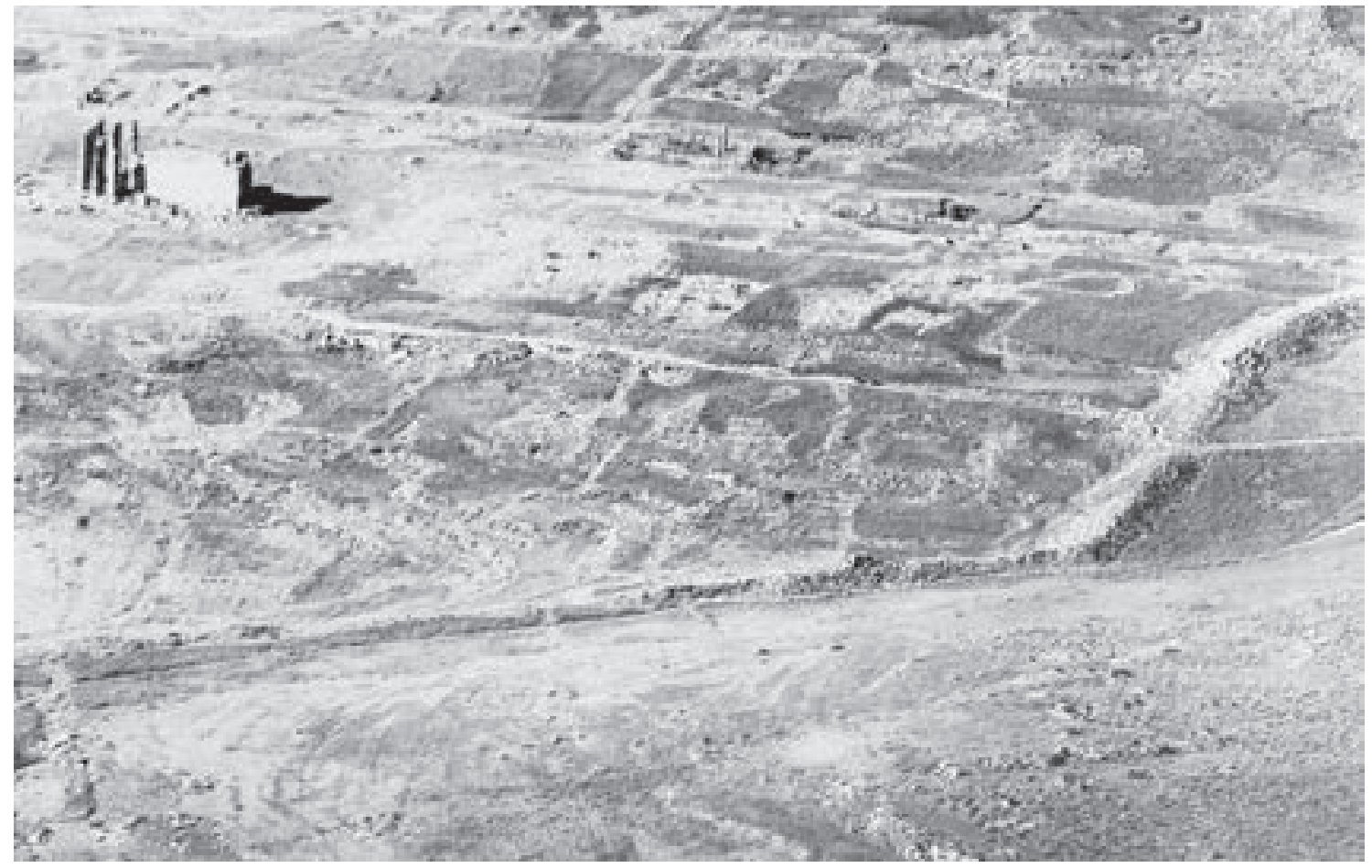

Fig. 5 - The Northwest Quarter with dense vegetation, detail of an air photo 1917/1918 (Bayerisches Hauptstaatsarchiv BS-Palästina 1127a).

Fig. 6 - Map of the Northwest Quarter with trenches of the years 2012-2014 and the south slope survey area of 2014 (Danish-German Northwest Quarter Project 2015)

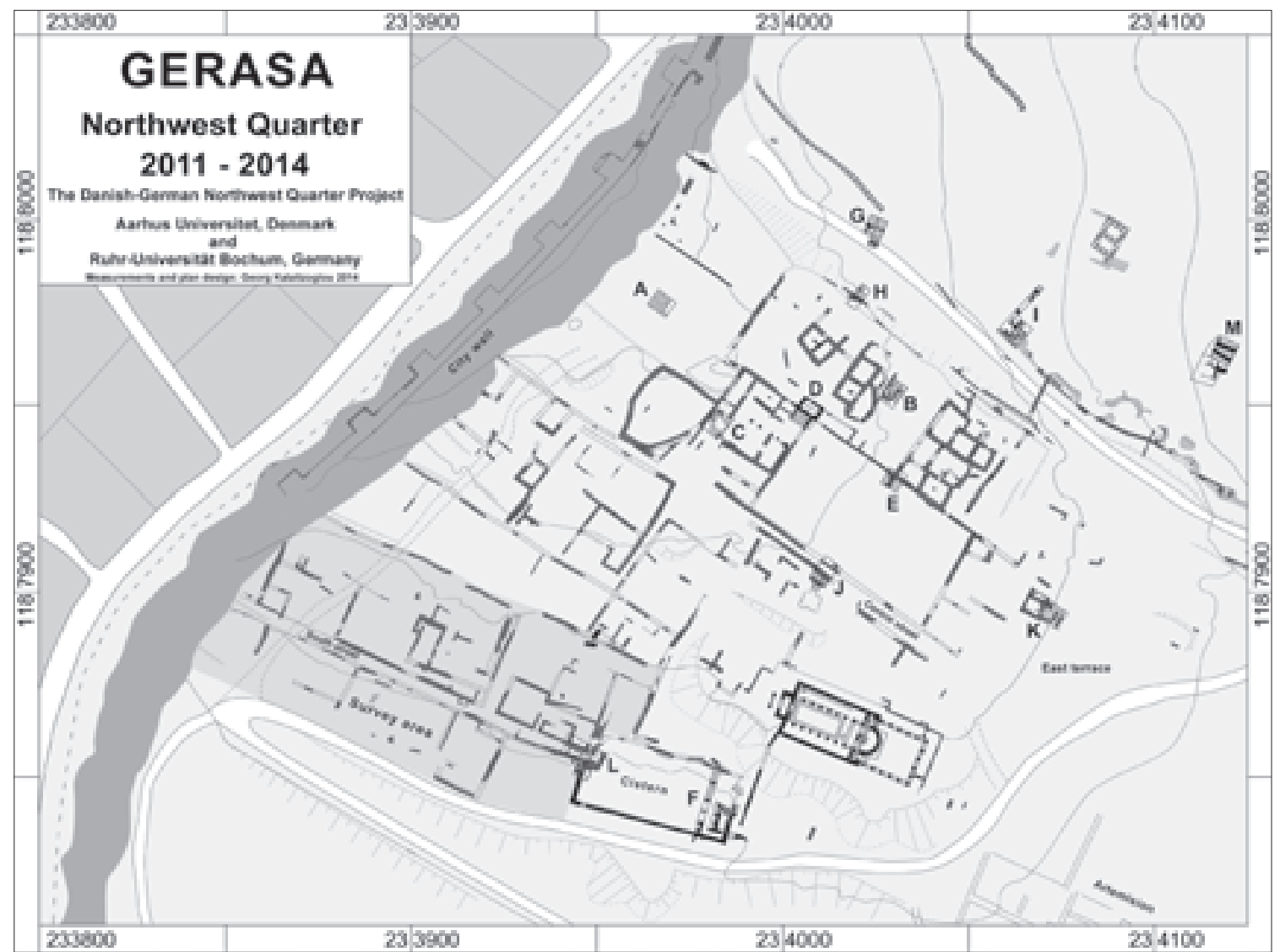




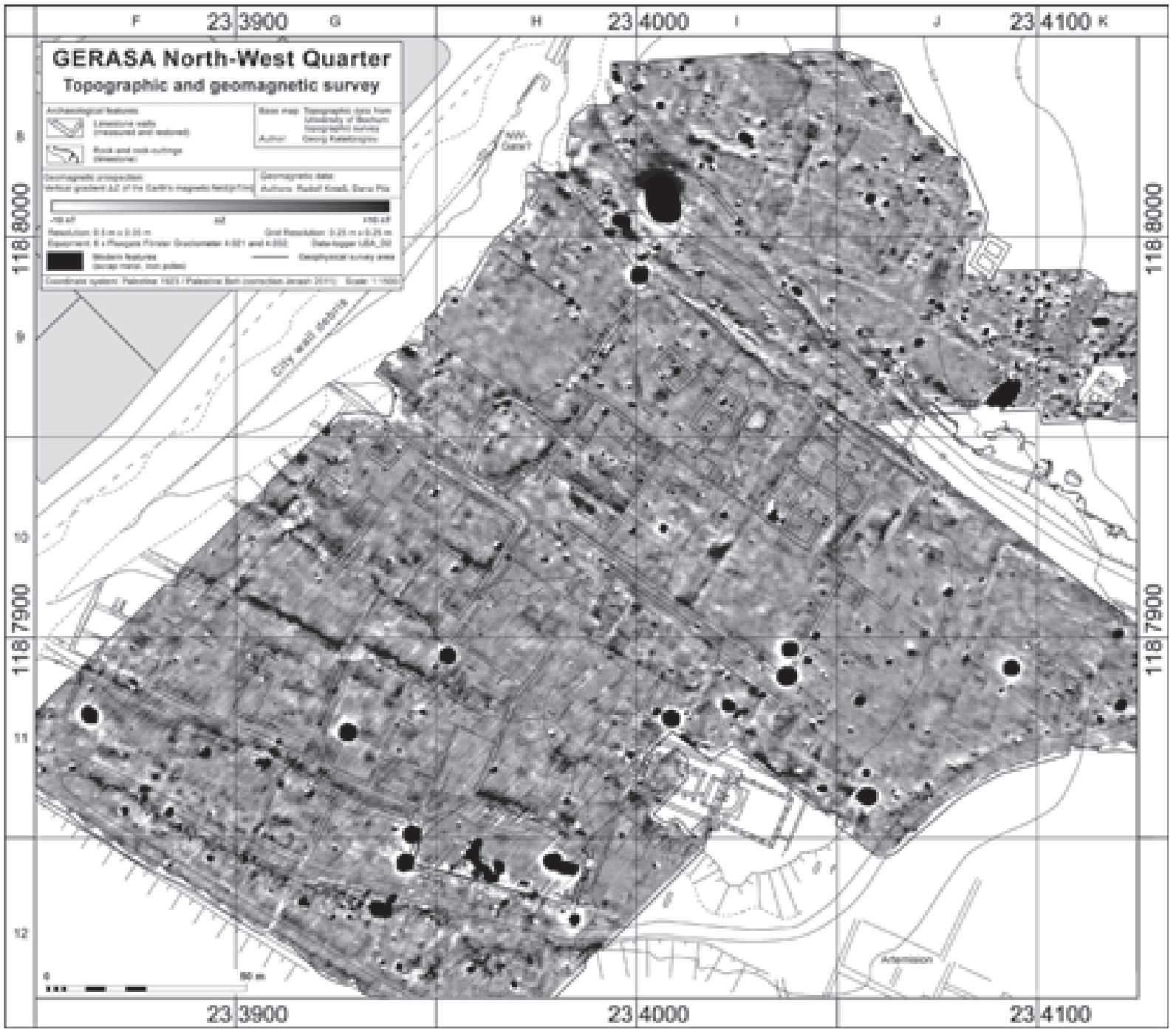

Fig. 7 - Plan of the geophysical (geomagnetic) survey in the Northwest Quarter (DanishGerman Northwest Quarter Project 2014).

Fig. 8 - Plan of the large cistern on the south slope (DanishGerman Northwest Quarter Project 2013).

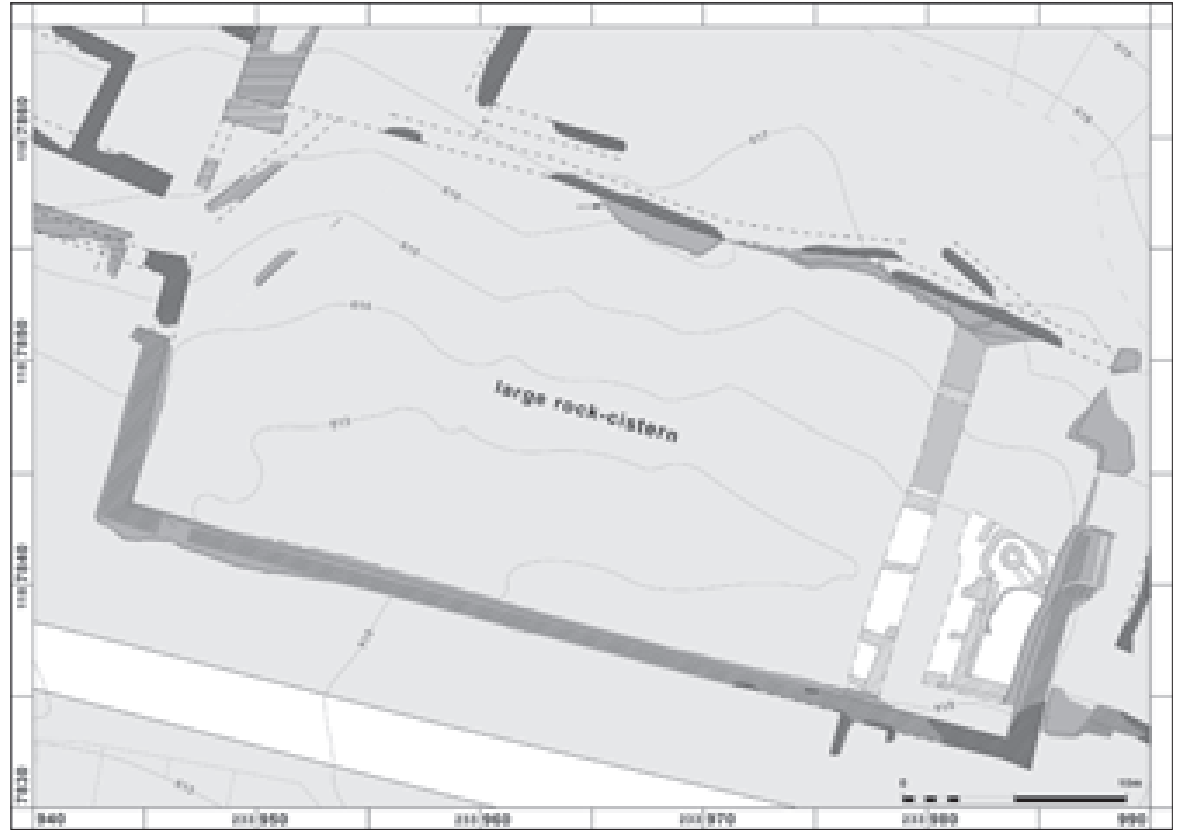




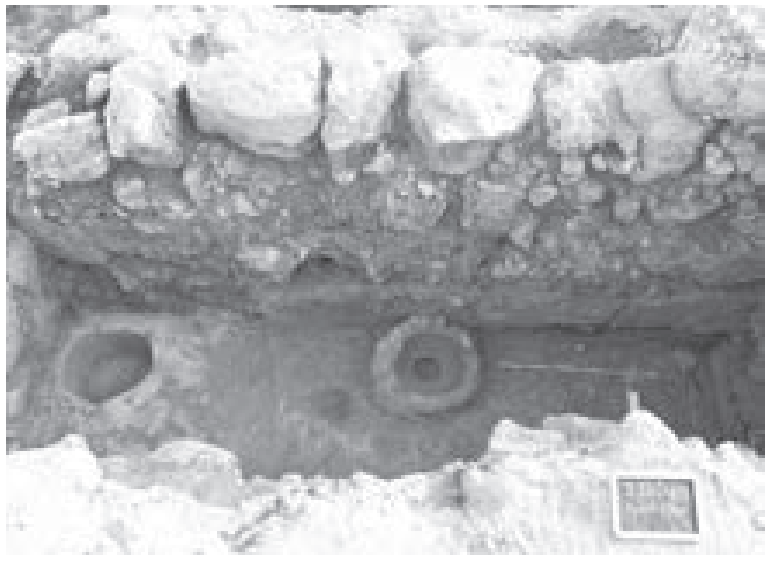

Fig. 9 - Photo of the Early Islamic period kitchen in trench D, view from north (Danish-German Northwest Quarter Project 2013).

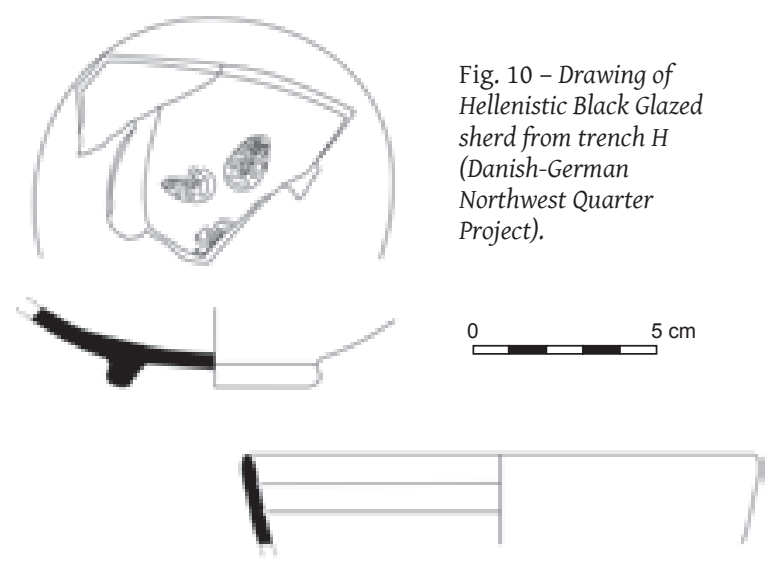

Fig. 11 -Drawing of a Hellenistic glass sherd from trench $E$ (Danish-German Northwest Quarter Project). material was also found, but only in sparse amounts and not in direct association with built structures (trenches A, $\mathrm{F}, \mathrm{G}$ and $\mathrm{H}){ }^{23}$ Evidence for extensive building activity, covering more or less the whole hill, is only attested from the later Roman period ( $3^{\text {rd }}$ century CE) onwards. ${ }^{24}$ The most prominent feature is the famous Synagogue Church, built as a synagogue in the $4^{\text {th }}$ or $5^{\text {th }}$ century CE and turned into a church in the $6^{\text {th }}$ century $\mathrm{CE}^{25}$ Although synagogues in the diaspora were sometimes located outside cities, this does not seem to have been a general rule. ${ }^{26}$ The location therefore provides no information about the urban context of this monument other than confirming the preference for positioning synagogues at the highest point within ancient settlements. ${ }^{27}$ No archaeological evidence for the presence of necropoleis, either on the hill or on the slopes of the hill within the walled city, has been detected in the extensive survey or in the following excavation campaigns in the Northwest Quarter. ${ }^{28} \mathrm{~A}$

23. Lichtenberger et al. forthc.(a), cat. nos. 2 and 165; Lichtenberger et al. forthc.(b), cat. nos. 4, 5, 7, 8, 15, 50, 97 and 137.

24. Lichtenberger, Raja, 2015a on termination deposits of the $3^{\text {rd }}$ century CE in trench A on the top of the hill inside a building, which speaks for earlier activity.

25. Crowfoot, Hamilton 1929 for the first publication of the synagogue in Gerasa.

26. For pre-70 CE diaspora synagogues situated in remote areas in cities see Levine 2000 , p. 120. See, however, the many examples of later diaspora synagogues within the central areas of cities: Levine 2000, pp. 232-287.

27. Tosefta, Megilla 3,22; MidrTan 3; Dvorjetski 2005, p. 141.

28. Seigne 1992a, 335-337 traces a pre-Hadrianic necropolis, qualified, however, with a question mark, on the northern slope of the Northwest quarter. So far, no tombs have been identified by the Danish-German team, neither during the extensive survey nor during the excavation campaigns. No human bones have been identified either. preliminary study of the bone material from the excavations has not yielded a single human bone. ${ }^{29}$ This evidence calls into question whether extensive necropoleis existed in this area at all in the Hellenistic and Roman periods, since it is to be expected that some human bone material would have been found if this had been the case.

The Byzantine and Umayyad periods, which are often difficult to distinguish through their material culture since the transition from one to another is not distinctly visible, are clearly the most prosperous phases of the Northwest Quarter of Gerasa. ${ }^{30}$ During this time the hill was densely covered with domestic and industrial installations. ${ }^{31}$ A complete oil press, excavated in the 2012 campaign east of the highest area of the quarter, attests to such industrial activities (fig. 12). ${ }^{32}$ Furthermore, pressure water pipes excavated on the plateau as well as on the north ridge of the Northwest Quarter during the 2013 campaign attest to the fact that this part of the city was well integrated into the water supply system of the city from the Roman period onwards (fig. 13, trench $\mathrm{E}$ as well as fig. 14, trench $\mathrm{H}){ }^{33} 14 \mathrm{C}$ AMS-analysis, which was undertaken on the mortar fitting the pipes together,

29. Lichtenberger et al. forthc.(c) includes a section by Pernille Bangsgaard on the bone material.

30. Avni 2014 for the transition from the Byzantine to Early Islamic period in this region.

31. See above note 14 for publications relating to the work in the Northwest Quarter by the Danish-German team.

32. See Kalaitzoglou et al. forthc.(a) and Lichtenberger et al. forthc.(a) for relevant material relating to these trenches.

33. For results relating to the work done during the 2013 campaign see Kalaitzoglou et al. forthc.(b) and Lichtenberger et al. forthc.(b). 

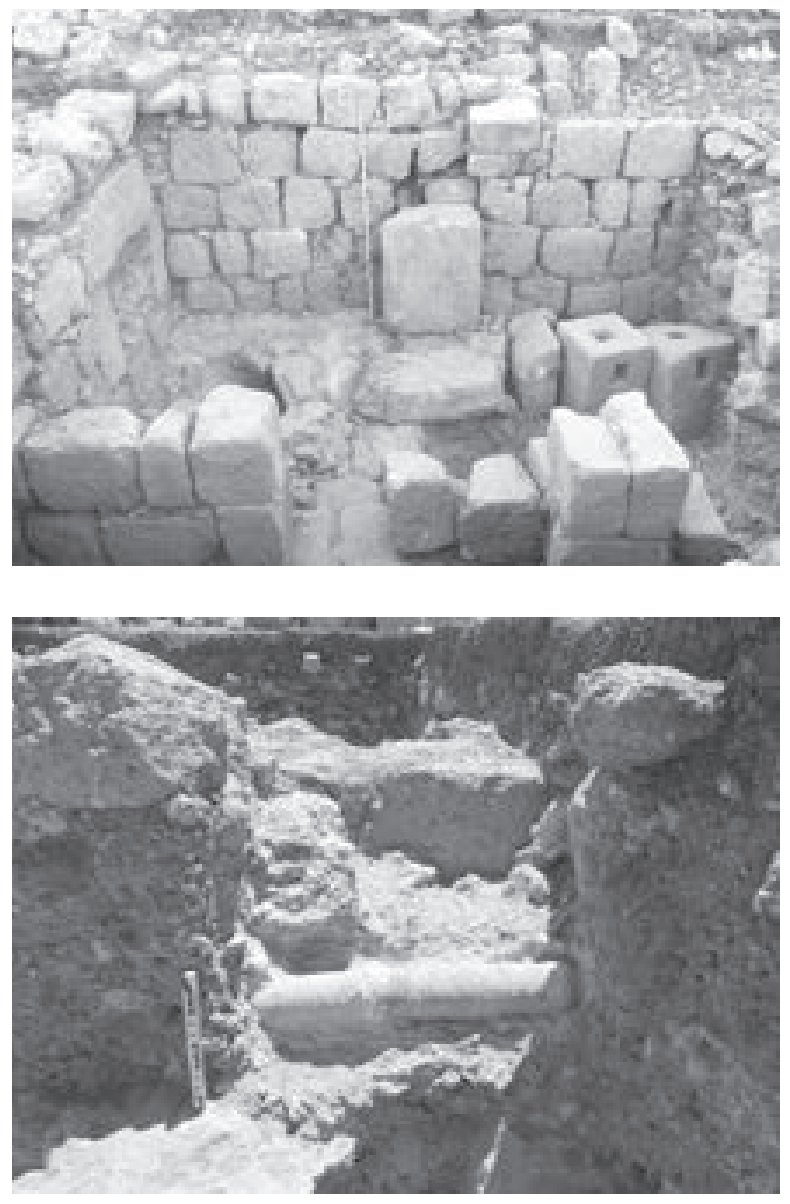

suggests a construction date in the $3^{\text {rd }}-4^{\text {th }}$ century $\mathrm{CE}^{34}$ Several earthquakes occurred in the Byzantine and Early Islamic periods, and the massive earthquake of 749 CE seems to have brought an end to a large-scale settlement at Jerash. ${ }^{35}$ This was followed by a gap in, or at least a massive reduction of, settlement between the Abbasid (at the latest) and Ayyubid periods. However, the Northwest Quarter shows considerable evidence for settlement from the Ayyubid period onwards and well into the Mamluk period. ${ }^{36}$

34. Lichtenberger et al. 2015. This date provides a good fit with the water pressure pipes that were excavated south of the Northwest Quarter running along the city wall. They were dated to the $2^{\mathrm{d}}$ century CE by the excavator, but it remains unclear whether these were fed by water installations in the Northwest Quarter (Kehrberg and Manley 2003, pp. 84-86).

35. On the earthquake of $749 \mathrm{CE}$ cf. Tsafrir and Foerster 1992. The last seasons of archaeological work in Jerash have shown that settlement continued on a smaller scale after the earthquake, reaching well into the Abbasid period (see e.g. Blanke et al. 2010).

36. Lichtenberger, Raja 2016b.
Fig. 12 - Photo of the late antique oil press in trench B, view from east (DanishGerman Northwest Quarter Project 2012).

Fig. 13 - Clay water pressure pipe in trench E, view from west (Danish-German Northwest Quarter Project 2013).

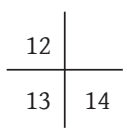

Fig. 14 - Clay water pressure pipe in trench $H$, view from east (Georg).

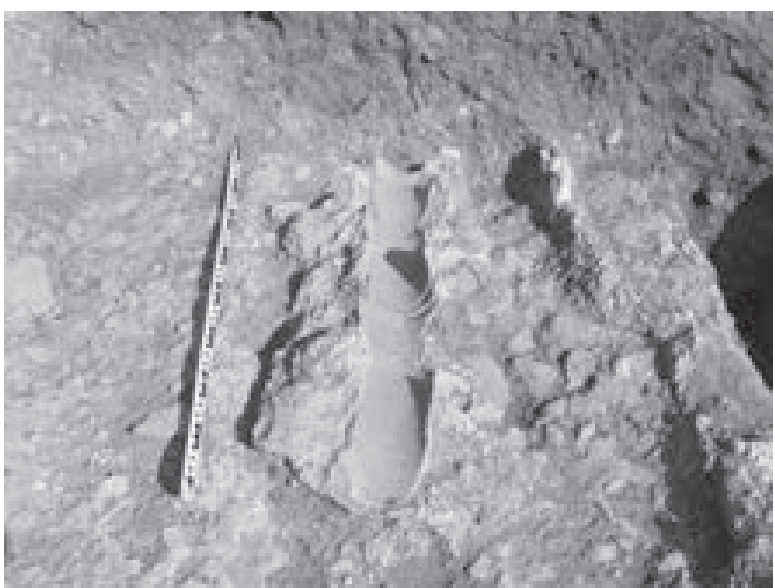

Important results were gained concerning the urban organization, street layout and infrastructure of the Northwest Quarter in the campaign of $2014 .^{37}$ It was clarified that the Roman North Decumanus running from the Tetrapylon on the main street towards the west did not extend further to the west than where the last stretch of it had been excavated close to the North Theatre (trenches I and M) (fig. 15). ${ }^{38}$ Further investigation of the South Street on the other side of the hill suggests that it had been planned and implemented most likely as late as the Byzantine period (see fig. 6 for location of trench L). This fits the pattern of a newly excavated street in trench J located centrally on the very top of the hill, the layout of which dates in its first phase

37. On the urban plan and layout of Gerasa/Jerash in general see e.g. Kraeling (dir.) 1938; Zayadine (dir.) 1986; Seigne 1992a; Kennedy 2007; Kehrberg 2011, p. 18; Raja 2012, pp. 137-189.

38. Clark et al. 1986, in particular pp. 206-207; Lepaon 2011 for the otherwise most up-to-date city plan of Jerash. 


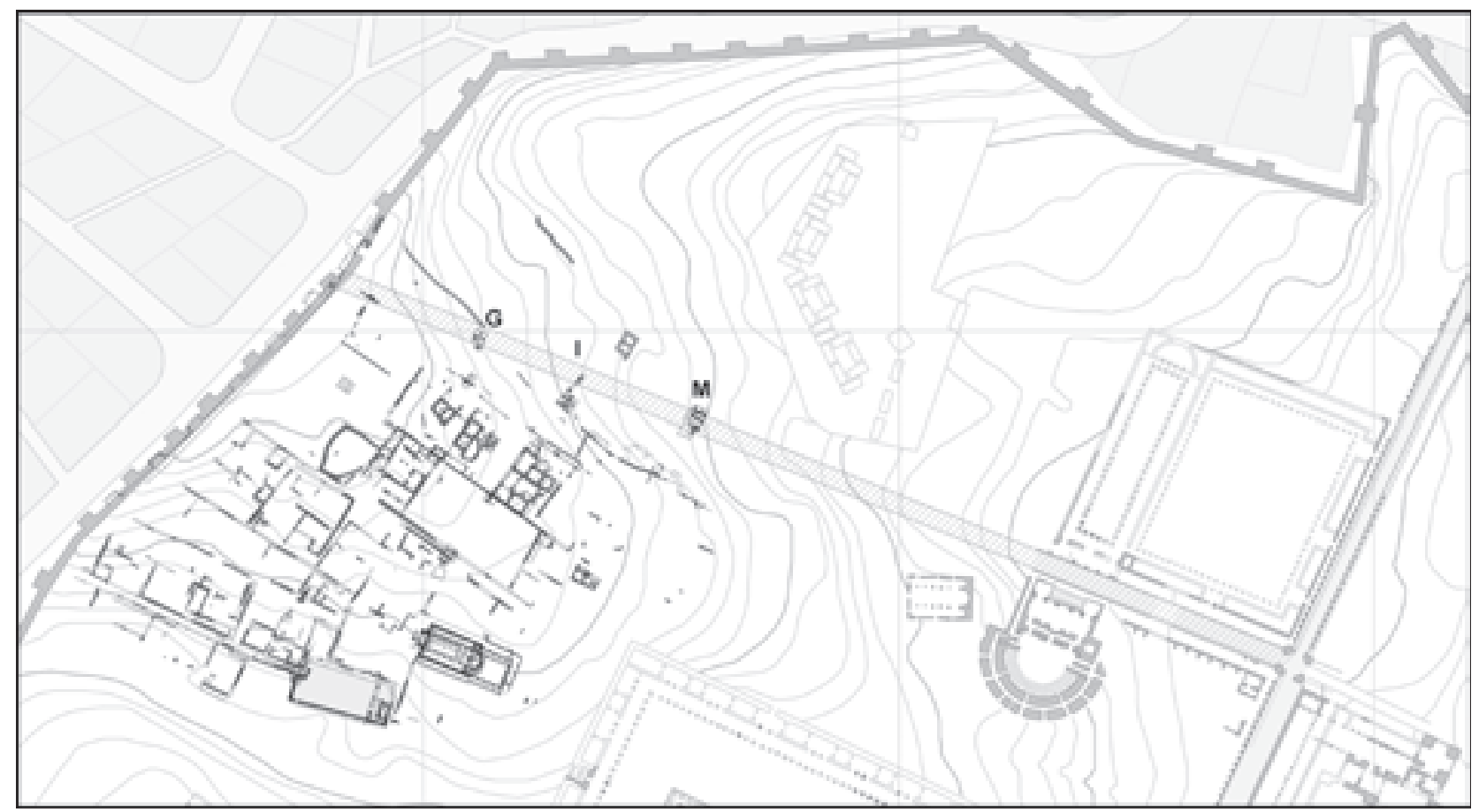

Fig. 15 - Plan of the Northwest Quarter with projection of the presumed North Decumanus (Danish-German Northwest Quarter Project 2015 after Th. Lepaon 2010).

to either the late Roman period or the Byzantine/ Umayyad periods. This street, the so-called "Central Street", runs from east to west and followed the natural terrain like the south street did. Its course was already visible in the magnetogramme of the geophysical survey undertaken in 2011 (see fig. 7). Extensive organization of this area seems to have taken place from the late Roman period onwards.

A considerable amount of finds from the 2014 campaign, however, can be related to earlier periods (Hellenistic and Roman). Especially a cave complex excavated in trench $\mathrm{J}$ and parts of its deliberate massive fill layers, consisting in large parts of broken ceramics which were not very worn, attest to considerable building activity in Roman to Late Roman times on the hill (figs. 16-18). The major part of the finds, however, point to a Byzantine to Early Islamic date for constructions. On the so-called East Terrace an undisturbed destruction layer from the end of the Umayyad period in trench $\mathrm{K}$ turned out to be of great importance and will be the focus of this article (fig. 19). Only few finds of Ayyubid-Mamluk date were discovered and these periods were almost absent on the southern hill slope where a ceramic survey was undertaken in 2014.

\section{South slope survey}

A surface survey of an area on the south slope was undertaken in 2014. This area of about $5436 \mathrm{~m}^{2}$ between trench $\mathrm{L}$ and the debris of the city walls is densely dotted with structures visible on the surface (figs. 7 and 21). This area was divided into three parallel strips with in total 42 constructed units for the purpose of the survey. Within these units a representative amount of surface finds was collected. Although the find analysis is still in progress two preliminary results are worth mentioning: 1 / finds of the Middle Islamic periods are rare. This confirms the assumption that the Ayyubid-Mamluk settlement and activities were limited to the vicinity of the Mamluk hamlet on top of the Northwest Quarter. ${ }^{39}$ 2/ An increasing amount of Roman pottery was found the closer we got to the city walls. Although this concentration of Roman surface finds most likely results from a bulldozer lane leading up the hill, it is obvious that the original backfill of the demolished retaining walls of the terraces must have

\footnotetext{
39. Lichtenberger, Raja 2016b top of the hill in the Northwest Quarter. Furthermore see Kalaitzoglou et al. forthc.(a) as well as Kalaitzoglou et al. forthc.(b).
} 

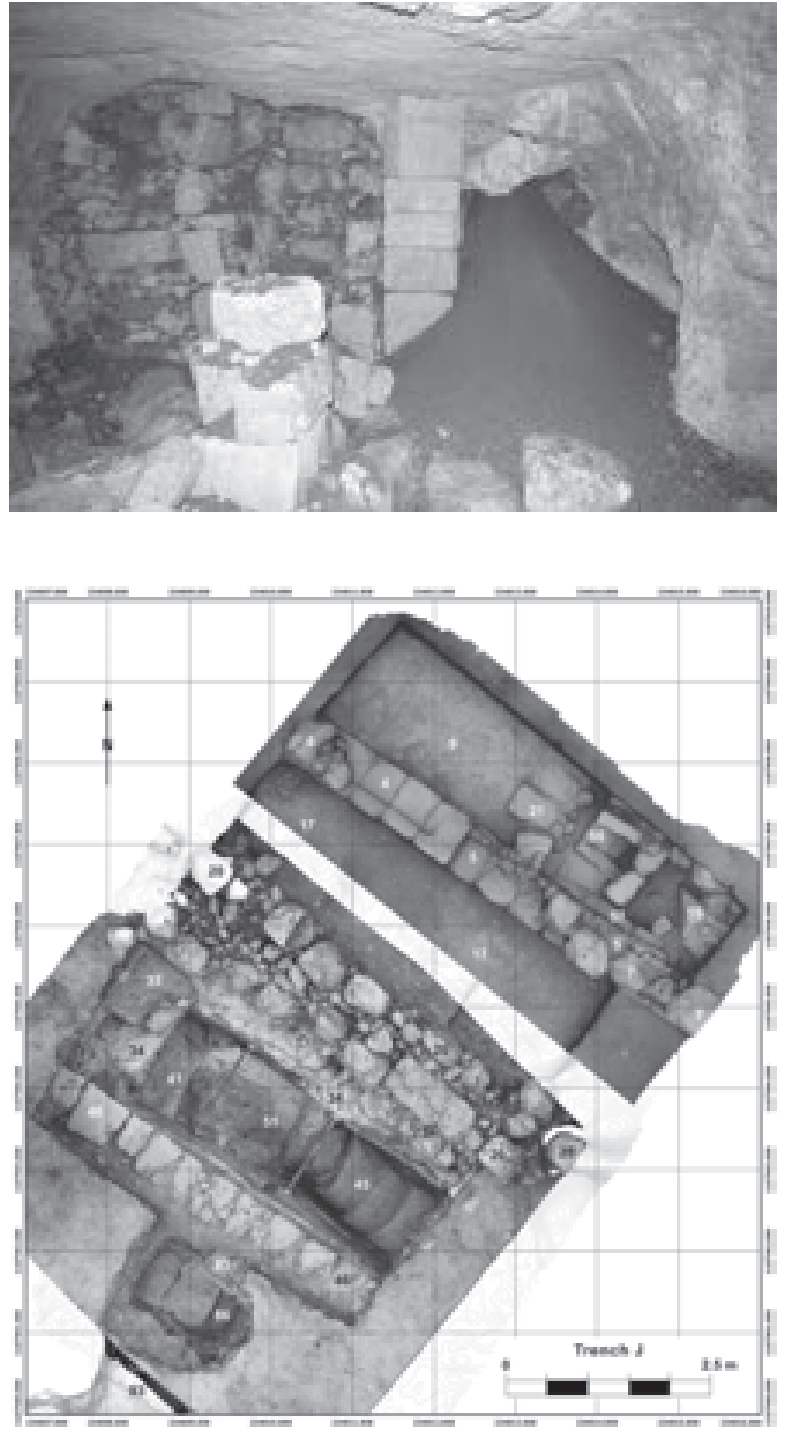
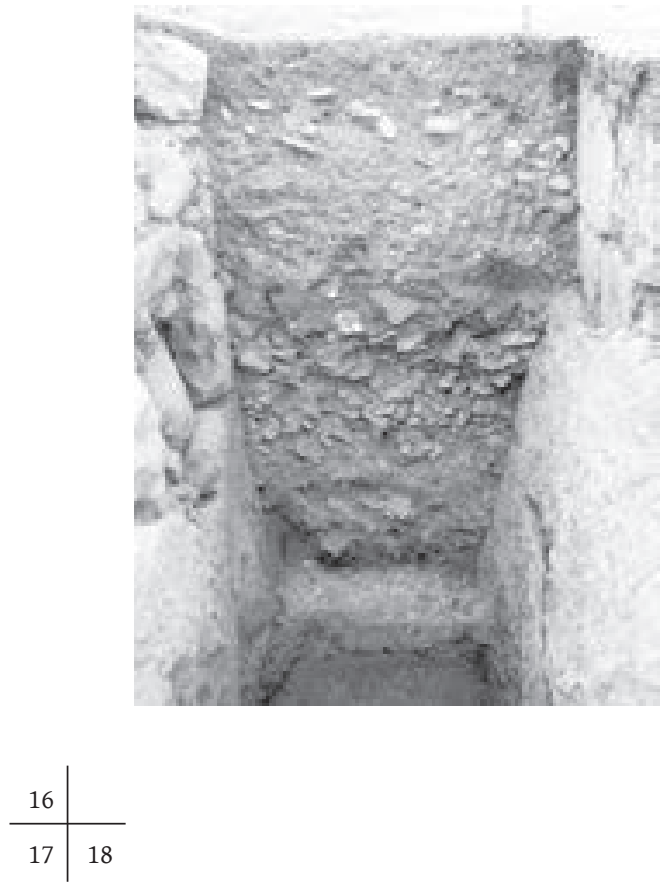

Fig. 16 - Trench J, view from north into the cave (Danish-German Northwest Quarter Project 2014).

Fig. 17 - Plan (photogrammetric) of trench J with staircase leading down (Danish-German Northwest Quarter Project 2015).

Fig. 18 - Trench J, east profile with pottery fill above the staircase, view from west (Danish-German Northwest Quarter Project 2014).
Fig. 19 - Trench K, situation before the excavation, view from west (DanishGerman Northwest Quarter Project 2014).

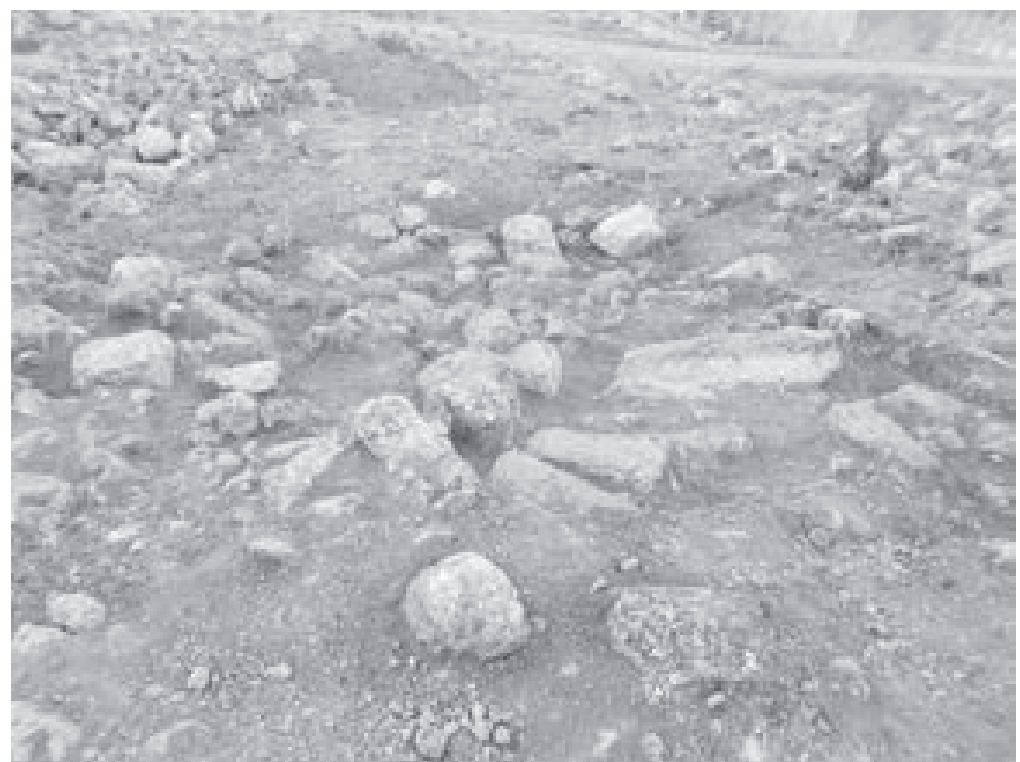


Fig. 20 - Overview of the pottery survey area on the South Slope, view from west (Danish-German Northwest Quarter Project 2014).

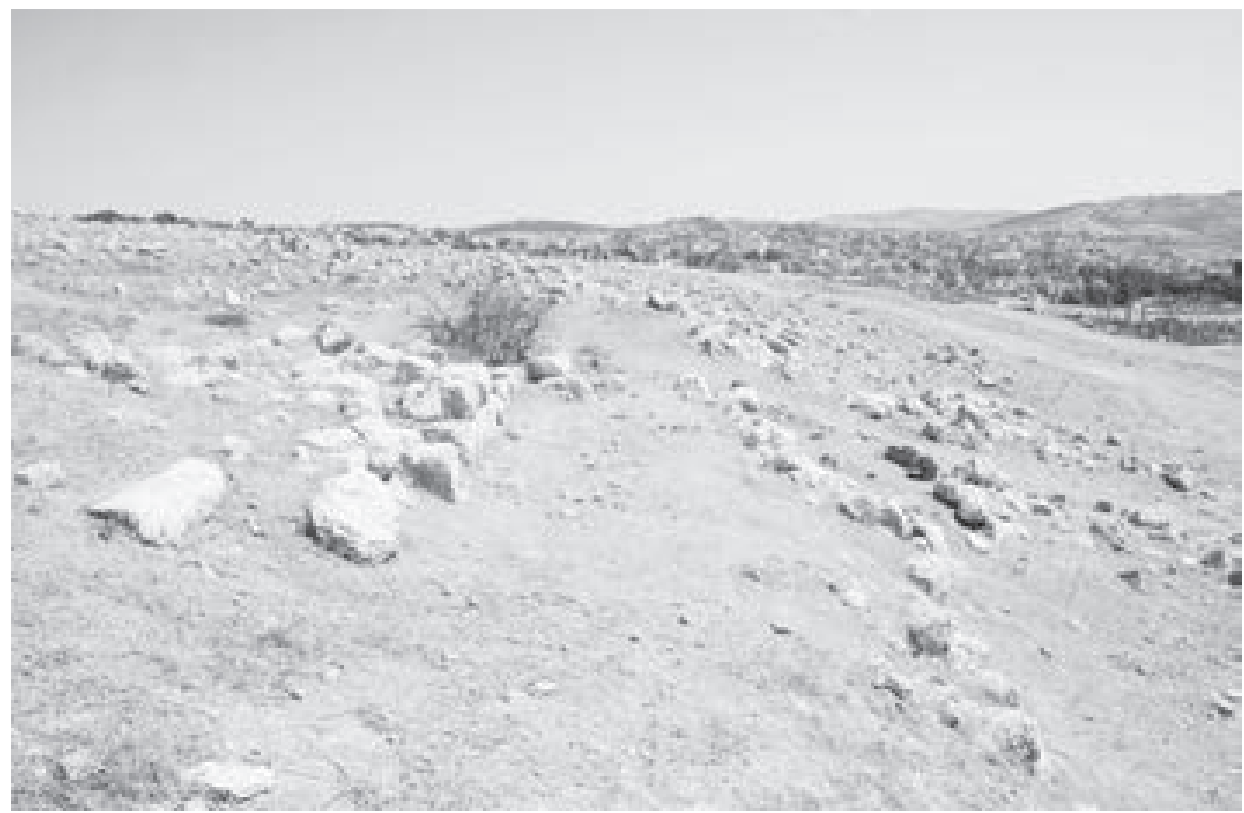

contained remarkable amounts of Roman or even older pottery, attesting to Roman period activities in this area.

The development of the activities in the Northwest Quarter, which we have encountered so far, ranging from surveys of various kinds, geophysical examinations and to excavations, leave the firm impression that the hill was used as a quarry in the Roman period and that noteworthy building activity started from the $3^{\text {rd }}$ century CE onwards. Most building activity seems to have taken place in the late Roman, Byzantine and early Islamic periods as well as the Mamluk period. The early Islamic period has only been shown interest since the early 1980s when among others Gawlikowski excavated a complex of houses on the northern side of the South Decumanus. ${ }^{40}$ Since then Walmsley and his team has undertaken extensive work in other areas mainly focusing on areas around the main street as well as the south-western part of the city. ${ }^{41}$

\section{Trench $K$}

With trench $\mathrm{K}$ the exploration of the so-called East Terrace began (figs. 7 and 22). In this area, densely scattered with stone collapse, only few walls are traceable on the surface but large amounts of architectural elements are visible dispersed across the area. The terrace lies

40. Gawlikowski 1986 for one of the few early Islamic period housing complexes which has been excavated in Jerash until now.

41. See above note 2 as well as Blanke et al. 2007 as well as Walmsley and Damgaard 2005. directly to the west above the Artemision. The trench was laid out half way between the large courtyard further west and the modern dirt road to the east (fig. 22). Since this terrain is scattered with large stones as well as with architectural elements of mostly Roman date, it at first sight gave the impression of being an area heavily disturbed in modern times. Excavation, however, showed that this area had preserved closed contexts from the Umayyad period and that the piles of stones derived from a sudden destruction of the buildings. The sudden destruction can be dated in the 8th century $\mathrm{CE}$ and was probably due to the earthquake of $749 \mathrm{CE}$, which is confirmed through $14 \mathrm{C}$ dating of charcoal from the hearths in the kitchen of the house which was excavated in trench $\mathrm{K} .{ }^{42}$ After the earthquake no rebuilding took place in this area. Trench $\mathrm{K}$ consisted of a total area of $65.9 \mathrm{~m}^{2}$, whereof firstly an eastern square measuring $6,3 \mathrm{~m}$ by $5,3 \mathrm{~m}$ was excavated. This was later extended to the west resulting in a trench $11,2 \mathrm{~m}$ long and $6,5 \mathrm{~m}$ wide. ${ }^{43}$

The building remains excavated in trench $\mathrm{K}$ belonged to a complex orientated along the slope and continuing in northern and southern direction. The building was constructed directly on bedrock, but it seems to have had a relatively short occupation history with only minor changes in its architectural layout, before it was destroyed by the heavy earthquake. The building seems to have been used for domestic purposes and was rich

42. See below notes 48-50.

43. Kalaitzoglou et al. forthc.(c). 


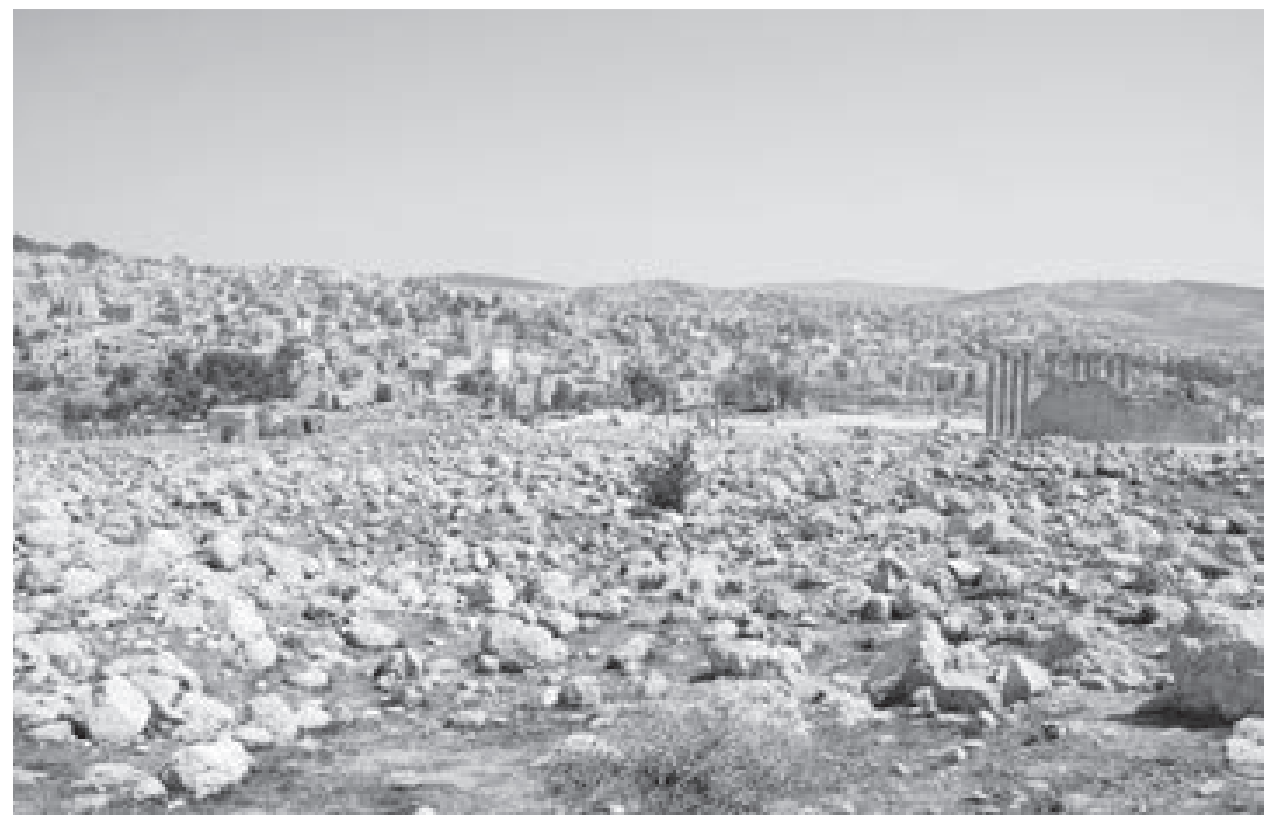

Fig. 21 - General view of the East Terrace, view from west (Danish-German Northwest Quarter Project 2011).

Fig. 22 - Plan (photogrammetric) of trench $K$, find position of coin hoard marked (Danish-German Northwest Quarter Project 2015).

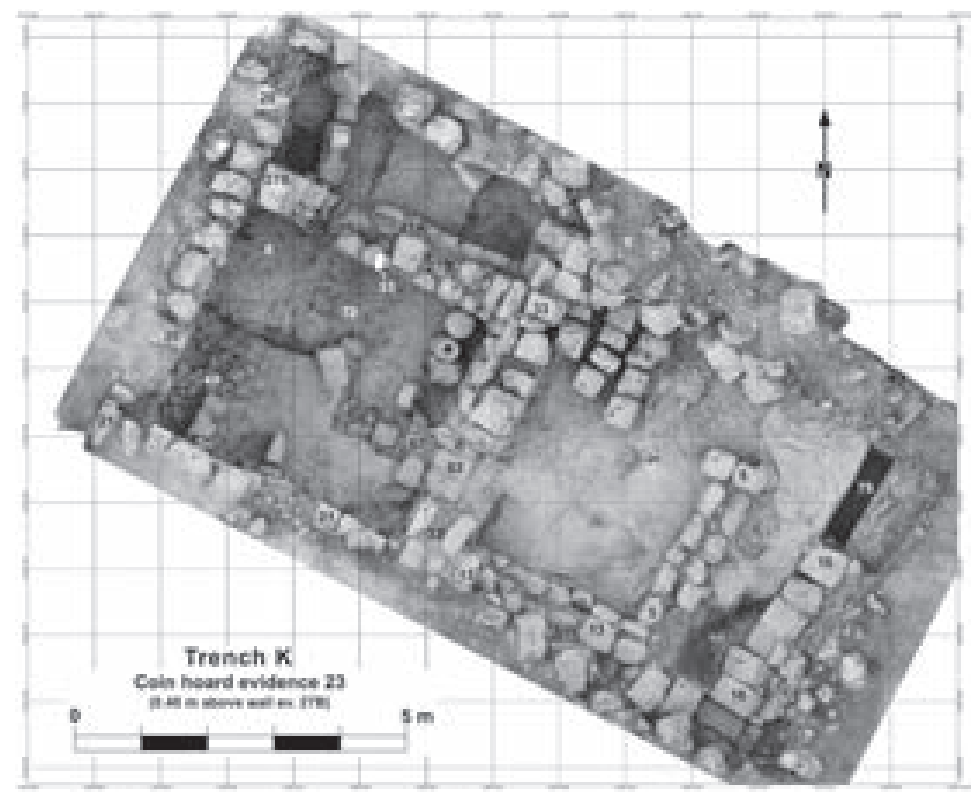

on finds. In the following the excavated parts of the building and its finds will be presented.

Phase 1 (Roman period)

The earliest evidence for human activity is traces of a quarry, discovered in the northwest corner of the trench. Although the unearthed part of the bedrock is limited irregular step-like cuts show that stones of medium size were quarried on this spot (fig. 23). Quarry marks were also discovered in other areas suggesting that large parts of the Northwest Quarter were used as stone quarries.
Phase 2 (Umayyad)

What is traceable from the earliest phase of the house is a large rectangular basement room limited by walls (ev. 20, ev. 21 and ev. 33) (fig. 24). These walls were built on bedrock and the east wall (ev. 33) was built against a step in the bedrock. The room consisted of a north room and a south room divided by an east-west running wall (ev. 27A), which did not reach the west wall (ev. 20) but seems to have left space for a doorway at the western end. The lowest floor found is a thin mortar floor (ev. 72) that was laid over the partly leveled bedrock (ev.6) and the foundation fill (ev. 83) 

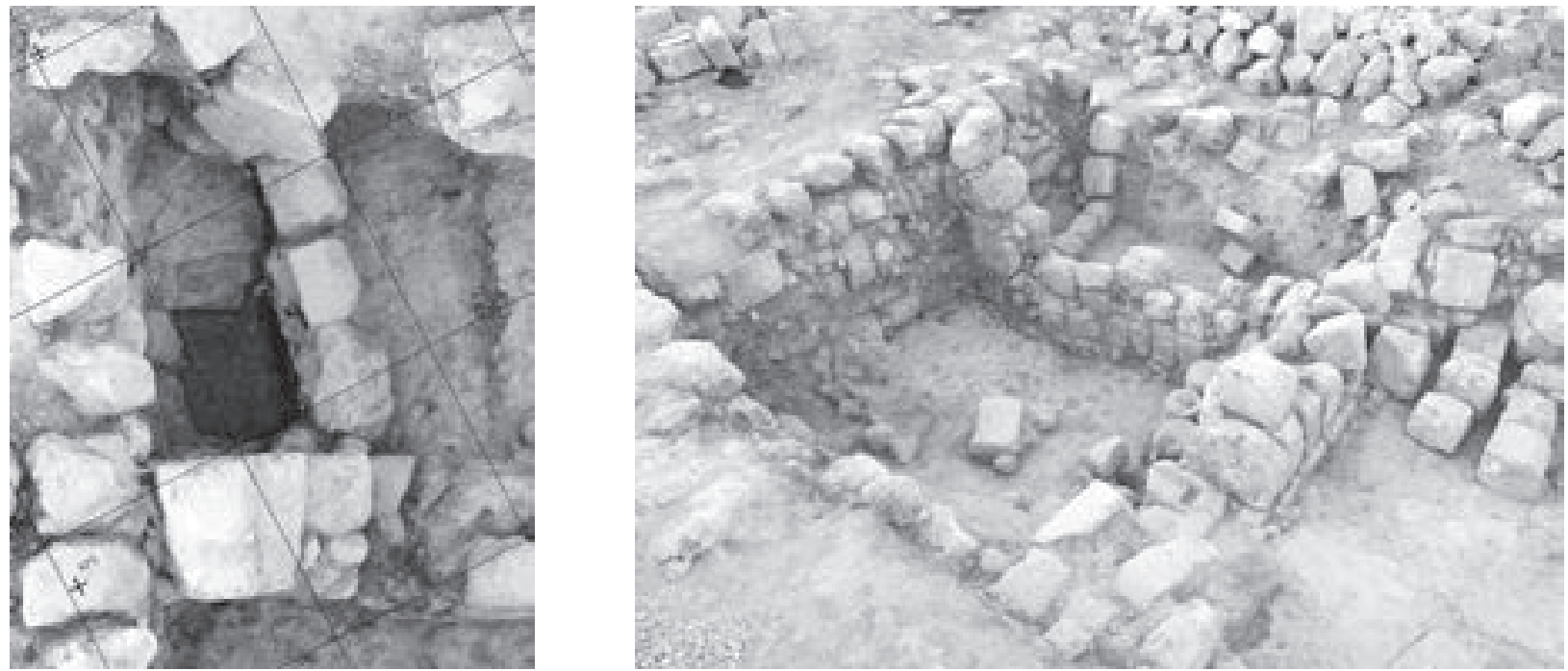

Fig. 23 - Trench K, photogrammetric vertical photo of quarry traces in the northwest corner of the trench (Danish-German Northwest Quarter Project 2014).

(fig. 25). The latter was brought in to fill cracks and lacunae in the bedrock.

East of this building an open plaza was situated on a $0,5 \mathrm{~m}$ to $0,7 \mathrm{~m}$ higher rock surface that was only roughly straightened (fig. 26). At the eastern end of this open space a water channel (ev. 79) was found leading from north to south almost parallel to the building (fig. 27). The channel was cut partly into the rock and partly built against a (natural?) rock edge. It was lined with hard hydraulic mortar. In this phase the open space does not

Fig. 26 - Trench $K$, open area east of the building with younger structures, view from south

(Danish-German Northwest Quarter Project 2014).

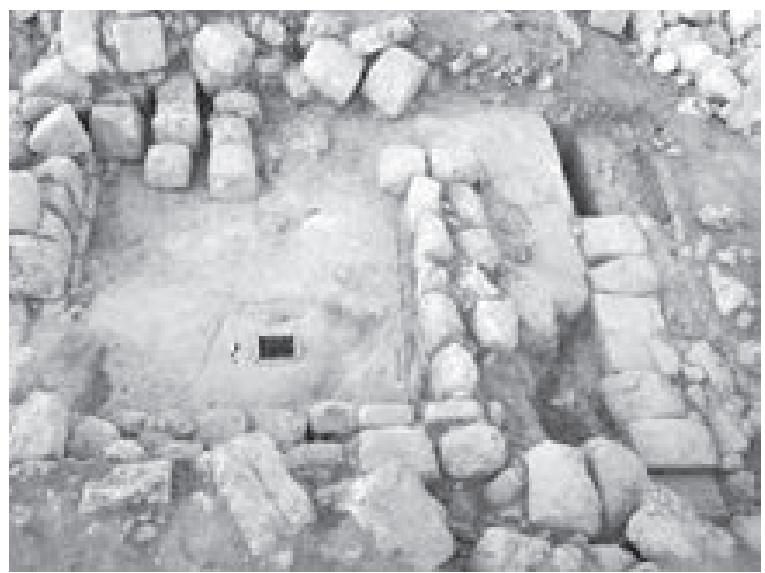

Fig. 24 - Trench $K$, view of the basement room between the walls evidence 20,21 and 33, view from southeast (Danish-German Northwest Quarter Project 2014).

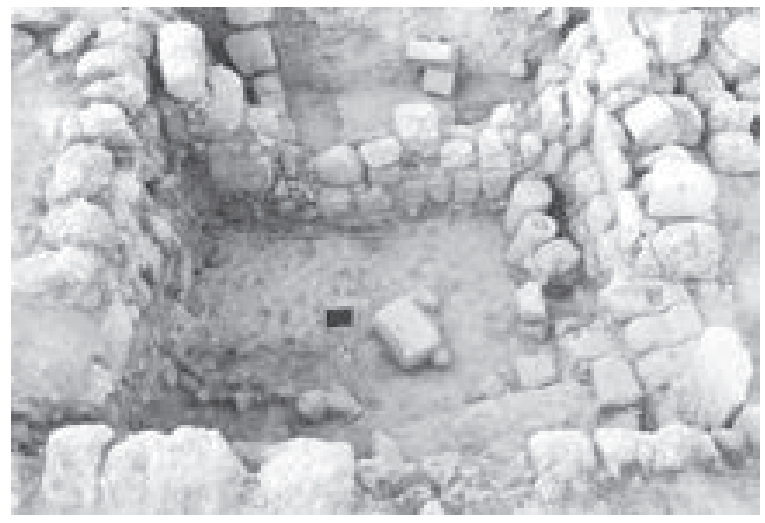

Fig. 25 - Trench K, mortar floor (evidence 72) above the levelled bedrock (evidence 6) in the south room, view from south (Danish-German Northwest Quarter Project 2014).

Fig. 27 -Trench K, water channel lined with hydraulic mortar in at the eastern limit of the trench (Danish-German Northwest Quarter Project 2014).

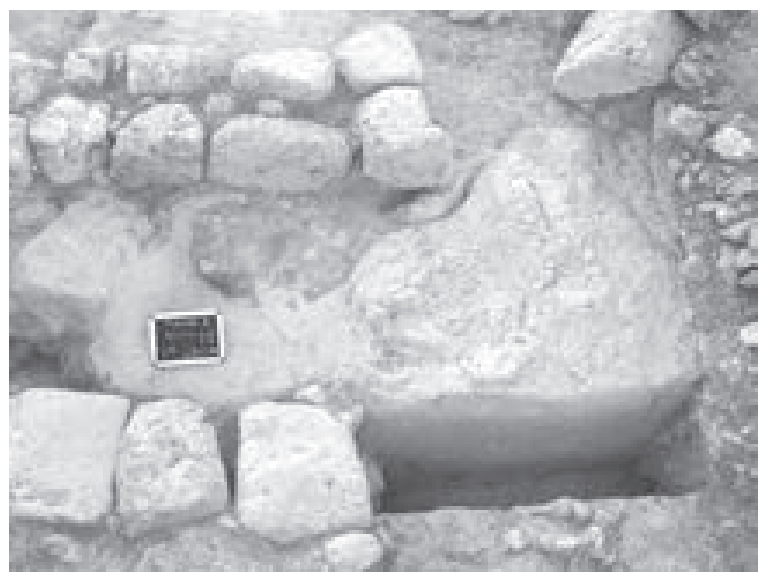


seem to have been accessible from the basement rooms as the door in the east wall was added only later. This suggests that the basement of the edifice in this phase must have been accessible through a door further north beyond the limits of the trench.

\section{Phase 3 (Umayyad)}

In this phase the building was extended to the east, a door was constructed and another room in the courtyard was constructed. This phase is signified by a new clay floor in the south room. In the north room, which was excavated down to bedrock only in its southwestern corner, a corresponding floor was not found. The floor in the southern room of this phase was a simple clay floor (ev. 69, 70, 87, 88), 10 to $15 \mathrm{~cm}$ thick (fig. 28). It was laid above the older floor (ev. 72), which seems to have been damaged and partly removed, especially in the western part. That the new clay floor belongs to the third phase is confirmed by the fact that it runs against the staircase

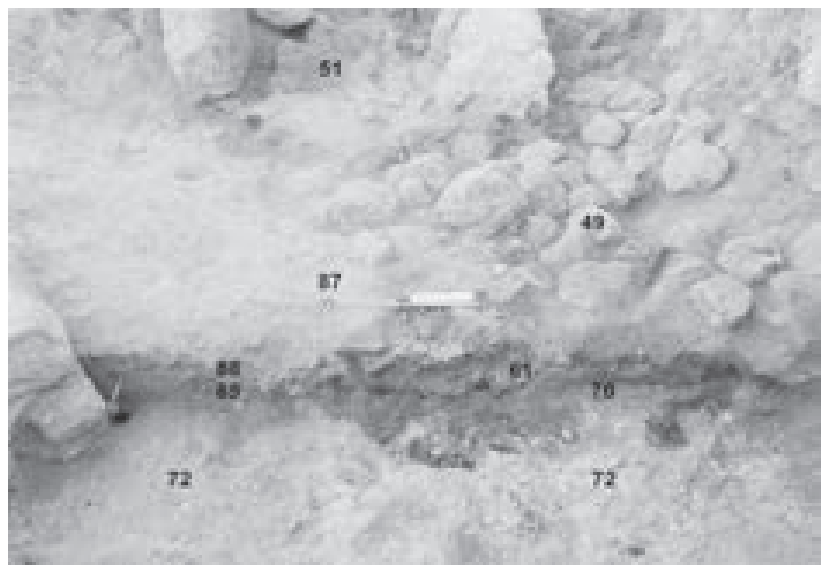

Fig. 28 - Trench $K$ south room, stratigraphic sequence between the mortar floor (evidence 72) and the hearth (evidence 51), view from north (Danish-German Northwest Quarter Project 2014).

Fig. 30 - Trench K, re-used column drums in front of the east wall, view from west (Danish-German Northwest Quarter Project 2014).

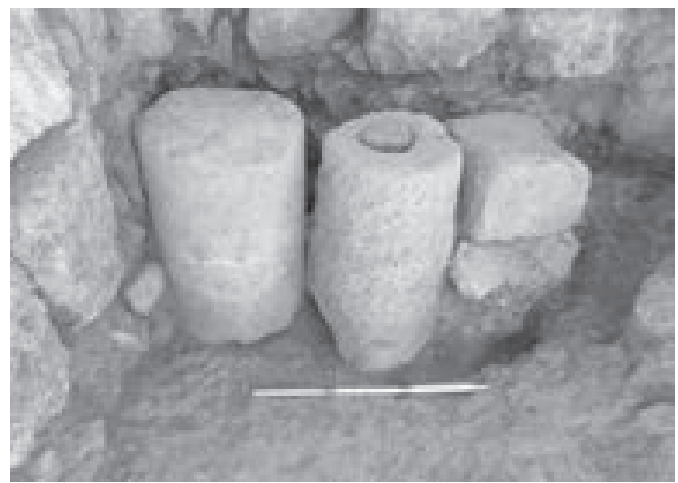

(ev. 67) and under the subsequent ramp (ev. 56), belonging to building phase 4 (see below). This shows that in this phase the southern room was given a door that provided access to the open space to the east. To gain access to the south room a door way (ev. 64) was built into the east wall (ev. 33). That this door was added secondarily is clear through the open wall cores on both sides. Furthermore the threshold (ev. 63) was broken into parts, which were worn, and not in line with the wall but projecting into the room. This underlines the secondary character of the door construction. The staircase (ev. 67) consisted of irregular stones set in a soil and stone foundation loosely against the threshold (fig. 29).

Into the floor of the room an open fire place (ev. 61) was installed near the west wall (ev. 20). In front of the east wall (ev. 33) two low column drums (ev. 41) were found in upright positions (fig. 30). The southern one was hollowed out and a basalt grinder was inside it, so that it was used as a crusher (fig. 31). The installations

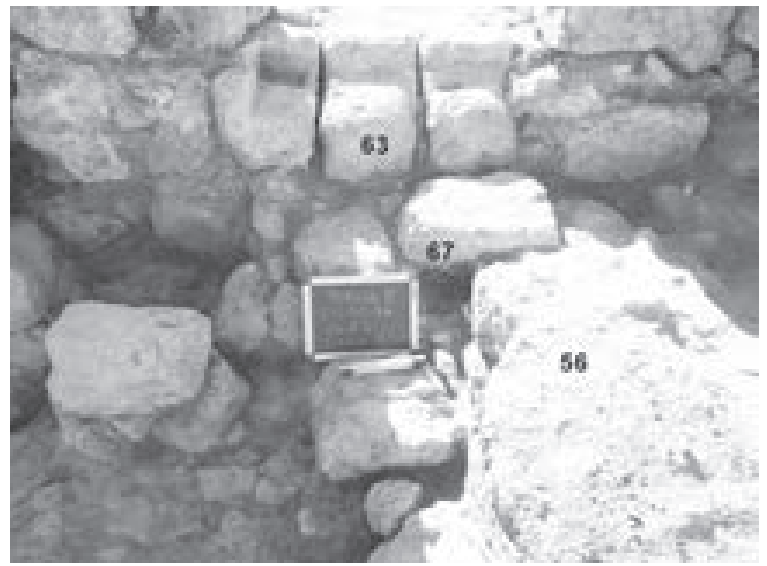

Fig. 29 - Trench $K$, staircase (evidence 67) leading to the open space east of the building, view from west (Danish-German Northwest Quarter Project 2014).

Fig. 31- Trench $K$, a hollowed column drum with a grinder found in it, view from north (Danish-German Northwest Quarter Project 2014).

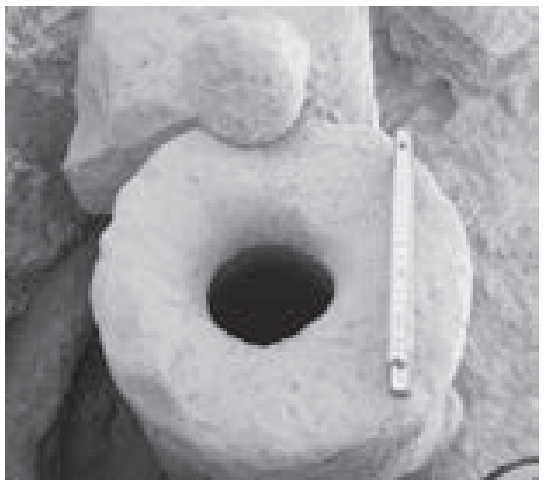


suggest that the southern room was used as a simple working space with an open fire place on the floor.

As a door was installed in this phase leading to the area east of the house, a further room must have been constructed in this phase as well. This east room was located in the open space between the central wall (ev. 33) and the water channel. Its walls (ev. 5, ev. 13) were set against the older edifice on a thin foundation fill (ev. 19 and ev. 43) over the bedrock and a door was built at the east wall (ev. 5). A wall like structure in the east room consisting of three stone rows (ev. 58, ev. 59, ev. 60) and laid parallel to the edifices east wall could belong to a staircase leading up to an upper storey of the house.

\section{Phase 4 (Umayyad)}

The main feature of this building phase is the division of the north room and the south room into two unconnected rooms by a wall (ev. 27B), which closed the opening (ev. 27A). In the north room the northern wall face of the older wall (ev.27A) was kept and a new wall (ev.27B) was built parallel to it separating both rooms. The wall (ev. 27B) was built on a thick foundation fill and in the south room the floor of this phase was raised by a layer of fist and medium sized stones (ev. 49) set into a brownish clay (ev. 48 and 57). This floor completely covered the former fire place (ev. 61) in the south room. On the new floor a simple hearth (ev.51) was built, made of two parallel rows of larger stone slabs (fig. 32). This hearth was found filled with ashes and sherds of a Grey ware vessel. Traces of burning were visible around the area of the south wall (ev. 21). As the floor was much higher, the former staircase was covered and restructured as a simple ramp (ev. 56) consisting of clay and mortar (ev. 47, ev. 52, ev. 71). The column drum installation (ev. 41) remained in place and was integrated into the floor. In consequence

Fig. 32 - Trench K, a simple hearth (evidence 51) in front of the south wall, view from south (Danish-German Northwest Quarter Project 2014).

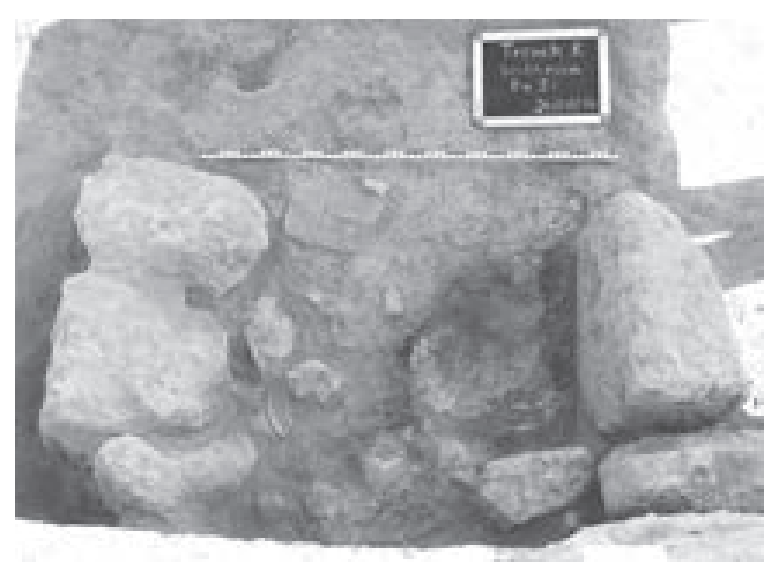

the crusher was no longer functional in this period. In the north room the lower clay floor (ev. 54, ev. 66, ev. 77) was laid on the foundation fill (ev. 68 and ev. 76). As this floor was partly baked and showed traces of a fire, it is suggested that this phase ended up with fire destruction at least in the north room.

\section{Phase 5 (Umayyad)}

During this phase alterations only took place in the north room. The wall (ev. 36) was built on the older floor (ev. 54, ev. 66, ev. 77) to create a low pedestal in front of the west wall (ev. 20). This pedestal covers the bedrock, which was left protruding in the preceding phases. In the rest of the north room a new thin mortar floor (ev. 38) was laid over a thin foundation layer (ev. 55) both running against the new pedestal. In none of the rooms traces of wall plaster were found.

The various phases described above display a strong continuity in the use of the building. No radical alterations were made and nothing suggests that the general nature of use of the building was changed over time. The layout, building technique and architectural features of the building fit well into what is known from early Islamic domestic architecture in the region. ${ }^{44}$ Similar room structures on different levels are well attested from the domestic quarter at the South Decumanus of Jerash as well as from Pella and Beth Shean. ${ }^{45}$

\section{Destruction of the building (749 CE)}

The above described layout was in use when a heavy earthquake destroyed the building. The rooms were filled with between 1,5 $\mathrm{m}$ to 2,0 $\mathrm{m}$ debris (ev. 2) and homogeneous silty clay (ev.3) (fig. 33). The silty clay stems from the pisé walls belonging to the upper stories of the building. In the south room a layer of loose brownish soil (ev. 44) was found under the debris covering the latest floor (ev. 48, 49,57) and the simple hearth construction (ev. 51). Since this layer covers the floor and installations of the last occupation phase, it most likely originated from the ceiling of the basement room with wood and beams. A similar but much thinner layer of loose brownish soil (ev. 35) was found in the north room covering the uppermost floor (ev. 38).

Embedded in the clay and stone collapse (ev. 2 and 3) architectural fittings and some older objects were found (the latter formerly incorporated into the wall cores) as well as a large assemblage of objects which had fallen from an upper storey. Whereas the majority

44. See for example Avni 2014 for one of the most recent overviews; Foote 2000; Gawlikowski 1986; Kennedy 1985 as well as Whitcomb 1992. 45. Tsafrir and Foerster 1997; McNicoll et al. 1982; 1992; Smith 1973. 


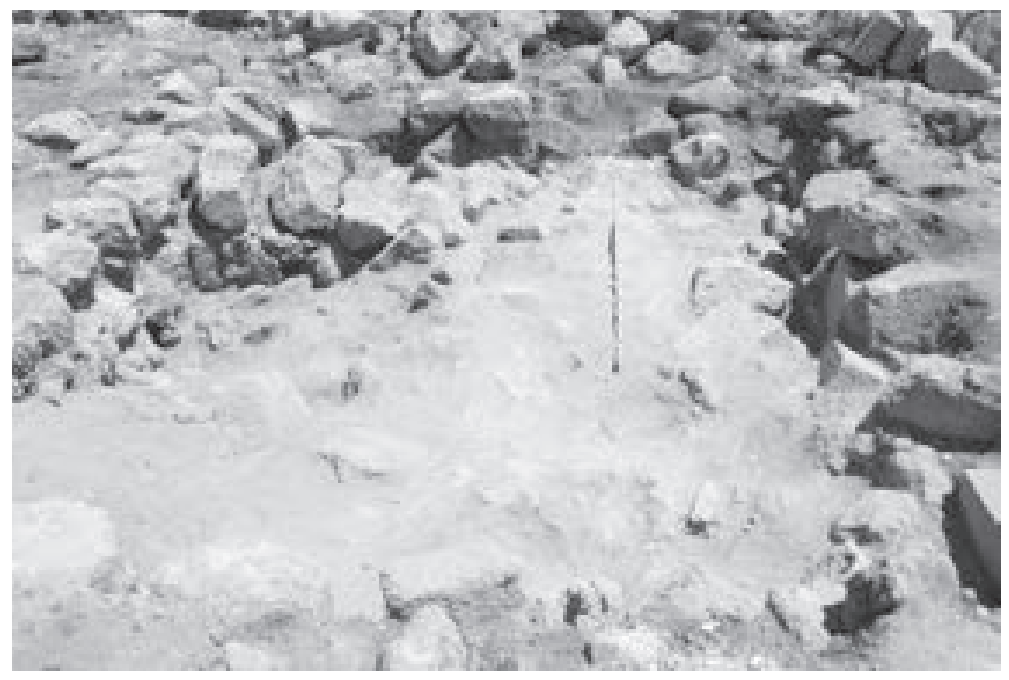

Fig. 33 - Trench $K$, general view of the debris and silty clay (evidences 2 and 3 ) in sectors e to $h$, view from south (Danish-German Northwest Quarter Project 2014).

Fig. 34 - Photo of stucco profile (evidence 39) (Danish-German Northwest Quarter Project 2014).

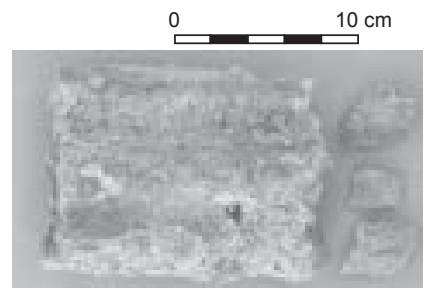

of finds was concentrated in the northern half of the south room between 0,5 and $1,0 \mathrm{~m}$ above the uppermost floor (ev. 48,49,57), some objects were found above the destroyed walls and other structures. Traces of colored wall plaster (in ev. 35) and stucco profile fragments (in ev. 39) (fig. 34) prove that the upper rooms were decorated. In front of the west wall a broken amphora (ev. 32, cat. no. 14) and a Grey ware vessel (ev. 40, cat. no. 15) were found. They had also fallen from the first floor. Two globular glass bottles survived the fall undamaged (cat. nos. 16-17). The most important finds were a coin hoard found in close connection with a metal object (fig. 35) and a mortar with pestle (cat. no. 77), a flax or wool comb (cat. no. 25) and a bronze object (cat. no. 29). ${ }^{46}$ Nearby, at a distance of only $0,4 \mathrm{~m}$, another find cluster (ev. 34) contained iron and bronze objects (cat. nos. 19-22, 27-30, 34-37, 39, $42,44-45,47-54$ ), as well as a bone object (cat. no. 55), spindle whorls (cat. nos. 57-58), an iron lock (cat. no. 29) (probably stemming from a wooden box) and a bronze key (cat. no. 32). At a distance of only $0,35 \mathrm{~m}$ to the west of the coin hoard, a concentration of golden beads (cat. no. 62) and some carnelian beads (cat. nos. 67, 70), a broken glass bottle of the known globular type and a small unguent pot were found (ev. 39) (cat. nos. 18, 10).

The entire area seems to have been abandoned until modern times after the earthquake destruction. No traces of building activities in Ayyubid-Mamluk times were encountered and no agricultural activity seems to have taken place on the East Terrace.
For the dating of the final destruction of the complex we rely on the dating of the finds as well as $14 \mathrm{C}$ datings. The pottery found in all evidences excavated seems to be of Umayyad date. Only small fragments of Jerash bowls were found, which in most cases stemmed from the foundation layers indicating that they relate to the pre-occupation period. Glass lamps with beaded stems, typical for the early Islamic period, were found in the debris as well as three globular glass bottles with short tubular necks typical for the Umayyad period (see above as well as the accompanying catalogue). This evidence suggests both an occupation and destruction of the house in the Umayyad period.

This date is supported by the find coins from the trench. Although analysis of these is not yet completed, it is clear that the latest coins are post-reform coins of the first half of the $8^{\text {th }}$ century CE This evidence supports or at least does not contradict the suggested dating of the destruction of the building in the earthquake of 749 CE Within the destruction layer a small coin hoard was found, as mentioned above. It consisted of 11 coins. ${ }^{47}$ Further four coins might have belonged to the hoard. It contained Byzantine and Arab-Byzantine coins. The earliest coins are dating to the reign of Anastasius I (491-518 CE), the latest from the time of 'Abd al-Malik (685-705 CE). The latest coins stem from the pre-reform period. This is an important observation, since it is generally assumed that with the reform of 'Abd al-Malik completely new coinage was introduced and older coins fell out of use. Until now hardly any coin hoards of this period from controlled excavations have been published 


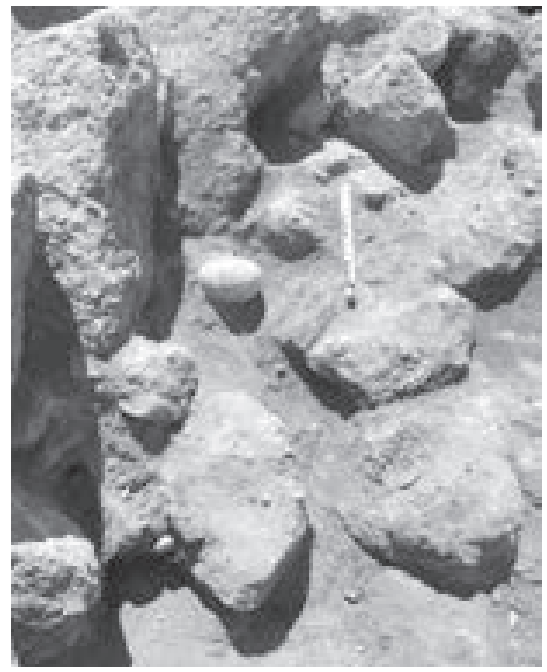

Fig. 35 - Trench $K$ south room, area in which the coin hoard was found, view from southwest (Danish-German Northwest Quarter Project 2014).

and therefore it is difficult to assess the evidence in a broader context. One question for example remains about whether the coin hoard attests to further local use of pre-reform coinage in post-reform Jerash or whether it is simply a collection of coins that fell out of use and were only kept for the value of the metal. Another possibility is that the hoard was assembled and deposited some decennia before the earthquake. Further study of the find coins from the destruction layer will give more data to solve these questions.

A date of the destruction towards the end of the first half of the $8^{\text {th }}$ century CE is furthermore supported by three radiocarbon dates, which in addition show that the edifice was occupied for only two or three generations, before it was destroyed. The sample from the simple fireplace (ev. 61) of the second building phase gives a date between $690 \mathrm{CE}$ and $767 \mathrm{CE}^{48}$ This is almost identical with the date given for the charcoal found and dated in the hearth (ev. 51) built in phase three, since this gives a date between 674 and $764 \mathrm{CE}^{49}$ Also a sample from the lowest part of the debris (ev. 44) covering the latter hearth is dated between 691 and

48. Sample no. 21340 (J14-Kh-61-1), Institut for Fysik og Astronomi, Aarhus University (Denmark), C14 age $1268 \pm 25$ BP, d13C (dual-inlet, olive cores)-22.39 \pm 0.05 , calibration curve IntCal13, $1 \sigma 690-767 \mathrm{CE}$, $2 \sigma 667-775 \mathrm{CE}$

49. Sample no. 21339 (J14-Kh-51-2), Institut for Fysik og Astronomi, Aarhus University (Denmark), C14 age $1294 \pm 25$ BP, d13C (dual-inlet, wood) $-23.30 \pm 0.05$, calibration curve IntCal13, $1 \sigma 674-764 \mathrm{CE}, 2 \sigma 664$ $769 \mathrm{CE}$
$770 \mathrm{CE}$, and thus only slightly younger, proving that the destruction followed relatively soon thereafter. ${ }^{50}$ Since the destruction of the room was devastating and final, it can be assumed that the earthquake of $749 \mathrm{CE}$, which destroyed most of the city, was also responsible for the destruction of this house.

To sum up the chronological evidence, it is likely that the house was built in the early Umayyad period and that it was destroyed in the $749 \mathrm{CE}$ earthquake at the end of the Umayyad period, thus giving us a rarely matched closed Umayyad context with a huge diversity of material culture spanning from the inclusion of Byzantine material to Umayyad period material.

\section{The finds from Trench $\mathrm{K}$ and their implications for understanding of the Umayyad period}

A large number of finds were registered from trench $\mathrm{K}$ amounting to 11,860 objects. Ceramic, including sherds, amounted to 10,651 of these objects. The material from trench $\mathrm{K}$ mainly consisted of material used in cooking installations with associated pottery in the lower levels as well as the material found in the thick homogenous context in the layer above the kitchen fallen from the upper storey of the building. This closed context is of special importance since it belongs as shown above to a destruction phase dating to 749 CE Many finds were well preserved and among these was the Byzantine and Arab-Byzantine coin hoard and also a silver amulet inscribed with pseudo-Arabic script (see below).

The amount of roof tiles located in the trench was low and thus the existence of a tile roof on top of the building is not plausible. The Grey Ware pottery was primarily found in relation to the kitchen installations and was used as cooking vessels. ${ }^{51}$ The use of the Grey Ware as a cooking ware may point to a change in the overall use of this ware during the later Umayyad period, developing from primarily being a storage ware to being used for the preparation of food. ${ }^{52}$ The general appearance of the Grey Ware likewise seems to undergo a development during the later part of the Umayyad period. ${ }^{53} \mathrm{~A}$ new feature within the Grey Ware repertoire is the bi-ansulate cooking pot (cat. no. 13)..$^{54}$

50. Sample no. 21338 (J14-Kg-44-2), Institut for Fysik og Astronomi, Aarhus University (Denmark), C14 age $1259 \pm 25$ BP, d13C (dual-inlet, wood) $-23.26 \pm 0.05$, calibration curve IntCal13, $1 \sigma 691-770 \mathrm{CE}, 2 \sigma 670$ 861 CE (resp. 670-778 CE, 90.6\%).

51. Lichtenberger et al. forthc.(c) for finds relating to Grey Ware.

52. Ibidem.

53. Ibid.; in the North Theatre in Jerash a darker and rougher version of the Grey Ware was likewise observed and termed Ware B (see Clark and Falkner 1986, p. 251).

54. Ibidem, no. 64. Present cat. no. 13. 
The majority of objects was found in the collapse and floor level of the room excavated towards west in evidences 3 and 34. From the upper floor of this house tools connected to textile production were encountered including scissors (cat. no. 24), a heckling comb (cat. no. 25) and spindle whorls of bone, steatite and rock crystal (cat. nos. 57-61) along with jewelry (cat. nos. 62-75) consisting of beads of semi-precious stones, glass and bone. Furthermore a bronze ring with a glass bead was found (cat. no. 76) and parts possibly belonging to a lead mirror frame and a possible bone mirror handle (cat. nos. 40-41, 56). Many of the metal objects were found concentrated within a small area and might have belonged to the content of a wooden box (evidence 34). The lamps from trench $\mathrm{K}$ show late Umayyad to early Abbasid period traits such as the channel nozzle (cat. no. 6), figuratively decorated bases (cat. nos. 7-9) and a hybrid-lamp combining the upper part of a Jerash lamp (however, without the "cross" at the handle) and an Umayyad/Abbasid lamp base (cat. no. 5). The Red Painted Pale Ware and the Yellowish Sandy Ware also point in the direction of a late Umayyad/ early Abbasid type (cat. nos. 1-4, 11-12), suggesting that what we term early Abbasid was in fact well rooted in late Umayyad types and that those features already developed in the late Umayyad period.

A remarkable number of metal objects (cat. nos. 19-54) were found in trench K. Most of the objects are of iron, a smaller number were made of lead and of copper alloy (which includes all kinds of copper base alloys, amongst others bronze). Because of the deteriorated state of preser-

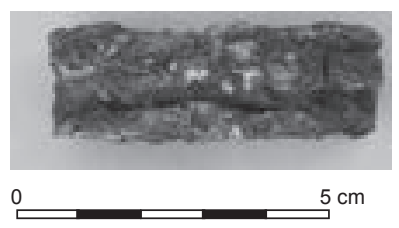

Fig. 36 - Photo of scroll prior to conservation (DanishGerman Northwest Quarter Project 2014). vation in particular of the iron artefacts, it is difficult to determine the exact shape as well as the function of a number of items. A future restoration or X-ray examination might help to interpret these items. However, other objects or fragments are easier to identify as they belong to well-known types. At this stage the metal objects can be divided into several groups: Architectural fittings; Casket fittings and lock; Cosmetic implements; Dress accessories; Horse trappings (?); Household appliance and tools; Locks and keys; Weighing equipment. Furthermore there are objects, which are not clearly assigned to the one or the other group, as well as objects with an unknown function.

\section{Metal amulet}

Within the collapse of the building a $4 \mathrm{~cm}$ broad scroll tightly folded was found. The scroll was encased in a lead tube, which served as an amulet container. The scroll was carefully removed from the container but could not be unfolded without being damaged (figs. $\mathbf{3 8}$ and 39). The metal of the scroll was tested and turned out to be pure silver mixed with a bit of gold, which in ancient terms is called electron. ${ }^{55}$ Since letters of semitic origin could be observed on the scroll, it was decided to conduct computer tomography on the scroll and thereafter try to unfold it digitally, which is a fairly new technique available. Such a procedure demands computer skills, the specially developed software as well as the linguistic/epigraphic knowledge. ${ }^{56}$ The digital unfolding was successful. An Arabic text of 17 lines could be deciphered (figs. $\mathbf{4 0}$ and $\mathbf{4 1}$ ). The reading of the text, however, is still subject to study. Until now it has not

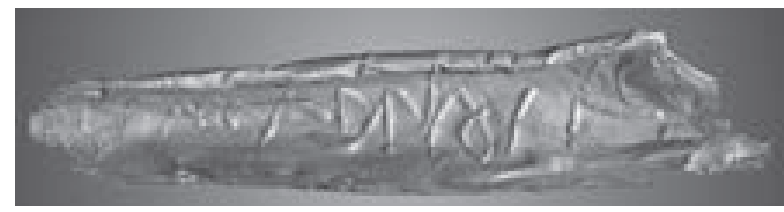

Fig. 38 - Line 1, scroll back side ("Inverted region") (DanishGerman Northwest Quarter Project 2014 and John Møller Larsen).

Fig. 39 - Fig. 41: Line 11, scroll back side (segm. "L11") (DanishGerman Northwest Quarter Project 2014 and John Møller Larsen).

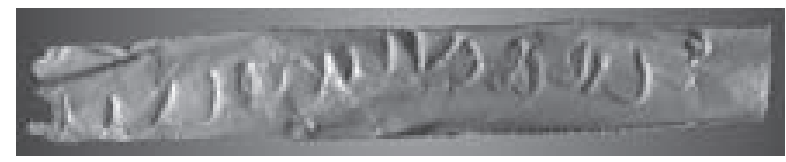

55. Assistant professor Gry H. Barfod, GeoScience, Aarhus University was responsible for the analysis of the metals (Barfod et al. 2015).

56. John Møller Larsen from Aarhus University was trained in this technique and did the digital unfolding of the scroll (Barfod et al. 2015). 
been possible to make sense of the Arabic letters. There is a high probability that we might have to do with a magic Arabic pseudo-script, but it is too early to come to firm conclusions and further study is necessary.

\section{Architectural fittings}

The two objects cat. nos. 19 and 20 are made of copper alloy and have an almost identical shape. They consist of an oblong bar with one rectangular end, while the other end narrows into a little peg and bends up to form a hook. Although they differ in size (length respectively $7,1 \mathrm{~cm}$ and $8,9 \mathrm{~cm}$ ) they belong to the same type of fittings, so-called revetment pegs, which were used to clamp marble slabs to a wall. They are known from Roman-Byzantine contexts, among others from Caesarea Maritima. ${ }^{57}$ Two other objects are of similar shape and have sizes of $7 \mathrm{~cm}$ and almost $10 \mathrm{~cm}$. However, cat. no. 21 is made of iron, which is not common for this type of fittings. All four artefacts were certainly not used as revetment pegs in the building in which they were finally deposited. Their context indicates a secondary usage. They were found located close together along with other objects, which were all probably contained in a box (see below).

\section{Household appliance and tools}

The largest artefact among the objects assigned to "household appliance" is an iron ladle of some $70 \mathrm{~cm}$ length with an oval, plain bowl (cat. no. 23). Similar ladles were found in Olympia, Greece, and were interpreted as coal ladle, which were used to heap up the glowing coal of the cooker. ${ }^{58}$ However, such ladles may also have been used for textile production processes in particular softening fibres and dying textile, which included the submersion of textiles in fluid and a substantial amount of stirring was required. Scissors, knives, and different sized sewing needles were in stock in every household. However, large iron scissors like the fragments cat. nos. 24 with a total length of 31 $\mathrm{cm}$ are much bigger than what one would expect for daily life use. Scissors of this size were rather used for agricultural or manufacturing activities, especially for sheep-shearing. Another find has yielded even more evidence for textile production activities. Although broken in many fragments, object cat. no. 25 can be identified as a wool or flax comb or heckling comb through its typical feature with two rows of long, needleshaped teeth. This instrument is used to remove the fibrous core and impurities from flax and to arrange the

57. Patrich 2008, pp. 441 and 456, no. 101-107; Waldbaum 1983, pp. 6667; pl. 19.266-277.

58. Waldbaum 1983, p. 60; pl. 16.220-221; Baitinger, Völling 2007, p. 92; pl. 31.376 . fibres of wool prior to further treatment. A good parallel to such a wool comb was found in Pergamon, Turkey. ${ }^{59}$

\section{Locks and keys}

Beside the casket's lock (see below) three items have been found belonging to locks and keys. This is not unusual for the spectrum of household findings. Circular keyhole plates of copper alloy like cat. no. 31 are also known from Sardis, Turkey, Olympia and Isthmia, both Greece, and thought to be of Byzantine and Late Byzantine date..$^{60}$ They cover rotary locks, which were closed and opened by rotary keys. In fact, the 2014 campaign yielded one exemplar of this sort of key: the key with ring cat. no. 32, which can be dated in the same period. ${ }^{61}$ Typical for Byzantine times are the dolphin shaped ends of the ring. In contrast to this sort of key, item cat. no. 33 is a big slide key, which was created for a tumbler lock like the probable casket lock cat. no. 29 and cat. no. 30. slide keys are a standard form in Roman times, but appear in even larger amounts throughout Late Antiquity.

\section{Weighing equipment}

The most striking evidence for weight equipment in the excavation area of the 2014 campaign is the flat square of a commercial weight (cat. no. 37). The incised Greek letters Gamma and Alpha indicate a standard weight of one ounce, ca. $27 \mathrm{~g}$. The square type is one of three different shaped Byzantine weights and was the leading type in the Byzantine and Late Byzantine period. ${ }^{62}$ It is not clear whether this was still in use in the mid-eighth century CE or whether it was kept for its metal value. Two other items are components of balances: the suspensions cat. nos. 38 and 39. They belong to rather small and slender balances with a horizontal beam and a movable suspension with two long legs, which are attached to the centre of the beam. Complete preserved examples of this type of balances were found in the Byzantine shops of Sardis, Turkey, which were destroyed in the early $7^{\text {th }}$ century CE, perhaps during a Persian attack in $616 \mathrm{CE}^{63}$

\section{Horse trappings (?)}

There is no clear evidence for horse trappings. However, two items might be assigned to such a specified use. The iron buckle cat. no. 45 has a pivot-mounted axis which is quite unusual for belt buckles of Byzantine and Late Byzantine period. ${ }^{64}$ Buckles of this kind were rather

59. Gaitzsch 2005, p. 42; pl. 58, 75, 1-2.

60. Waldbaum 1983, pp.72-73; pl. 24.385; Baitinger, Völling 2007, pp. 138-142; pl. 56.634; Jantzen 2004, pl. 32.1184.

61. Patrich 2008 , p. $422 ; 428$, no. 16 ; Waldbaum 1983, p. 76 ; pl. 25 , no. 403-407; Jantzen 2004; pl. 33, no. 1189.

62. Patrich 2008, pp. 422; 428; no. 16; Waldbaum 1983, p. 76; pl. 25.403407; Jantzen 2004; pl. 33.1189.

63. Wamser 2004, pp. 362-363; Bendall 1996, pp. 29-38.

64. Waldbaum 1983, pp. 82-84; pl. 29.448 and 460. 
used for saddle girth or other parts of horse harnesses ${ }^{65} \mathrm{~A}$ related item is the fragment with missing axis cat. no. 46, made of copper alloy. Quite similar buckles are dated to the sixth - seventh centuries CE and were only used as belt buckles on rare occasions. ${ }^{66}$

\section{Cosmetic implements}

There are some cosmetic implements among the metal objects of the 2014 campaign, while pieces of jewellery are largely absent (just one finger ring and beads of e.g. gold, carnelian, and glass have been found (cat. nos. 62-76). Cat. nos. 40-41 are fragments of an open-work, wheel-like frame made of lead. Yet, it is not clear if all fragments stem from one single frame. They were very probably part of a now lost glass mirror, which was attached to the frame. Parallels of open work lead frames were uncovered in Caesarea Maritima, but the precise function of the Caesarea pieces is unclear. ${ }^{67}$ They span a wide chronological range, from the Byzantine to the Crusader period. However, lead mirror frames are usually known from Roman and Byzantine contexts. Finally, a lid made of copper alloy, cat. no. 42 , is assigned to the cosmetic implements, because it might have been part of a needle or kohl tube.

\section{Dress accessories}

One model for ans one strap end of belt sets, cat. nos. 43-44, were also found. Both can be dated to the Late Byzantine period. ${ }^{68}$ The decorated strap end no. 43 deserves special attention. It served as a model for a strap end of a composite belt; a special belt type which came into fashion in the Byzantine world and surrounding regions from the mid-sixth century $\mathrm{CE}$ onwards. The stylized vegetable ornament of cat. 43 is typical for a series of belt plates, which are well known from Langobardic Italy, although the ornament style is clearly Byzantine. ${ }^{69}$ However, up to now there is only little evidence for such belt plates in the Near Eastern provinces and this piece is one of the few found in the region, and probably attest to production of such belts in Jerash.

\section{Casket fittings and lock}

Some 30 metal objects were found close together, some of them were even linked together by corrosion processes. This feature is interpreted as having belonged to a wooden box and the objects representing its contents. Among the metal finds are several items which could be fittings of the box like the hinge cat. no. 34. Furthermore, fragments of a probable

\footnotetext{
65. Jantzen 2004, pl. 20, no. 748; similar buckles of copper alloy, but just with one pivoted axis: Patrich 2008, p. 458, nos. 211-212.

66. Vida 2009 , pp. 249-251.

67. Patrich 2008, pp. 425; 430, nos. 73-79.

68. Schulze-Dörrlamm 2009, pp. 268-270.

69. Ibidem.
}

tumbler lock and its closing device were also discovered cat. nos. 29-30. The reconstruction of the box, however, still remains to be undertaken. Issues about the function of the box remain open and therefore a contextualized interpretation of its content cannot be given. However, there are indications that it partly held scrap metal which was kept for the sheer value of the metal and not because the objects were in use. The objects stemming from the box included weighing instruments as well as tools and dress accessories. None of the objects seem to have been complete or belonged to a complete unit, which supports such an interpretation. A single weight and just one suspension of a balance/scale, a single strap end, and even more astonishingly some revetment pegs (see above) originating from monumental buildings formed part of the ensemble. The artefacts rather give the impression of being a collection of recycled minor metal objects than a box of useful instruments for household and/or handicrafts purposes.

\section{Finds relating to textile production/ linen production in Jerash}

In total 10 objects found in Trench $\mathrm{K}$ can be related directly to textiles and textile production processes. These include:

- a pair of sheep shearing scissors (cat. no. 24)

- a wool comb or heckling comb for flax (cat. no. 25)

- a large ladle (cat. no. 23)

- two needles (cat. nos. 26-27)

- five spindle whorls (cat. nos. 57-61)

Although not overwhelming in a trench yielding so rich finds, these objects are significant, since they are found in a contextualized context along so many other finds which allow us an overview of at least parts of a domestic household assemblage. The focus on textile production and not only spinning itself, but also the earlier stages such as sheering as well as possibly dying or working fibres for textile production, indicate that such processes did not only take place outside of domestic contexts but may also have taken place in either domestic contexts or possibly in communal settings in which the co-producer brought his/her own tools to a place where various stages in the production process could take place.

Other places in the Decapolis region were renowned for their textile production, among these was Scythopolis. The Price Edict of Diocletian mentions textile from Scythopolis as some of the most expensive textiles in the Roman Empire in the $4^{\text {th }}$ century $\mathrm{CE}^{70}$ Producers of textile

70. Price edict of Diocletian 26-28. Lauffer (dir.) 1971, pp. 328, 351 s.v. Scythopolitanus and Skythopolitanos. See also for textiles in 
in Scythopolis were according to the edict authorized to ask the highest price for tunics and other cloth made of linen. The edict mentions other kinds of garments (more than a dozen) for men, women and children. These are rated according to various quality grades. Textiles from Gerasa do not appear in the edict. However, Gerasa offers evidence from the Roman period for the importance of linen production in the city in a context, which underlines that linen manufacturing held a central role in Gerasene society at least in the late Roman period. An inscription dating to the $3^{\text {rd }}$ century CE situated on the front row benches in the North Theatre speaks of the group of the linen workers. ${ }^{71}$ These were seated prominently in the first row of the North Theatre in this period along with other phylai. However, the linen workers, who in fact must have been a group of elite owners of manufacturing places, remain the only group of professionals, which are represented in the inscriptions of the North Theatre. This attests to the importance of this handicraft in $3^{\text {rd }}$ century $\mathrm{CE}$ Gerasa. Linen production involved extensive use of water, such as flax and linen production and Gerasa's location on the Chrysorrhoas, the so-called Golden River, would have facilitated this métier greatly. ${ }^{72}$

Although from a later period the objects from the domestic Umayyad context on the East Terrace calls to mind the importance of textile production, which continued well into the early Islamic period. Furthermore the finds remind us that such undertakings may have been a collaborative initiative between several families and may not always have been purely based on a workshop model as is often assumed. Needless to say much remains to be proven but the finds from the domestic context from the early Islamic period, will allow for further insight.

\section{Conclusion}

The domestic complex of the Umayyad period excavated in parts in the 2014 campaign of the DanishGerman Northwest Quarter project gives us the

\footnotetext{
Scythopolis: Expositio totius mundi et gentium 30-31 and the Rabbinic sources yQid II,5-62c, yAZ I,2-39c as well as CTh 10,20,8.

71. Retzleff, Mjely 2004, in particular pp. 39-40.

72. Lichtenberger, Raja 2016a for a survey of the sources and uses of water in Gerasa.
}

opportunity to gain more knowledge about domestic contexts in this period. Together with evidence to be published from the Scythopolis excavations pertaining to commercial activities as well as the results of the excavations of the Islamic period shops on the main street in Jerash this house and its inventory provide one of the most enlightening recent finds. ${ }^{73}$ Since the context is undisturbed and well dated, important observations on the typology and chronology of central groups of material culture can be gained. This closed context provides insight into the contemporary spectrum of material culture in the Umayyad period. Unfortunately in Jerash such closed undisturbed contexts are rare and therefore this complex adds needed data on the chronology and typology of early Islamic material culture. The objects from this trench provide well-dated reference points for the Umayyad period. Another important result is also a more differentiated picture of the continuity and transformation of material culture from the Byzantine into the early Islamic period as well as tracing features usually termed as Abbasid already in the Umayyad period.

Also relevant are the objects related to textile production from the house. Although it is clear that textile production did not take place on an industrial scale in this house and that this building is not related to the Roman linen workers mentioned in the North Theatre of Jerash, it adds information to decentralized small scale textile production in the Umayyad period.

The development of the Northwest Quarter in general indicates that the Byzantine and early Islamic periods were the most prosperous ones in this area and that the hill in earlier times was used as a quarry. Only from the $3^{\text {rd }}$ century CE onwards did building activity truly take off in this area. The location of the Northwest Quarter - high above the city, the highest point within the city walls and firmly bound into the water supply of the city - must have made this area attractive in the Byzantine and early Islamic periods, when other areas of the city were already clustered with monuments and buildings of earlier periods.

The Danish-German Jerash Northwest Quarter Project

73. Tsafrir, Foerster 1997. 


\section{Pottery - Fine ware}

\section{Red Painted Pale Ware}

1. J14-Kh-3-549

Bowl rim, fragmented.

Diam.: 11;

H.: 3,3 ;

L.: 3,3 ;

T.: 0,4 .

Munsell: core: (inner): 7,5YR 6/4; (outer): 7,5YR 7/4; int.: 7,5YR 6/4; ext.: 10YR 7/2; deco.: 2,5YR 5/4

Hard fired and medium finely levigated clay, including a few air pockets. Wheel-made rim fragment with red painted deco. on ext.: two thick, diagonal lines.

References - deco.: Walker 2012, p.517; fig.4.4, no. 20; pp. 510-511; fig. 4.1, no. 27; fig. 4.2, no. 1; Rasson, Seigne

\section{J14-Kh-44-25}

Bowl rim, fragmented.

Diam.: 10;

H.: 2,9;

L.: 2,8

T.: 0,3 .

Munsell: core: 7,5YR 6/4; int.: 7,5YR 6/4; ext.: 10YR 7/4; deco.: 10YR 4/3.

Bowl, hard fired and rather finely levigated clay, including a few air pockets. Flattened rim fragment with red painted zig-zag lines.

References - deco.: Walker 2012, p.517; fig. 4.4, no. 20; Najjar 1989, p. 312, fig. 5, no. 4; Rasson, Seigne 1989, p. 127, no. 7; fig. 5, 5; Walmsley et al. 1993, p. 213 Ware 2; p. 215; fig. 23, no. 3-4.

3. J14-Kh-3-439

Bowl rim, fragmented.

Diam.: 10,6;

H.: 4,25 ;

L.: 4,8 ;

T. (min.): 0,3 ;

T. (max.): 0,7 .

Munsell: core (inner): 10YR 7/4; (outer): 7,5YR 7/6; int.: 7,5YR 7/4; ext.: 7,5YR 7/6; deco.: 10R 4/4; wash: white $2,5 \mathrm{Y}-/ 18 /$

Crispy fired, medium finely levigated clay, including some air pockets, many lime (a few erupted) and many brown spots. The thin, matt and worn red paint is put onto a matt and worn white wash which is covering the surface.

\footnotetext{
* Abbreviations: - AE: copper-alloy ('bronze'). - D.: depth. - Diam.: diameter (in cm). - ext.: exterior. - FE: iron. - H.: height. - int.: interior. - L.: length. - PB: lead. - T.: thickness. - W.: width. - Wt.: weight (in g). Drawings prepared for publication by Janek Sundahl.
}

1989, p.127, no. 7; fig. 5, 5; Najjar 1989, p. 314, fig. 5 , no. 4; 'Amr 1988, fig. 1, no. 7, 11; Walmsley et al. 1993, p. 213, Ware II; p. 215; fig. 23, no. 3-4.

References - shape: Gawlikowski and Musa 1986, p.12, second top on right column; Walker 2012, p. 512; fig. 4.1, no. 13-18; Walmsley et al. 1993, p. 213, Ware 2; p. 215; fig. 23, no. 3-4; Lichtenberger et al. forthc.(c), no. 12. Umayyad $\left(7^{\text {th }}-8^{\text {th }}\right.$ C. AD.

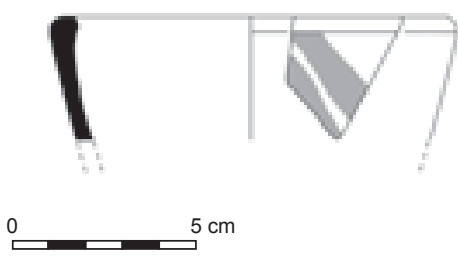

References - shape: Walker 2012, p.512, no.13-16; fig. 4.1; Gawlikowski and Musa 1986, pl.12, second top on right column; Walmsley et al. 1993, p.213, Ware 2; p.215, no. 3-4; fig. 23; Lichtenberger et al. forthc.(c), no. 13.

Umayyad $-8^{\text {th }} 9^{\text {th }}$ C. AD.

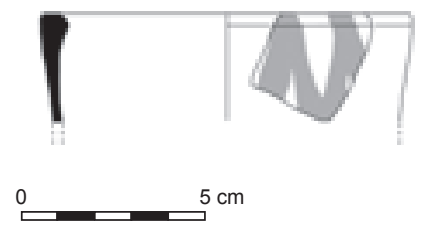

References - deco.: Walker 2012, p.517; fig.4.4, no.20; pp. 510-511; fig. 4.1, no. 27; fig. 4.2, no. 1; Rasson, Seigne 1989, p.127, no.7; fig.5, no. 5; Najjar 1989, p. 312, fig. 5, 4; 'Amr 1988, pp.247-254; fig. 1, no. 7, 11; Walmsley et al. 1993, p. 213, Ware 2; p. 215 no. 3-4; fig. 23.

References - shape: Walker 2012, p. 512; fig. 4.1, no. 13-16; Gawlikowski, Musa 1986, pl.12, top on right column; Walmsley et al. 1993, p. 213, Ware 2; p. 215, no. 3-4; fig. 23; Lichtenberger et al. forthc.(c), no. 14. Umayyad $-8^{\text {th }}-9^{\text {th }}$ C. AD.

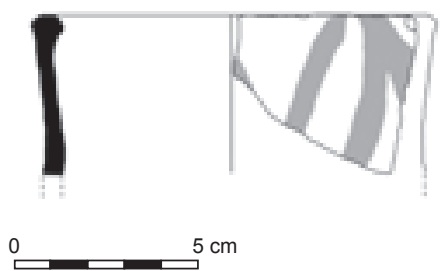


4. J14-Kh-3-548 + J14-Kh-3-544

Jar, body.

Diam.: 2,8; H.: 5,4; L.:12,2; T.: 0,8

Munsell: core: (inner): 5YR 7/1; (outer): 5 YR 7/6; int.: 7,5YR 7/4; ext.: 10YR 8/2; deco.: 2,5YR 5/6.

Pear-shaped jar. Hard fired and rather finely levigated clay, including a few air pockets. Thin whitish slip; deco.: two red horizontal lines, two wavy lines below and remains of another red paint above.
References - deco.: Walker 2012, p. 517; fig. 4.5, no. 1; Smith 1973, pl. 91, C; Lichtenberger et al. forthc.(c), no. 18.

References - shape: Walker 2012, p.517; fig. 4.4, no. 22; Schaefer, Falkner 1986, p. 314; fig. 13, 7.

Umayyad $-8^{\text {th }}-9^{\text {th }}$ C. AD.
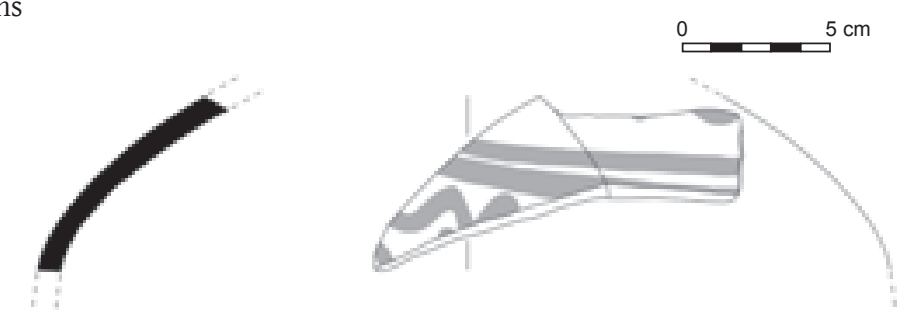

\section{Lamps}

5. J14-Kc-3-202

Jerash lamp, intact.
H.: 6,6;
L.: 9,4; T.: 0,6.

Munsell: core: Gley 1 2,5/10/4; surface (int.): Gley $14 / \mathrm{N}$; (ext.): Gley $14 / \mathrm{N}$.

Mould made with a wavy ledge on upper surface; continuous diagonal lines running around edge of body, round filling hole. Above wick hole a vertical line is flanked with volutes and two circles; two ledges around the filling hole; straight zoomorphic handle and oval base ring; diagonal lines running on ring base; inside base ring, deco.: bird and star.

References: al-Khouly 2001, fig. 4, no. 196; Khairy, 'Amr 1986, fig. 12, 15; Day 1942, pl.12; Lichtenberger et al. forthc.(c), no. 33.

Late Byzantine - Umayyad.

6. J14-Kc-3-152

Rim, fragmented.

H.: 1 ; L.: 4,6;

T.: 0,55 .

Munsell:

core: 2,5 YR 6/8;

surface (int.): 2,5 YR 6/8;

(ext.): 5 YR 6/6.

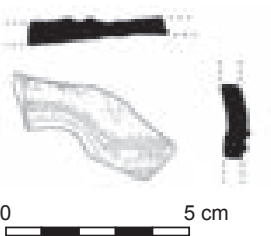

Mould made, channel nozzle lamp; deco.: stars on upper side; diagonal lines on top of channel nozzle; Ledge running around filling hole.

References: al-Khouly 2001, fig. 1, no. 196; Khairy, 'Amr 1986, fig. 9; Lichtenberger et al. forthc.(c), no. 36. Umayyad ( $7^{\text {th- }} 8^{\text {th }}$ C. A.D.).
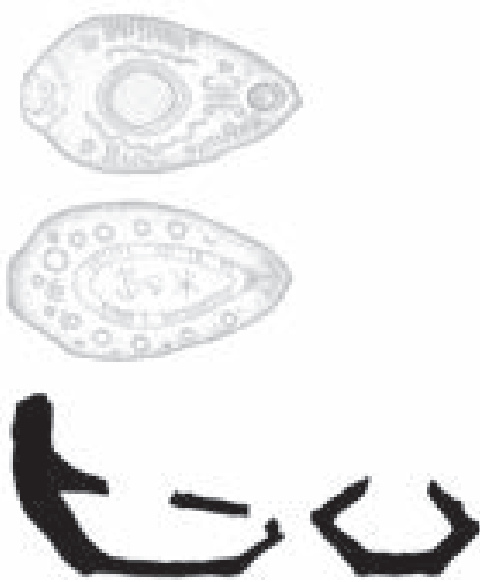

\section{J14-Kac-3-81}

Complete base.
H.: 1,8 ;
L.: 9,2;

T. (max.): 0,95; T. (min.): 0,15;

W.: 5,27.

Munsell: core: 5YR 5/4; surface (int.): 10YR 3/1; (ext.): 2,5YR 5/6.

Mould made, drop shaped base; inside the drop shaped stand ring leaf deco; diagonal lines running around stand ring; stars and Greek letters [N X] on upper side of base. Int. traces of use and fingerprints.

References: Khairy, 'Amr 1986, fig. 10; Lichtenberger et al. forthc.(c), no. 40.

Umayyad (7th-8th c. A.D.). 
8. J14-Kc-3-20+26+66

Base, fragmented.

H.: 1,5 ;

L.: 5 ;

W.: 5,7 .

Munsell:

core: 2,5 YR $6 / 8$;

surface (int.): 5 YR $7 / 8$;

(ext.): 5 YR 6/6-5YR 6/3.

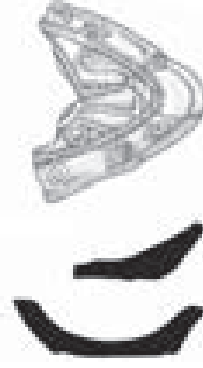

Mould made; deco.: vase like depiction in base ring; around edge of base: stars, leaves and circles.

References: al-Khouly 2001, fig. 4, no. 196; Khairy, 'Amr 1986, fig. 12, 15; Lichtenberger et al. forthc.(c), no. 41.

Umayyad ( $7^{\text {th }}-8^{\text {th }}$ C. A.D.).

9. J14-Kg-44s-12

Base, fragmented.

H.: 2,2;

L.: 4,5 ;

T.: 0,7 .

Munsell:

core: 2,5YR 6/6-6/8;

surface (int.): 2,5YR 7/6-6/6;

(ext.): 5YR 6/6.

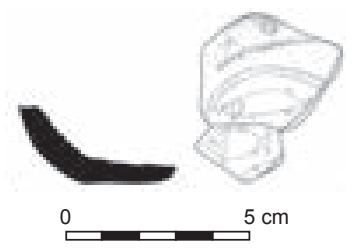

Mould made; deco.: at base centre two complete fish and parts of a third fish; one star and one circle on upper base part.

References: Khairy, 'Amr 1986, pl. 41, fig. 15; Day 1942, pl. 65, fig. 1; Lichtenberger et al. forthc.(c), no. 42.

Umayyad $\left(7^{\text {th }}-8^{\text {th }}\right.$ C. A.D. $)$

\section{Household vessels}

10. J14-Kg-39-1

Juglet, almost intact.

Diam. (base): 3,3;

Diam. (max.): 5,2;

H.: 5,5 ;

L.: 5,2 ;

T.: 0,4 .

Munsell: Ext.: 7,5YR 4/3; core: 7,5YR 5/4.

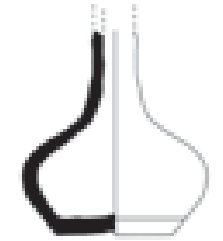

$5 \mathrm{~cm}$

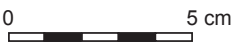

Yellowish Sandy Ware

11. J14-Kc-3-154

Jug rim, fragmented.

Diam.: 4,8 ;

H.: 3,44 ;

L.: 3,93 ;

T. (min.): 0,36;

T. $(\max ): 0,$.

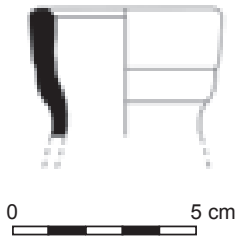

Munsell: ext.: White 2,5Y-/2 8.5/; int.: White 2,5Y-/2 8.5/; core: 5 Y $8 / 4$.

Jug with rounded rim, straightened neck. Soft fired. Levigation: medium, some air pockets; inclusions: some tiny stone grits, and black spots.

References: Lichtenberger et al. forthc.(c), no. 52. Not datable.
12. J14-Kc-3-63

Jug rim, fragmented.

Diam.: 10;

H.: 4,3;

L.: 6,5;

T. (rim): 0,47;

T. (body): 0,45.

Munsell: ext.: 2,5YR 8/2; int.: 5Y 8/2; core: 2,5YR 8/2.

Jug with rounded rim and straightened neck. Two broad and shallow ribs circulating the neck. Slimmer and even shallower ribs at shoulder. Soft fired. Levigation: medium with air pockets; inclusions: a few lime,
Straightened, elongated neck; compressed, globular body; disk base. No handle attachment visible. finely with ir pockts; inclusions: some lime, many erupted, some black and red-brown spots.

References: Lichtenberger et al. forthc.(c), no. 55.

Not datable. 


\section{Cooking vessel - Grey Ware}

13. J14-Kh-3-444

Cooking pot, almost intact.

Diam.: 7,6;

H.: 13,4 ;

T. (min.): 0,22 ;

T. (max.): 0,64.

Munsell: core: (inner): 7,5YR 5/2; (outer): 7,5YR 6/1; surface (ext.): 2,5Y 2.5/1; (int.): 2,5Y 5/1.

Rounded, thickened rim, out-curving neck. Vague shoulder, ribbing on neck and body. Rounded base. Flattened vertical handle, attached at upper neck and mid body. Hard fired. Levigation: medium with some air pockets; inclusions: few lime and pebbles, many black spots.

References: Uscatescu, p. 258, no. 499; fig. 82; fig 20, no.3g-11; Lichtenberger et al. forthc.(c), no. 64.

Late Byzantine - Umayyad.

\section{Storage and transport vessels}

14. J14-Kh-32-1-3 + Kh-32-1-2

Amphora, intact profile.

Diam. (rim): 10,8;

H.: 47;

T.: 0,6-1.

Munsell: core: (inner): 2,5YR 3/1; (outer): 2,5YR 5/8; int.: 2,5YR 5/8; ext.: 10R 5/8.

Baggy shaped amphora with intact profile. Outwards thickened rim and oval tilted handle. Baggy ribbed body and pointed base. Ledge around shoulder. White strip deco.

References: Smith 1973, pl. 85; fig. 281; Clark 1986, pl. 13.26; Lichtenberger et al. forthc.(c), no. 72.

Byzantine - Umayyad.

Grey Ware

15. J14-Kg-40-7

Basin, intact profile.

Diam. (rim): 46;

Diam. (base): 30 ;

H.: 21,6;

T. (min.): 0,80;

T. (max.): 1,64 .

Munsell: core (inner): GLEY1 6/1; (outer): 2,5Y 6/2; int.: 7,5 YR 5/1; ext.: GLEY1 4/N.

Thickened rim. Combed decoration on exterior of body. Flattened vertical handle.

References: deco.: Smith 1973, fig. 1192.

Shape: McNicoll et al. 1992, pl. 114; fig. 8; Lichtenberger et al. forthc.(c), no. 82.

Byzantine - Umayyad.
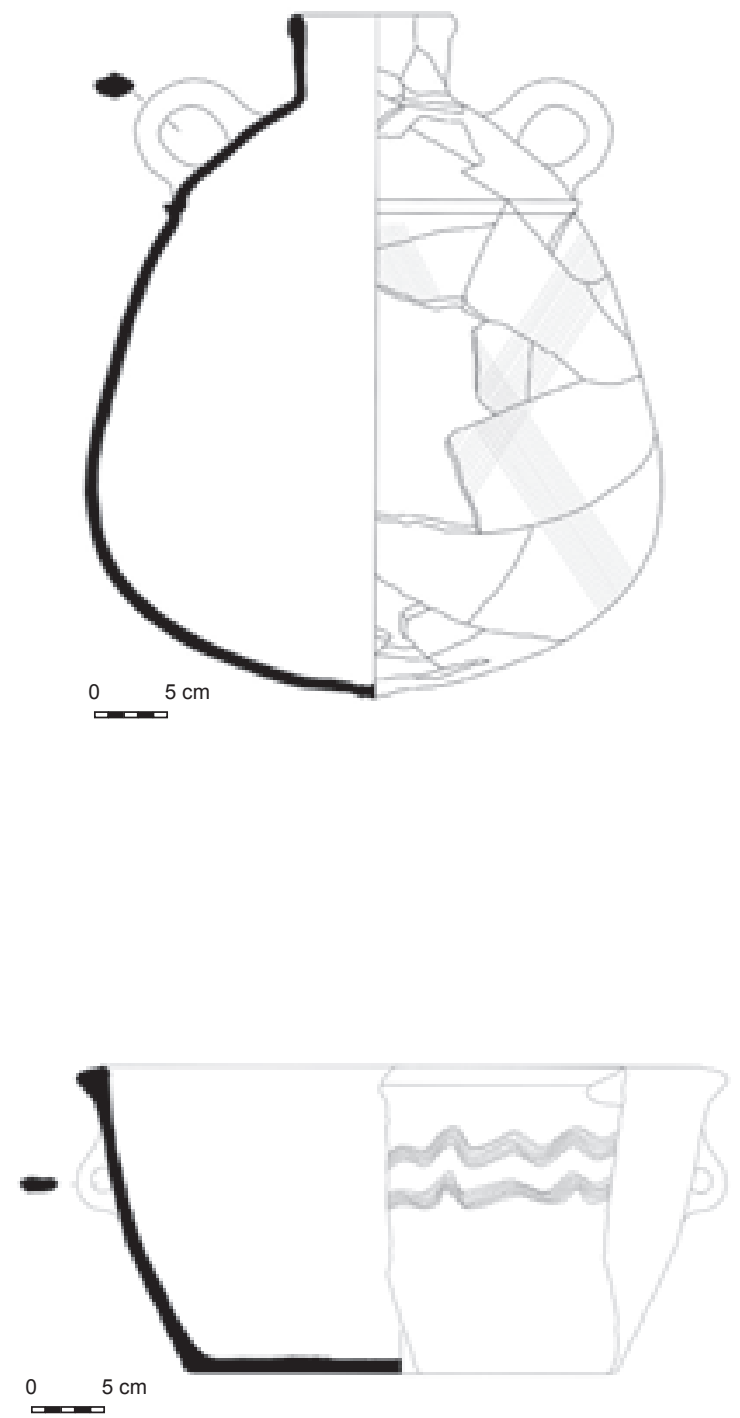


\section{Glass}

16. Kg-3-11X

Bottle, intact.

Diam. (rim): 2,94;

Diam. (max): 12,5;

Diam. (base) 2,$41 ; \mathrm{H}: 10,52$

Greenish, translucent. Outwards flattened rim, flat rounded base, squat globular body.

Umayyad

17. Kh-3-22X

Bottle, intact

Diam. (rim): 2,4;

Diam. (max): 9,8 ;

Diam. (base): 4,1; H: 9,3.

Dark green, translucent. Outwards flattened rim, flat base with convex centre, squat globular body.

Umayyad

18. Kg-39-14 + Kgh-3s-314A

Bottle, fragmented.

Diam. (rim): 4,8;

Diam. (max): 8,26;

Diam. (base): 4,47; H: 7,8

Greenish blue. Inwards folded rounded rim, pinched decoration on globular body; flat base.

Byzantine - Umayyad.

\section{Metal objects}

\section{Architectural fittings}

19. J14-Kh-34-5

Revetment pin. AE.

L.: 8,9;

W.: 1,2 ;

T.: 0,45 .

Oblong rectangular bar, ingot-shaped with a curved peg at one end.

References: Patrich 2008, p.441, 456; no.101-107; Waldbaum 1983, pp.66-67; pl. 19, no. 266-77; Lichtenberger et al. forthc.(c), no. 91.

Hellenistic/Roman and later.

20. J14-Kh-34-25

Revetment pin. AE.

L.: 7,1;

W.: 1 .

Oblong rectangular bar with a curved peg at one end.

References: Patrich 2008, no. 101-107; Lichtenberger et al. forthc.(c), no. 92.

Hellenistic/Roman and later.
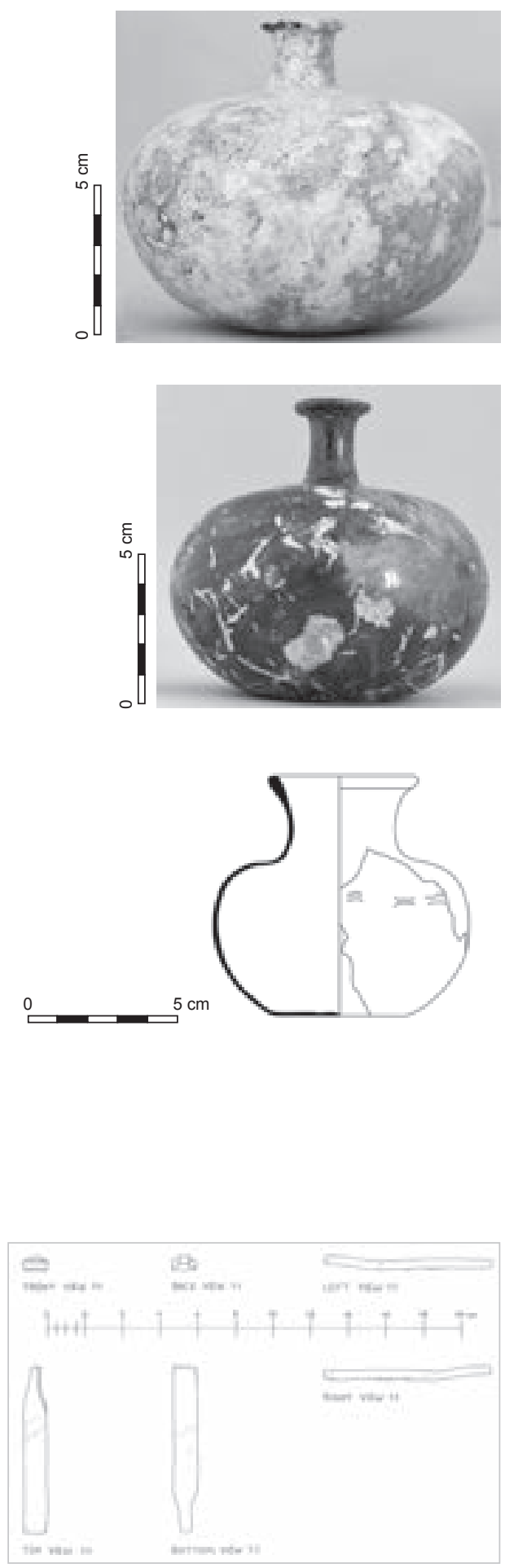
21. J14-Kh-34-13

Revetment pin (?). FE, badly corroded.

L.: 7;

W.: 107 ;

T.: 008.

References: Patrich 2008, p.441, 456, no.101-107; Waldbaum 1983, pp.66-67; pl. 19, no. 266-277; Lichtenberger et al. forthc.(c), no. 93.

Hellenistic/Roman and later.

22. J14-Kh-34-23

Fragment of unknown function/revetment pin (?).

Cat. ill. 22.

AE. L.: 9,9;

W.: 2,2 ;

T.: 1,4 .

Long bar with one rectangular end and one rounded end with a small peg.

References: Lichtenberger et al. forthc.(c), no. 94.

Hellenistic/Roman and later.

\section{Household appliance and tools}

23. J14-Kf-3-10x

Ladle/scoop.

FE, badly corroded.

L.: 72,6 ;

W.: 12,3 ;

W. eye: 5,7 .

Long handle with almost rectangular section; oval, plain bowl; at the opposite end a broken, circular eye.

References: Waldbaum 1983, p.60; pl. 16, no. 220-221; Baitinger and Völling 2007, p.92; pl. 31, no.376; Lichtenberger et al. forthc.(c), no. 95.

Hellenistic/Roman and later.

24. J14-Ke-3-17X+Kef-3s-343

Fragmented scissors.

FE, badly corroded.

L.: 31 ;

W.: 16 .

Triangular blades; the handle is made of a curved band. The top of one blade is missing.

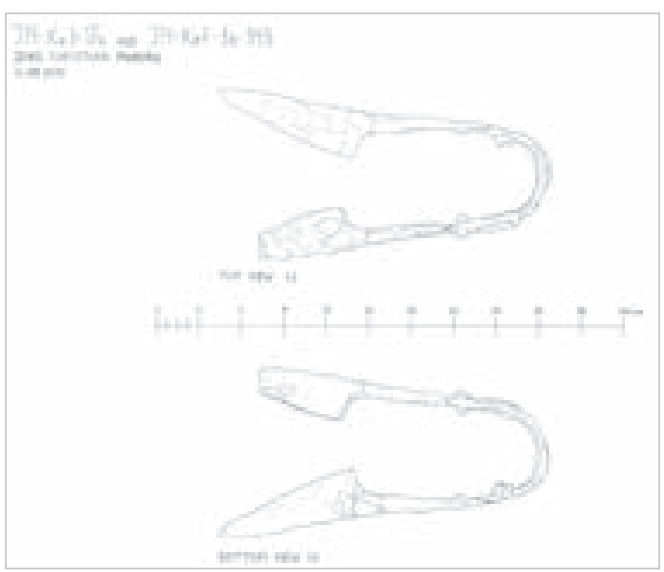

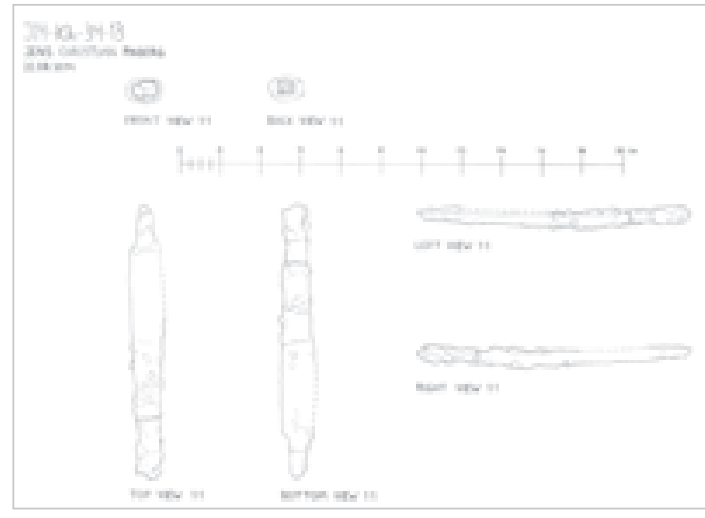
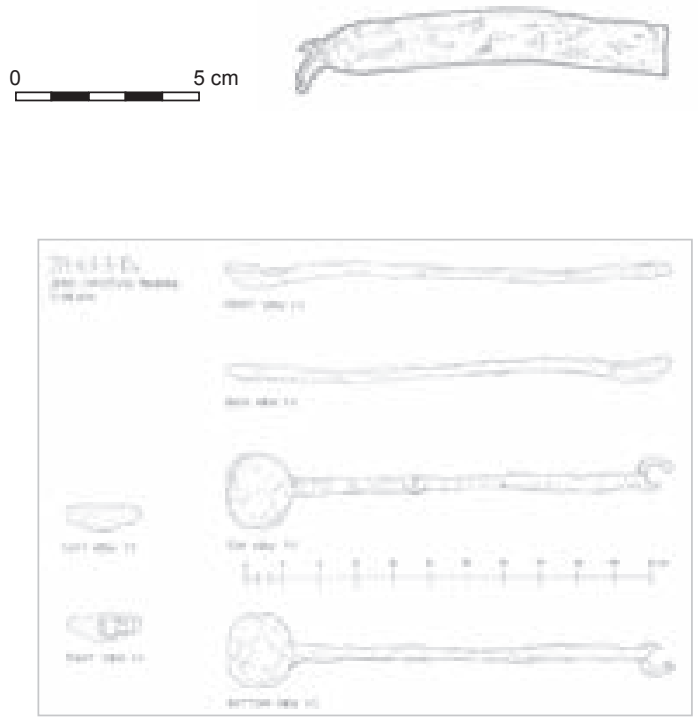

References: Patrich 2008, p.448, 458; no. 229; from Late Roman context: Künzl and Weber 1991, pp. 89-90; fig. 5; Lichtenberger et al. forthc.(c), no. 96.

Hellenistic/Roman and later.

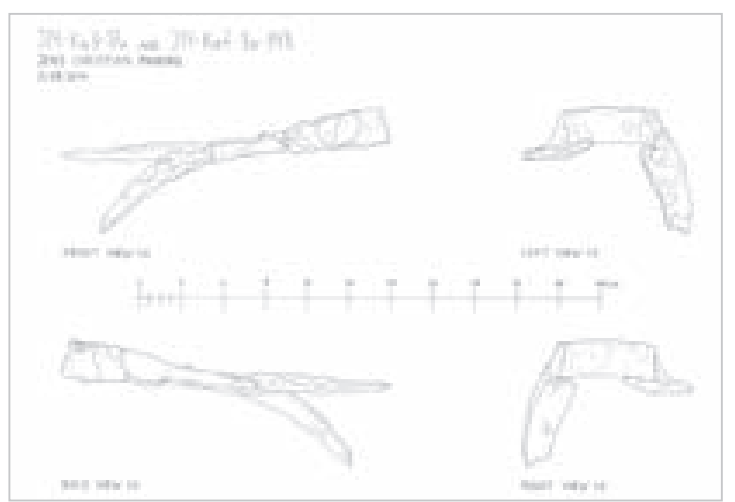


25. J14-Kg-3-13x

Fragments of a wool comb or heckling comb with dozens of teeth.

FE, badly corroded.

L. (max.): teeth 12.1 .

Long iron band with needle-shaped teeth, arranged in at least two rows.

References: Gaitzsch 2005, p.42; pl. 58, 75, no.1-2; Lichtenberger et al. forthc.(c), no. 97.

Hellenistic/Roman and later.

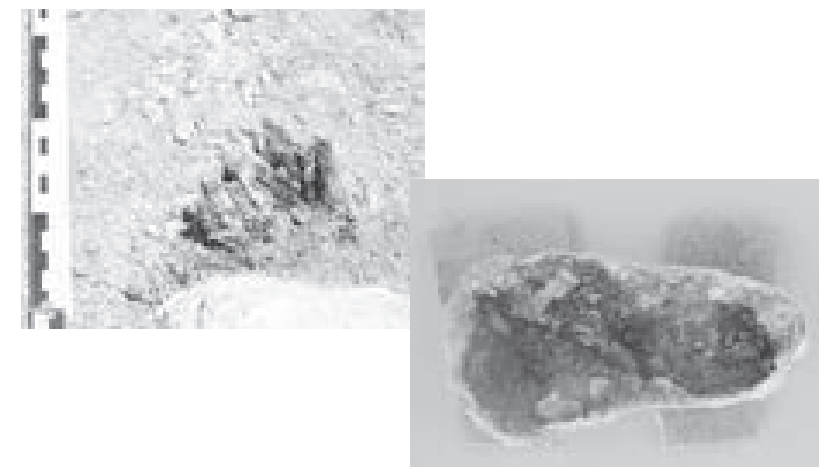

References: Patrich 2008, p.448, 458, no. 221-224; p. 467, no. 221; Waldbaum 1983, p. 61 ; pl. 17 , no. 230-234; Lichtenberger et al. forthc.(c), no. 98. Hellenistic/Roman and later.

27. J14-Kh-34-9

Needle.

FE, badly corroded.

L.: 19,3 ;

W.: 0,85 .

Long shaft with another small iron fragment adherent; an oblong eye is pierced through the flattened end.

References: Platt, Ray Jr. 2009, pp.177-178, 181; fig. 11.10, no.1-3; Waldbaum 1983, pp.61-62; pl.17, no. 231; Lichtenberger et al. forthc.(c), no. 98.

Hellenistic/Roman and later.
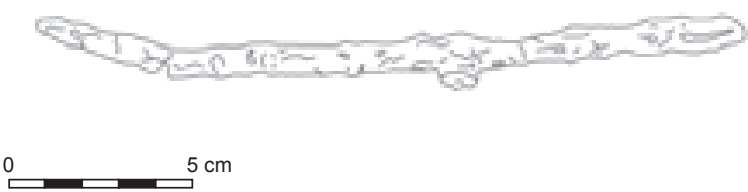

28. J14-Kh-34-8

Small knife (?).

FE, badly corroded.

L.: 9,2;

W.: 1,9 ;

T.: 1,1 .

Oblong, slightly conical handle; short triangular blade.

References: Waldbaum 1983, pl. 15, no. 199; Lichtenberger et al. forthc.(c), no. 100.

Hellenistic/Roman and later.

0 $5 \mathrm{~cm}$

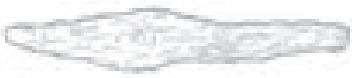

\section{Locks and keys}

29. J14-Kh-34-15

Small, casket-shaped object, probably a lock.

FE, badly corroded.

H.: 3,6 ;

L.: 4,9 ;

W.: 2,5 .

Rectangular casket, on one side open; a big hole at the front side; in each corner a small hole through which is passed a rivet.

References: Waldbaum 1983, pl. 23; Lichtenberger et al. forthc.(c), no. 101

Hellenistic/Roman and later.

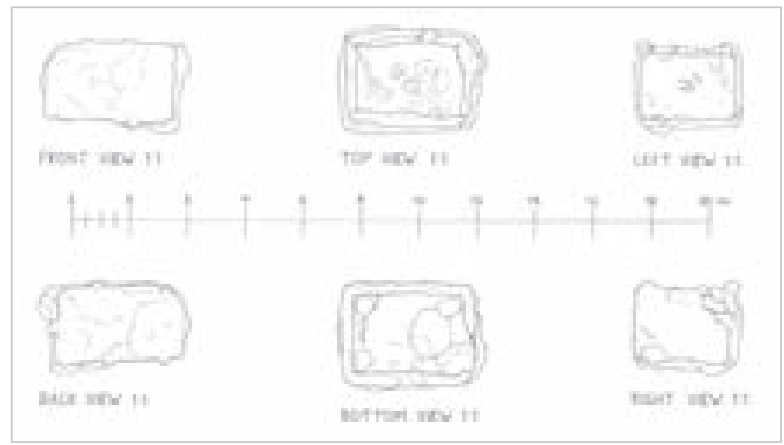


30. J14-Kh-34-16

Fragment of the closing device (?).

FE, badly corroded.

L.: 10,2 ;

H.: 4,9 ;

T.: 0,8 .

Rectangular band with an oblong eye which is attached on the upper ridge of the band.

References: Lichtenberger et al. forthc.(c), no. 102.

Hellenistic/Roman and later.

31. J14-Kg-3-14x

Keyhole plate.

AE.

Diam.: 6,5.

Circular plate with a central keyhole and a small rectangular hole on the upper right.

References: Waldbaum 1983, pp.72-73; pl. 24, no. 385; Baitinger and Völling 2007, pp. 138-142; pl. 56, no. 634; Jantzen 2004, pl. 32, no. 1184; Lichtenberger et al. forthc.(c), no. 103.

Byzantine/Late Byzantine.

32. J14-Kh-3-21x

Ring with movable key. AE.

L.: 2,9;

Diam.: ring 2,5;

L.: key 2,6 .

Ring with two dolphin head-shaped ends; small key with an eye at one

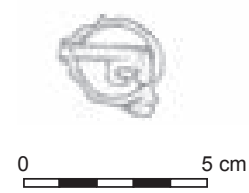

33. J14-Kh-3-27xa

Slide key.

FE, badly corroded.

L.: 11,5 ;

W.: 4,6 .

Key with long shaft and orthogonal bit with three teeth; the annular end of the handle is broken and fixed to the shaft.

References: Gaitzsch 2005, pl. 43, S12; Baitinger, Völling 2007, pp. 132-134; pl. 54; Seigne et al. 1986, p. 98; pl. 14, no. 1; Lichtenberger et al. forthc.(c), no. 105.

Hellenistic/Roman and later.

\section{Casket fittings}

34. J14-Kh-34-22

Hinge/hinge-plate.

AE.

L.: 12,8 ;

W.: 2,5 .

Flat bar with a knuckle at one end and a rounded, perforated extension at the other end. Face with decorated with chased geometrical ornament (concentric circles and small dots).
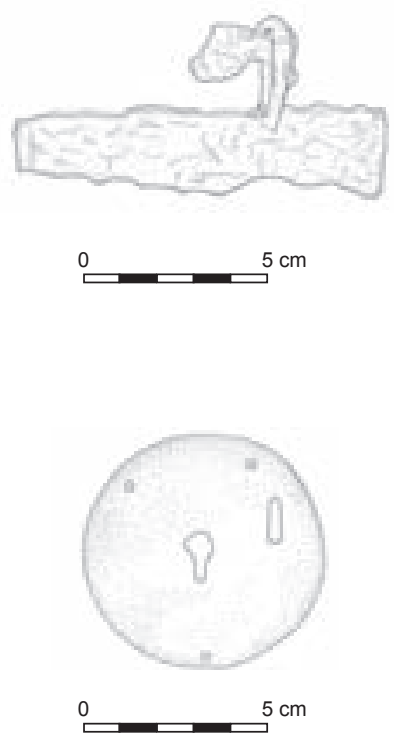

end which is linked to a short axis between the dolphin heads.

References: Patrich 2008, p.422, 428; no. 16; Waldbaum 1983, p. 76; pl. 25, no. 403-107; Jantzen 2004, pl. 33, no. 1189; Lichtenberger et al. forthc.(c), no. 104. Late Byzantine.

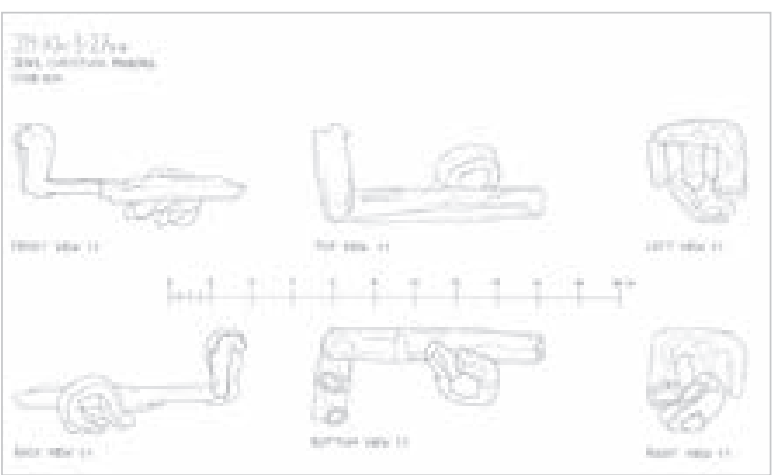

References: Waldbaum 1983, pp.6-78; pl. 26, no.417-118; Jantzen 2004, pl. 31, no. 1159-1163; Lichtenberger et al. forthc.(c), no. 106.

Byzantine/Late Byzantine.
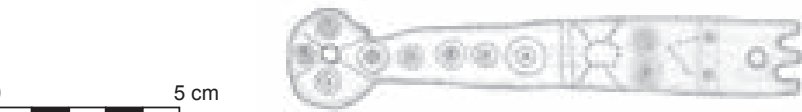
35. J14-Kh-34-12

Small attachment, probably a stand/food of a casket.

$\mathrm{AE}$.

H.: 3,1 ;

W.: 3,3 ;

T.: 1,6 .

Massive "foot" with triangular extension.

References: Davidson 1942, pl. 52, no. 560; pl. 62, no. 837;

Lichtenberger et al. forthc.(c), no. 107.

Roman - Late Byzantine.

36. J14-Kh-34-18

Hinge.

FE, badly corroded.

L.: 3,8 ;

W.: 2,8 ;

T.: 1,2 .

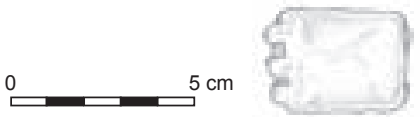

\section{Weighing equipment}

37. J14-Kh-34-1

Weight. AE.

L.: 4;

W.: 3,9 ;

T.: 0,25 . $5 \mathrm{~cm}$

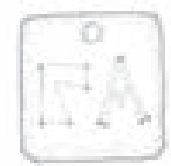

38. J14-Kh-24-4

Suspension of a balance.

AE.

L.: 6,8

W.: 0,6 .

Solid upper part with pseudo-torsion profile which ends in a loop with movable ring; the lower part is divided in two flat legs.

References: Waldbaum 1983, pp. 82-84; pl. 29, no. 448, 460; Lichtenberger et al. forthc.(c), no. 110.

39. J14-Kh-34-26

Suspension, probably from a balance.

AE.

L.: 9,7;

W.: 1 .

Short, solid upper part with a loop; the lower part is divided in two long and flat legs each are perforated through the lower end.

\section{Cosmetic implements}

40. J14-Kef-3s-339

Rim fragments of a mirror (?).

$\mathrm{PB}$.

L.: largest fragment 3,3;

W.: 1,2 .

Six fragments of an openwork frame with zigzag ornament; probably parts of the same frame like the fragments Khg-3s-311.

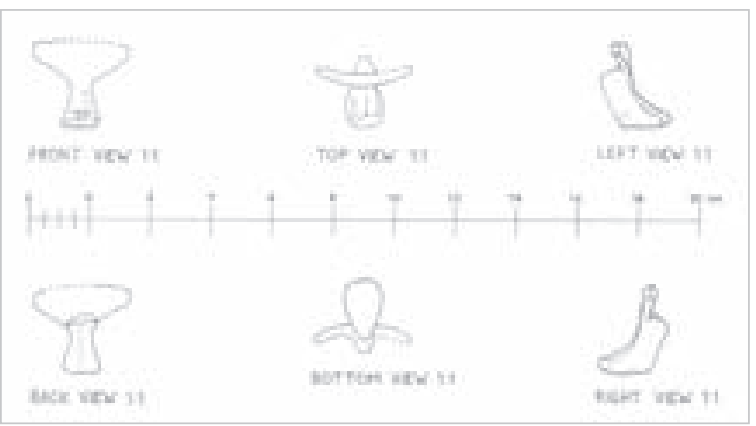

Rectangular plate with three eyes of the knuckle. References:; Lichtenberger et al. forthc.(c), no. 108. Hellenistic/Roman and later.

Flat rectangular plate; face chased with two letters, Gamma and Alpha (= weight of one ounze), and a small, dotted circle.

References: Wamser 2004, pp. 362-363; Bendall 1996, pp. 29-38; Lichtenberger et al. forthc.(c), no. 109.

Late Byzantine.

Hellenistic/Roman and later.

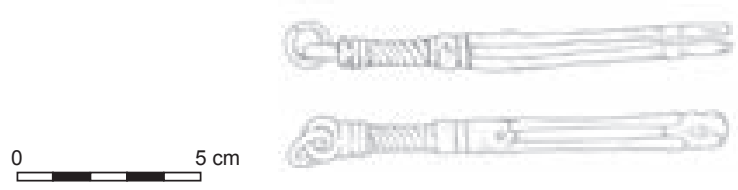

References: Waldbaum 1983, pp. 82-84; pl. 29, no. 448, 460; Lichtenberger et al. forthc.(c), no. 111. Roman and later.
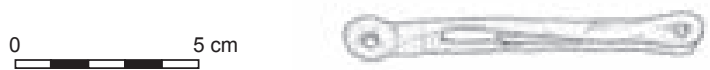

References: Patrich 2008, p.425, 430; no.73-79; Lichtenberger et al. forthc.(c), no. 112. Hellenistic/Roman and later.
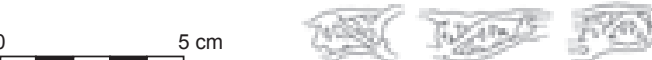
41. J14-Kgh-3s-311

Rim fragments of a mirror (?).

PB.

L.: largest piece 2,7;

W.: 1,3 .

Three fragments of an openwork frame with zigzag ornament; probably parts of the same frame like Kef-3s-339.

42. J14-Kh-34-11

Lid of a cosmetic tube.

$\mathrm{AE}$.

H.: 2,7;

Diam.: 2,2.

Cylindrical hull, closed at one end; with a little hole in centre.

References: Waldbaum 1983, p.108; pl. 41, no.644; Lichtenberger et al. forthc.(c), no. 114.

Hellenistic/Roman and later.

\section{Dress accessories}

43. J14-Ke-3-211

Model for a strap end.

AE.

L.: 3,4;

W.: 1,1

U-shaped plate; face with engraved ornament of stylized vegetable character.

References: Schulze-Dörrlamm 2009, pp. 268-270; Lichtenberger et al. forthc.(c), no. 116.

Late Byzantine.

44. J14-Kh-34-27

Strap end.

$\mathrm{AE}$.

L.: 6;

W.: 2,5 .

U-shaped; upper end slightly fluted, with two little perforations for lost rivets.

References: Kazanski 2003, p.122; fig. 14, no.37; Lichtenberger et al. forthc.(c), no. 117.

Late Byzantine.

\section{Horse trappings (?)}

45. J14-Kh-34-2

Buckle.

FE, badly corroded.

L.: 4,4;

W.: 5,2 ;

T.: 1,6 .

Almost rectangular loop with eyes at the end of both arms which hold a pivoted axis; a triangular tongue is linked with the central, fixed axis.

References: Jantzen 2004, pl. 20, no. 748; similar buckles of copper alloy, but just with one pivoted axis: Patrich 2008, p. 458, no. 211-212; Lichtenberger et al. forthc.(c), no. 118.

Roman - Late Byzantine.
References: Patrich 2008, p.425, 430; no.73-79; Lichtenberger et al. forthc.(c), no. 113.

Hellenistic/Roman and later.
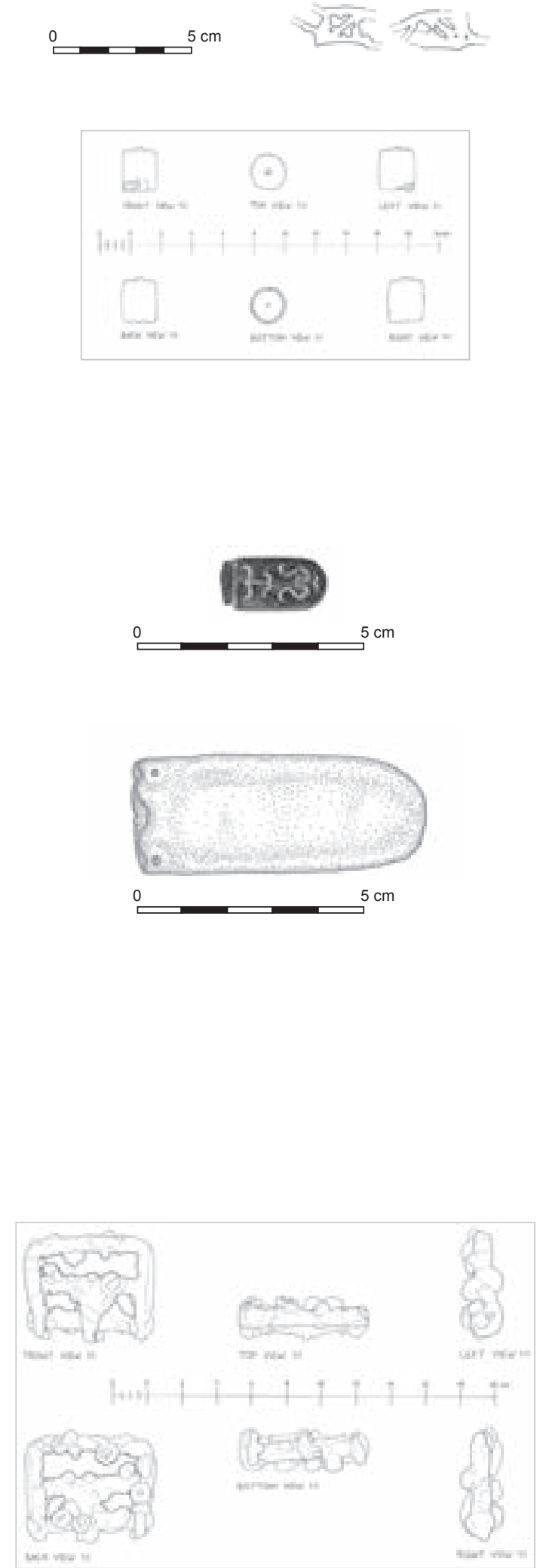
46. J14-Ke-3-7x

Loop of a buckle (?).

$\mathrm{AE}$.

L.: 5,6 ;

B.: 3,7 .

Almost rectangular loop with extended rounded ends each perforated to hold a pivoted axis that is lost.

References: Patrich 2008, p. 458, no. 211-212; Lichtenberger et al. forthc.(c), no. 119.

Roman - Late Byzantine.

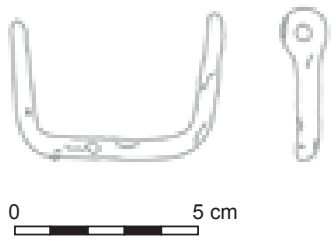

\section{Chains and hooks}

47. J14-Kh-34-7

Fragment of a chain.

FE.

L.: 4,9;

W. (hook): 1,9 .

Two chain links, each shaped by two different sized loops, like a distorted "8".

48. J14-Kh-34-10

Bracket, probably of a chain.

$\mathrm{AE}$.

L.: 7,3;

W.: 1,4 .

Flat plate of oblong triangular shape. Two extended, rounded ends each perforated.

References: Waldbaum 1983, pp. 101-102; pl. 38, no. 591-592; Jantzen 2004, pl. 1, no. 1-2; Lichtenberger et al. forthc.(c), no. 122.

Byzantine/Late Byzantine.

\section{J14-Kh-34-14}

Fragment of a chain.

$\mathrm{FE}$, badly corroded and contaminated with other material.

L.: single link ca. 3,6;

W.: 1,35 .

A cluster of several oblong oval chain links.

References: Lichtenberger et al. forthc.(c), no. 123.

Hellenistic/Roman and later.

\section{Nails and rivets}

50. J14-Kh-34-4

Button/head of a rivet (?).

PB (?).

Diam.: 1,6;

T.: 0,15 .

Flat, slightly concave and discoid piece of metal.

References: Lichtenberger et al. forthc.(c), no. 126.

Roman - Late Byzantine.
References: Platt 2009, pp. 278-279; fig. 13.23, no. 9;

Lichtenberger et al. forthc.(c), no. 121.

Hellenistic/Roman and later.

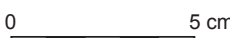

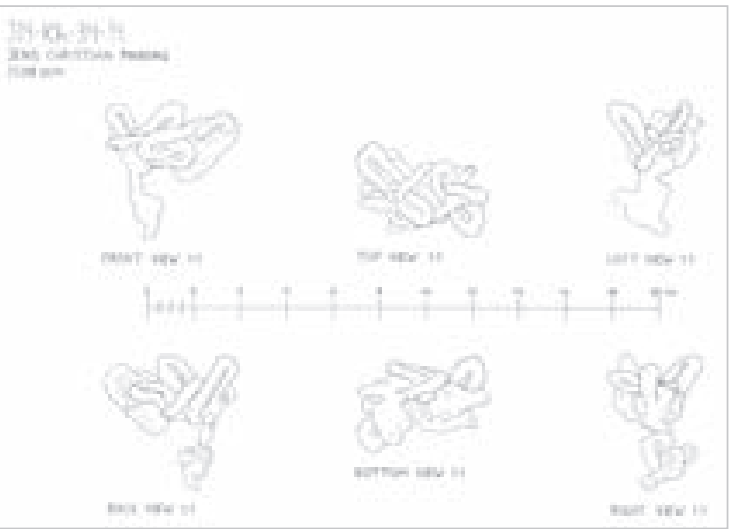

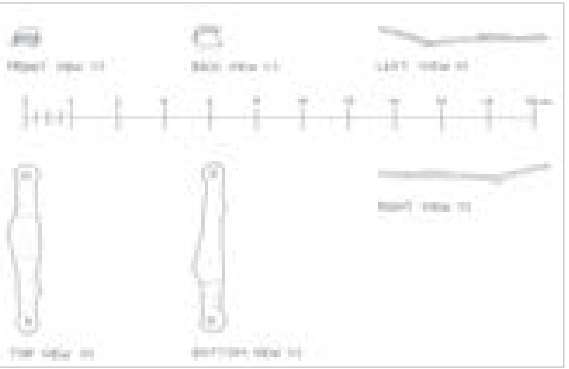

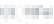

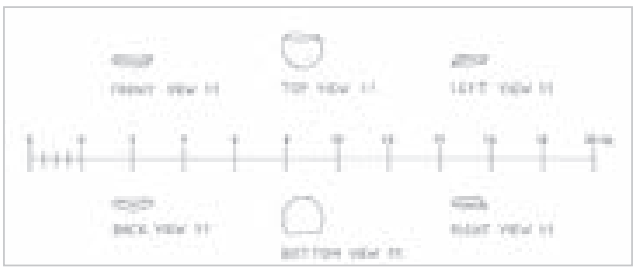


51. J14-Kh-34-21

Boss or decorated head of a rivet (?).

AE.

L.: 5,9;

Diam.: 1,6

Solid, oblong vase-shaped.

0

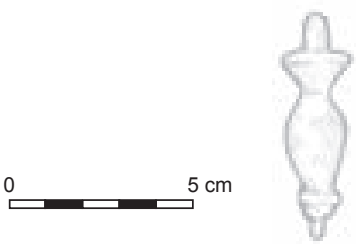

52. J14-Kh-34-31+ 32

Two small nails/rivets.

a: J14-Kh-34-31

b: J14-Kh-34-32

FE, badly corroded.

$\mathrm{L} 1,5$ and 1.

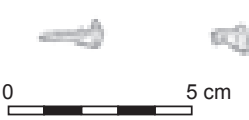

\section{Varian}

53. J14-Kh-34-3

Tube/hull of unknown function.

$\mathrm{AE}$, heavily corroded and contaminated with other material.

Diam. (max.): 2;

L.: 6,2 .

Almost cylindrical tube.

References: Lichtenberger et al. forthc.(c), no. 134.

Hellenistic/Roman and later.

\section{J14-Kh-34-6}

Fitting.

FE, badly corroded and contaminated with other material.

L.: 9,1;

W.: 2,4 ;

T.: 1,25 .

Oblong, originally rectangular bar with eyeholes at the ends through both are passed a small rivet.

References: Lichtenberger et al. forthc.(c), no. 135.

Hellenistic/Roman and later.
References: Waldbaum 1983, pp.64-65; pl. 18, no.260; Lichtenberger et al. forthc.(c), no. 127.

Hellenistic/Roman and later.

Each of them with round, slightly convex head.

References: Patrich 2008, p. 439, 455, no.61-68; Lichtenberger et al. forthc.(c), no. 128.

Hellenistic/Roman and later.
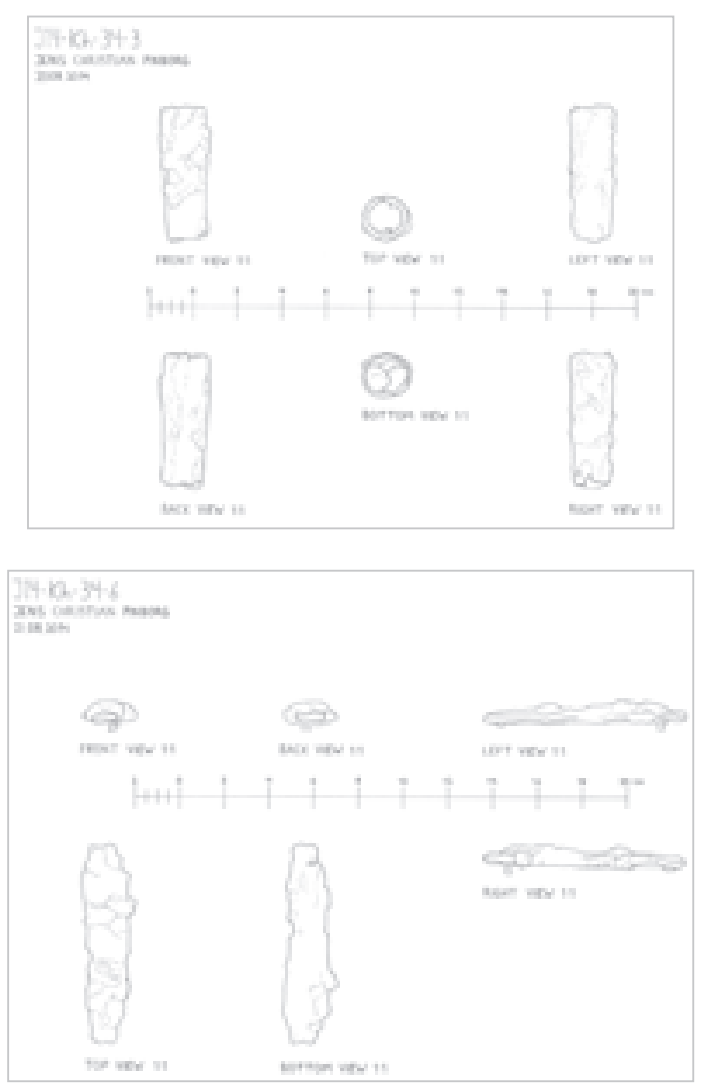

\section{Bone Utensils}

55. J14-Kh-34-24

Worked bone disc, intact.

Diam.: 2; T.: 0,43.

Circular worked bone disc; eight incised circles along outer edge, each circle has a central incised dot; from which incised lines are connected to the circles along the outer edge; possibly a game piece.

References: Macalister 1912, vol. 2, p. 303, fig. 443; vol. 3, pl. 132, no. 45, 47, 49; pl. 195, no. 61, 61a, 72; Ayalon 2005, fig. 28, 29; Kotter, Ray Jr. 2009, fig. 9.27, no. 11; fig. 9.28, no. 1, 5; Lichtenberger et al. forthc.(c), no. 147. Not datable.

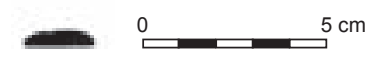


56. J14-Kh-3-26x

Worked bone cylinder, intact.

Diam.: 2,84;

L.: 10,91 ;

T.: 0,54 .

Worked bone cylinder, six incised lines at both ends of the cylinder; slight ribbed surface; possibly a container or (mirror?) handle.

References: McNicoll et al. 1992, pl. 72, no. 6; Findlater et al. 1998, pp. 69-83, fig. 7, 9; Ayalon 2005, fig. 1, no. 1-3; Wapnish 2008, pp. 587-638, fig. 34, no. 5; Kotter, Ray Jr. 2009, fig. 9.27, no. 8; Panitz-Cohen et al. 2009, fig. 16.12, no. 2; Lichtenberger et al. forthc.(c), no. 152.

Late Roman - Mid Byzantine.

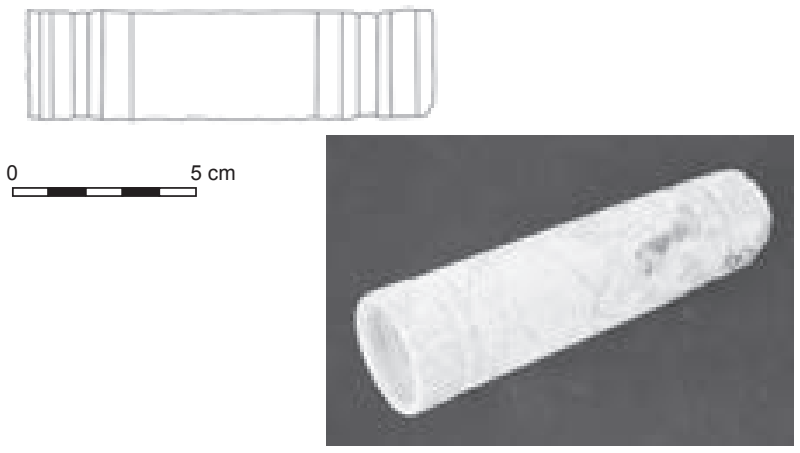

\section{Spindle Whorls}

57. J14-Kh-34-19

Diam. (min.): 0,5;

Diam. (max.): 2,7;

H.: 1,74 ;

W.: 0,89-2,7;

Wt.: 17.

Almost intact cone-shaped spindle whorl with central hole; flat base; steep sides; slight circular depression at the top; dark bluishblack stone.

References: Ploug et al. 1969, fig. 39, no. 8; Riis, Buhl 1990, fig. 97, no. 752-765; McNicoll et al. 1982,

58. J14-Kh-34-20

Diam. (min.): 0,5 ;

Diam. (max.): 2,5;

H.: 1,15 ;

W.: $0,60-2,68$;

WTO: 11,37 .

Almost intact cone-shaped spindle whorl with central hole; flat base; curving sides; dark greenish-black stone.

59. J14-Kh-3s-303

Steatite.

Diam. (min.): 0,86;

Diam. (max.): 2,56;

H: 2,7 ;

T.: 0,86 ;

WTO: 11,87 .

Almost intact cone-shaped spindle whorl with a central hole; flat top and base, black steatite.

60. J14-Ke-3-210

Bonge.

Diam. (min.): 0,7;

Diam. (max.): 3,1;

H.: 1,2 ;

WTO: 9,23 .

Almost intact cone-shaped spindle whorl with a central hole; flat base, curving sides; bone.

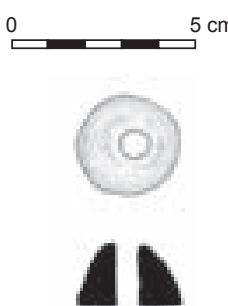

pl. 132, no. 7; McNicoll et al. 1992, pl. 69, no. 8; Platt, Ray Jr. 2009, fig. 11.5, no. 6-11; Lichtenberger et al. forthc. (a), no. 158, 159; forthc.(b), no. 143; Lichtenberger et al. forthc.(c), no. 154.

Not datable.

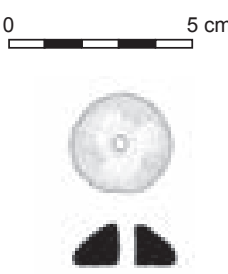

References: Ploug et al. 1969, fig. 39, no. 8; Riis, Buhl 1990, fig. 97, no. 752-765; McNicoll et al. 1982, pl.132, no. 7; McNicoll et al. 1992, pl. 69, no. 8; Platt, Ray Jr. 2009, fig. 11.5, no. 6-11; Lichtenberger et al. forthc.(a), no. 158, 159; forthc.(b), no. 144; Lichtenberger et al. forthc.(c), no. 155.

Not datable.

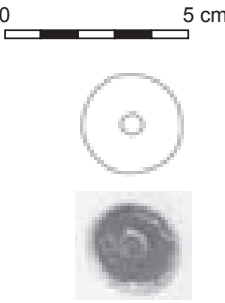

References: Ploug 1969, fig. 39, no. 8; Riis, Buhl 1990, fig. 97, no. 752-762; McNicoll et al. 1982, pl.132, no. 7; McNicoll et al. 1992, pl. 69, no. 8; Platt, Ray Jr. 2009, fig. 11.5, no. 6-11; Lichtenberger et al. forthc.(a), nos. 158 and 159; forthc.(b), no. 144; Lichtenberger et al. forthc.(c), no. 156 .

Not datable.

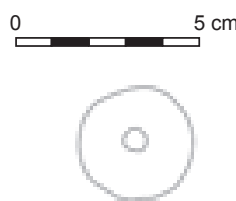

References: Dever et al. 1986, pl. 56, no. 4; pl. 59, no. 9 McNicoll et al. 1992, pl. 46, no. 3, 9; Lichtenberger et al. forthc.(c), no. 157

Not datable. 
61. J14-Kgh-3s-309

Rock krystal.

Diam. (min.): 0,68;

Diam. (max.): 2,9;

H.: 1,97 ;

L.: 3,19 ;

W.: 3,08 ;

WTO: 22,17 .

Intact trapezoidal spindle whorl with a central hole; flat base; curving sides; upper surface is worked in trapezoidal patterns; worked hexagon around central hole; rock crystal, clear.
References: Lichtenberger et al. forthc.(c), no. 158. Not datable.

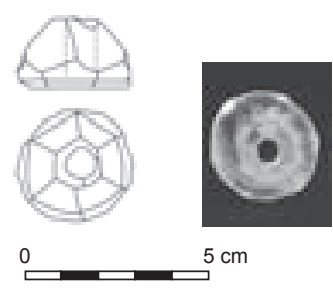

References: Riis 1948, fig. 203; Lichtenberger et al. forthc. (c), no. 159.

62. J14-Kgh-3s-315, 316, 317, 318, Kg-3N-419, J14-Kg-39-6, 7

Metal beads.

a, f: Kg-39-6: L.: 1,4; W.: 0,7

b, f: Kgh-3s-315: L.: 1,43; W.: 0,85

c, f: Kgh-3s-316: L.: 1,29; W.: 0,80

d, f: Kgh-3s-317: L.: 1,27; W.: 0,87

e, f: Kgh-3s-318: L.: 1,44; W.: 0,84

f: Kg-3N-419: L.: 0,76; W.: 0,70

and Kg-39-7: L.: 1,4; W.: 0,8.

Cylindrical shaped (419 is globular shaped) lead beads, coated with golden foil, pierced through lengthwise.

\section{J14-Kf-3-476}

Two metal beads

No. 1: L.: 0,33; W.: 0,38

No. 2: L.: 0,65; W.: 0,78

No. 1: AE. Circular, bronze plate, central hole; No. 2: AE. Two, circular bronze beads, corroded.

64. J14-Kgh-3s-320

Stone bead.

L.: 1,39 ;

W.: 0,61 .

Agate.

Cylindrical shaped, agate stone bead, pierced through the small sides, coloured in stripes in dark brown, white and light brown.

65. J14-Kgh-3s-321

Stone bead.

L.: 1,07 ;

W.: 0,62 .

Agate.

Cylindrical shaped, agate stone bead, pierced through the small sides, coloured in a dark brown part, separated from a very light brown one by a white line.

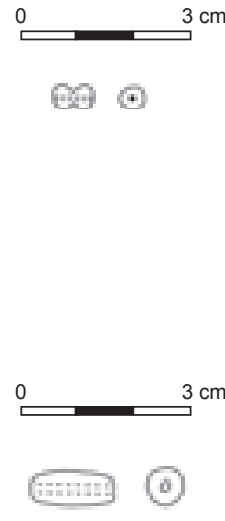

References: Lichtenberger et al. forthc.(c), no. 160. Not datable.

References: Plou 1985, p.209; Riis 1948, fig. 203; Lichtenberger et al. forthc.(c), no. 161. Not datable.

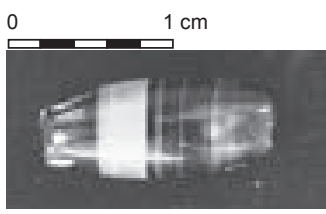

References: Plou 1985, fig. 209; Riis 1948, fig. 203; Lichtenberger et al. forthc.(c), no. 162. Not datable.
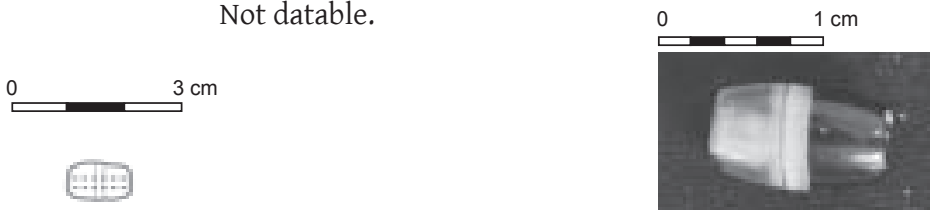
66. J14-Kg-3D-412

Stone bead.

L.: 1,34 ;

W.: 0,77 .

Cylindrical shaped carnelian bead, pierced through the small sides.
0

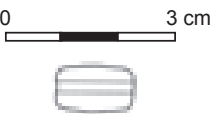

References: Plou 1985, fig. 209; Riis 1948, fig. 203; Lichtenberger et al. forthc.(c), no. 163.

Not datable.
67. J14-Kg-3D-413

Stone bead.

L.: 1,22 ;

W.: 0,76 .

Carnelian.
0

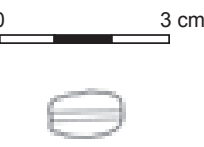

Cylindrical bead, pierced through the small sides.

References: Plou 1985, fig. 209; Riis 1948, fig. 203; Lichtenberger et al. forthc.(c), no. 164

Not datable.

68. J14-Kg-3N-419

Stone bead.

L.: 0,89;

W.: 0,77 .

Ovoid-shaped, white and dark brown/ black coloured semi-precious stone bead. Pierced through on the short sides.

References: Riis 1948, fig. 203; Lichtenberger et al. forthc.(c), no. 165.

Not datable.

69. J14-Kh-3-520

Stone bead.

L.: 1,65 ;

W.: 0,9 ;

Diam. (hole): 0,34.

Cylindrical, blackish-brown stone bead. Pierced hole in the centre of the small sides.

References: Lichtenberger et al. forthc.(c), no. 166.

Not datable.

70. J14-Ke-41s-7

Stone bead, almost intact.

H.: 1,03;

Diam.: $1,17$.

Carnelian.

Circular reddish-brown carnelian stone, partly broken off. Remains of a bronze wire, sticking in the pierced hole.

References: Plou 1985, fig. 209; Riis 1948, fig. 203, Lichtenberger et al. forthc.(c), no. 167.

Not datable.

71. J14-Kg-39-8

Stone bead.

L.: 1,35 ;

W.: 1,0 .

Circular, white stone bead, possibly made of quartz, pierced through on the small sides.

References: Riis 1948, fig. 203, 204; Smith 1973, pl. 80, Lichtenberger et al. forthc.(c), no. 168.

Not datable.
0
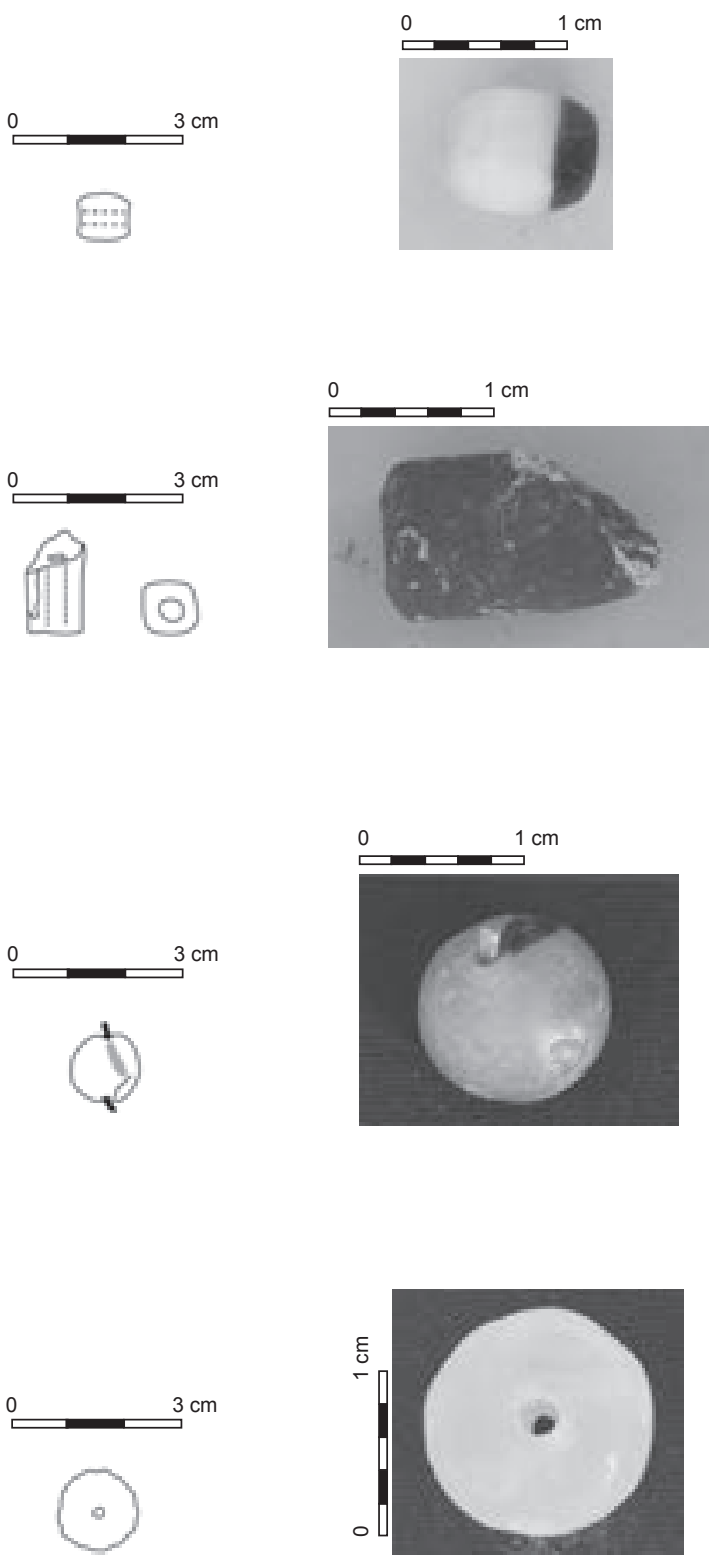
72. J14-Kg-39-9

Semi-precious stone bead.

L.: 1,5 ;

W.: 0,7

The red brown/light brown bead is cylindrically elongated (thicker in the middle) and has white stripes running around it. Pierced through at the small side.

References: Riis 1948, fig. 203, Lichtenberger et al. forthc. (c), no. 169.

Not datable.

73. J14-Kh-3-450

Stone pendant.

T.: 0,60;

Diam.: 2,43.

Flat disc pendant. Yellowish stone with light brown stripes. Pierced hole in centre.

References: Riis, Buhl 1990, fig. 107, Lichtenberger et al. forthc.(c), no. 170.

Not datable.

\section{J14-Kgh-3s-322}

Bone bead.

L.: 2,15;

W.: 0,88 .

Black bone bead, secondarily burned, drilled hole through the small side. Surface full of cracks and flaking off.

References: Riis 1948, fig. 203; Smith 1973, pl. 80, Lichtenberger et al. forthc.(c), no. 171.

Not datable.

\section{J14-Kh-3-523}

Glass bead.

H.: 1,03;

Diam.: 1.13;

Diam. (hole): 0,27.

Opaque, white/light blueish glass bead, hole in centre of the small sides.

References: Riis 1948, fig. 203; Nicol et al. 1992, pl. 73; Smith 1973, pl. 80; Lichtenberger et al. forthc.(c), no. 172. Not datable.

\section{J14-Kh-3-514}

Finger ring, fragmented.

Measurements not available.

Half a bronze ring, very corroded, with a whitish/blue glass pearl (weathered) inserted in depression on top.

References: Plou 1985, fig. 54 I; Lichtenberger et al. forthc. (c), no. 173 .

Not datable.
0
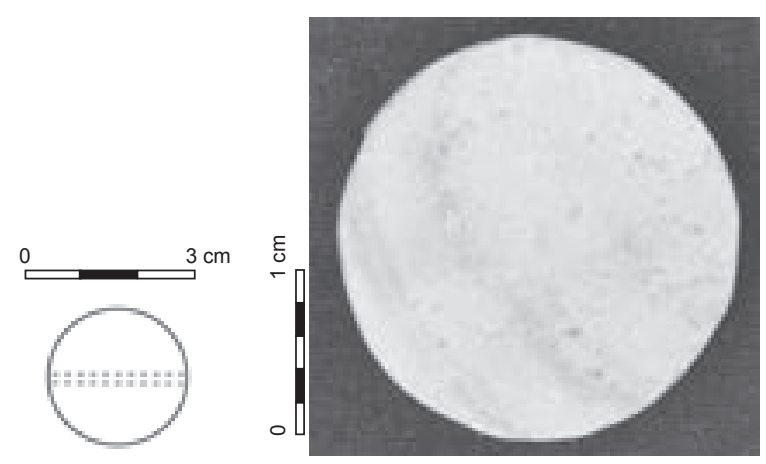

0
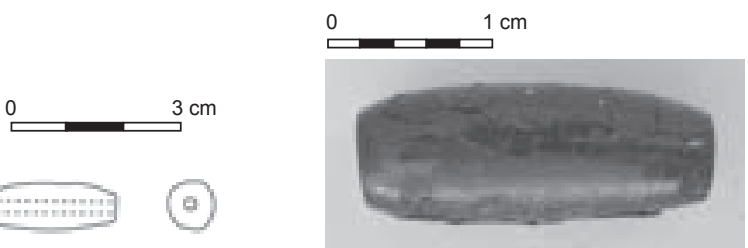

0
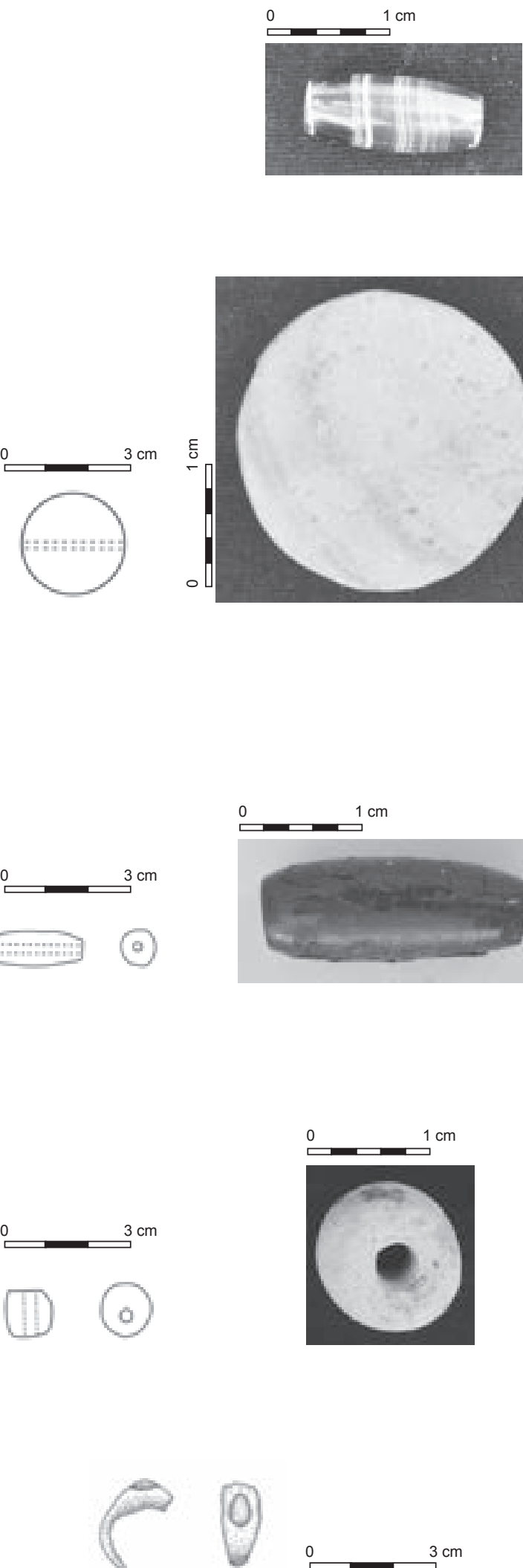


\section{Stone vessel}

77. J14-Ke-23-1

Mortar with pestle, intact.

Morter: H.: 9,0; W.: 13,2; endestation: 4,8; W.: 8,4

Pastel: H.: 6,0; W. (min.): 2,6; W. (max): 3,6; endestation: 1,8

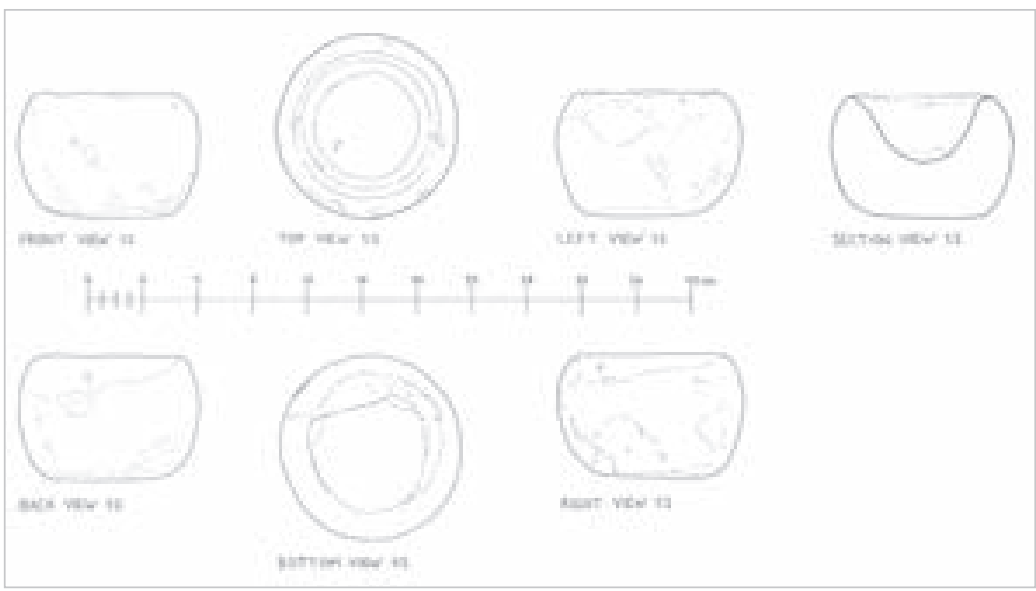

Small grey-yellowish limestone mortar with pestle. slightly weathered.

References: McNicoll et al. 1992, pl. 6; Lichtenberger et al. forthc.(c), no. 183.

Not datable. 
BiBLIOGRPAHY*

al-Khouly M.

2001 "Nouvelles lampes inscrites de la période omeyyade," in E. Villeneuve (dir.), La céramique byzantine et proto-islamique en Syrie-Jordanie (IVeVII siècles apr.J.C.), Beyrouth, pp. 193-196.

'Amr A.-J.

1988 "Shallow Umayyad painted bowls from Rujm elKursi excavations," ADAJ 32, pp. 247-254.

Andrade N. J.

2013 Syrian Identity in the Greco-Roman World, Cambridge.

Ayalon E.

2005 The Assemblage of Bone and Ivory Artefacts from Caesarea Maritima, Israel 1st-13th Centuries CE (BAR International Series 1457), Oxford.

Avni G.

2014 The Byzantine-Islamic Transition in Palestine. An Archaeological Approach, Oxford.

Baitinger H., Völling T.

2007 Werkzeug und Gerät aus Olympia, Berlin / New York.

Barfod G.H., Larsen J.M., Lichtenberger A., Raja R.

2015 "Revealing text in a complexly rolled silver scroll from Jerash with computed tomography and advanced imaging software," Nature Scientific Reports 5, pp. 17765 (doi:10.1038/srep17765).

Bendall S.

1996 Byzantine Weights: An Introduction, London.

Blanke L., Damgaard K., Simpson I., Walmsley A.

2007 "From bathhouse to congregational mosque: Further discoveries on the urban history of Islamic Jerash," ADAJ 51, pp. 177-197.

Blanke L., Lorien P.D., Rattenborg R.

2010 "Changing cityscapes in central Jarash - between Late Antiquity and the Abbasid period," ADAJ 54, pp. 311-328.

Clark V.A.

1986 "Part II. The Archaeology of the Roman Theatre," in Zayadine (dir.) 1986, pp. 231-302.

Clark V.A., Bowsher J.

1986 "A note on soundings in the Northwestern quarter of Jerash," in Zayadine (dir.) 1986, pp. 343-349.

Clark V.A., Bowsher J., Stewart D.

1986 "The Jerash north theater: architecture and archaeology. 1982-1983," in Zayadine (dir.) 1986, pp. 205-302.

* Abbreviations: ADAJ = Annual of the Department of Antiquities of Jordan.
Clark V.A., Falkner R.K.

1986 "The pottery," in Clark 1986.

Crowfoot J.W.

1938 "The Christian churches," in Kraeling (dir.) 1938, pp. 171-262.

Crowfoot J.W., Hamilton R.W.

1929 "The discovery of a synagogue in Jerash," Palestine Exploration Quarterly 61, pp. 211-219.

Davidson G.R.

1952 The Minor Objects, Corinth 12, Princeton.

Day E.F.

1942 "Early Islamic and Christian lamps," Berytus 7, pp. 65-79.

Detweiler A.H.

1938a "The north gate," in Kraeling (dir.) 1938, pp. 117-124.

1938b “The south gate," in Kraeling (dir.) 1938, pp. 149-152.

Dever W.G., Lance H.D., Bullard R.G.

1986 Gezer 4: The 1969-71 Season in Field 6, the "Acropolis". Part 2 Plates, Plans, 4, Jerusalem.

Dvorjetski E.,

2005 "The synagogue-church at Gerasa in Jordan. A contribution to the study of ancient synagogues," Zeitschrift des Deutschen Palästina-Vereins 121, pp. 140-167.

Findlater G., El-Najjar M., Al-Shiyab A.-H., O'Hea M., Easthaugh E. 1998 "The Wadi Faynan Project: the South Cemetery excavation, Jordan 1996: a preliminary report," Levant 30, pp. 69-83.

Fischer C.S.

1938a "Description of the site," in Kraeling (dir.) 1938, pp. 11-26.

1938b “The Temple of Artemis," in Kraeling (dir.) 1938, pp. 125-138.

1938c "Buildings of the Christian period," in Kraeling (dir.) 1938, pp. 265-296.

Foote R.M.

2000 "Commerce, industrial expansion, and orthogonal planning: Mutually compatible terms in settlements of Bilad al-sham during the Umayyad period," Meditarch 13, pp. 25-38.

Gaitzsch W

2005 Eisenfunde aus Pergamon. Geräte, Werkzeuge und Waffen. Mit einem Beitrag von G. Gassmann und A. Hauptmann (Pergamenische Forschungen 14), Berlin / New York.

Gawlikowski M.

1986 "A residential area by the South Decumanus," in Zayadine (dir.) 1986, pp. 107-136. 
Gawlikowski M., Musa A.

1986 "The Church of Bishop Marianos," in Zayadine (dir.) 1986, pp. 137-162.

Jantzen U.

2004 Die Wasserleitung des Eupalinos. Die Funde (Samos 20), Bonn.

Kalaitzoglou G., Kniess R., Lichtenberger A., Pilz D., Raja R.

2012 "Report on the geophysical prospection of the Northwest Quarter of Gerasa/Jerash 2011," ADAJ 56, pp. 79-90.

Kalaitzoglou G., Lichtenberger A., Raja R.

forthc.(a) "Preliminary report of the second season of the Danish-German Jerash Northwest Quarter Project 2012," ADAJ 57.

forthc. (b) "Preliminary report of the third season of the Danish-German Jerash Northwest Quarter Project 2013," ADAJ 58.

forthc. (c) "Preliminary report on the fourth season of the Danish-German Northwest Quarter Project 2014," ADAJ 59.

Kazanski M.

2003 Qal'at Sem'an IV: Rapport final, 3: Les objets métalliques, Beyrouth.

Kehrberg, I.

2011 "Roman Gerasa seen from below: An alternative study of urban landscape," Australasian Society for Classical Studies 32, pp. 1-18.

Kehrberg I., Manley J.

2001 "New archaeological finds for the dating of the Gerasa Roman city wall," ADAJ 45, pp. 437-446.

2002 "The 2001 season of the Jarash City Walls Project: Preliminary report," ADAJ 46, pp. 197-203.

2003 "The Jerash City Walls Project (JCWP) 2001-2003: report of preliminary findings of the second season 21st September-14th October 2002," ADAJ 47, pp. 83-86.

Kennedy D.

2007 Gerasa in the Decapolis: A "Virtual Island" in Northwest Jordan (Duckworth Debates in Archaeology), London.

Kennedy H.

1985 "From Polis to Madina: urban change in Late Antique and Early Islamic Syria," Past and Present 106, pp. 3-27.

Khairy I.N., 'Amr A.-J.

1986 "Early Islamic inscribed pottery lamps from Jordan," Levant 18, pp. 143-153.

Kotter W.R., Ray Jr. P.J.

2009 "Objects of stone, clay, bone, and ivory from Tell Hesban and vicinity," in P.J. Ray Jr. (dir.), Small Finds: Studies of Bone, Iron, Glass, Figurines, and Stone Objects from Tell Hesban and Vicinity (Hesban 12), Berrien Springs, pp. 113-146.

Kraeling C.H.

1938 "The history of Gerasa," in Kraeling (dir.) 1938, pp. 27-72.
Kraeling C.H. (dir.)

1938 Gerasa, City of the Decapolis, New Haven (CT).

Künzl E., Weber T.

1991 "Das spätantike Grab eines Zahnarztes zu Gadara in der Dekapolis," Damaszener Mitteilungen 5, pp. 81-118.

Lauffer S. (dir.)

1971 Diokletians Preisedikt, Berlin.

Lepaon T.

2011 "Un nouveau plan pour Jerash/Gerasa (Jordanie)," ADAJ 55, pp. 409-420.

Levine L.I.

2000 The Ancient Synagogue: The First Thousand Years, New Haven.

Lichtenberger A.

2003 Kulte und Kultur der Dekapolis: Untersuchungen zu numismatischen, archäologischen und epigraphischen Zeugnissen (Abhandlungen des Deutschen Palästina-Vereins 29), Wiesbaden.

2008 "Artemis and Zeus Olympios in Roman Gerasa and Seleucid religious policy," in T. Kaizer (dir.), The Variety of Local Religious Life in the Near East in the Hellenistic and Roman Periods, Leiden, pp. 133-154.

Lichtenberger A., Lindroos A., Raja R., Heinemeier J.

2015 "Radiocarbon analysis of mortar from Roman and Byzantine water management installations in the Northwest Quarter of Jerash, Jordan," Journal of Archaeological Science: Reports 2, pp. 114-127.

Lichtenberger A., Raja R.

2012 "The International Jerash Northwest Quarter Project: Results of the 2011 Survey Campaign," ADAJ 56, pp. 231-240.

2015a "Intentional cooking pot deposits in Late Roman Jerash (Northwest Quarter)", Syria: Archéologie, Art et Histoire 92, pp. 309-328.

2015b "A hoard of Byzantine and Arab-Byzantine coins from Jerash," Numismatic Chronicle 175, pp. .299-308

2016a "Living with and on the river-side: The example of Roman Antiochia-on-the-Chrysorrhoas-formerly-called-Gerasa," in J. Kuhlmann (dir.), Water of Life. Festschrift for Peder Mortensen, Copenhagen, pp. 88-117.

2016b "Jerash in the Middle Islamic period. Connecting texts and archaeology through new evidence from the Northwest Quarter," Zeitschrift des Deutschen Palästina-Vereins, 132, pp. 63-81.

2016c "The Danish-German Northwest Quarter Project in Jerash. Results from the 2011-2013 campaigns," Studies in the History and Archaeology of Jordan 12, Amman, pp. 173-188.

Lichtenberger A., Raja R., Sørensen A. H.

forthc.(a) "Preliminary registration report of the second season of the Danish-German Jerash Northwest Quarter Project 2012," ADAJ 57.

forthc. (b) "Preliminary registration report of the third season of the Danish-German Jerash Northwest Quarter Project 2013," ADAJ 58. 
forthc. (c) "The Danish-German Jerash Northwest Quarter Project 2014. Preliminary registration report," ADAJ 59.

MacAlister S. R. A.

1912 The Excavation of Gezer: 1902-1905 and 1907-1909 (3 vol.), London.

March C.

2009 Spatial and Religious Transformations in the Late Antique Polis: A Multidisciplinary Analysis with a Case-Study of the City of Gerasa, Oxford.

McNicoll A.W., Edwards P.C., Hanbury-Tenison J., Hennessy J.B., Potts T.F., Smith R.H., Walmsley A., Watson P.

1992 Pella in Jordan 2: The Second Interim Report of the Joint University of Sydney and College of Wooster Excavations at Pella 1982-1985, Sydney.

McNicoll A.W., Smith R.H., Hennessy B.

1982 Pella in Jordan 1: An Interim Report on the Joint University of Sydney and The College of Wooster Excavations at Pella 1979-1981, Canberra.

Najjar M.

1989 "Abbasid pottery from el-Muwaqqar," ADAJ 33, pp. 305-322.

Panitz-Cohen N., Mazar A. (dir.)

2006 Timnah(Tel Batash), 3. Finds from the Second Millennium BCE (Qedem, 42), Jerusalem.

Panitz-Cohen N., Yahalom-Mack N., Mazar A.

2009 "Various finds: clay, stone, ivory, bone and faience objects and vessels," in N. Panitz-Cohen, A. Mazar (dir.), Excavations at Tel Beth-Shean 1989-1996, 3. The 13th-11th Century BCE Strata in Areas N and S, Jerusalem, pp. 742-763.

Parapetti R.

1989 "Jerash: the Sanctuary of Artemis," in D. HomésFredericq, J.B. Hennessy (dir.), Archaeology of Jordan, 2, 1: Field Reports, Surveys and Sites A-K \& L-Z (Akkadica Supplementum 7), Leuven, pp. 323-329.

2002 "Gerasa und das Artemis-Heiligtum," in A. Hoffmann, S. Kerner (dir.), Gadara-Gerasa und die Dekapolis (L'Antiquité Classique 74, 1), Mainz, pp. 23-35.

Patrich J.

2008 Archaeological Excavations at Caesarea Maritima Areas CC, KK and NN. Final Reports, 1. The objects, Jerusalem.

Pierobon R.

1983 "Gugliemo di Tiro e il castrum di Gerasa," Prospettive Settanta 1, pp. 8-13.

1984 "Gerasa in archaeological historiography," Mesopotamia 18-19, pp. 13-35.

Platt E.E.

2009 "The cosmetic objects from Tell Hesban and vicinity," in P.J. Ray Jr. (dir.), Small Finds: Studies of Bone, Iron, Glass, Figurines, and Stone Objects from Tell Hesban and Vicinity (Hesban 12), Berrien Springs, pp. 199-224.
Platt E.E., Ray Jr. P.J.

2009 "The textile tools from Tell Hesban and vicinity," in P.J. Ray Jr. (dir.), Small Finds: Studies of Bone, Iron, Glass, Figurines, and Stone Objects from Tell Hesban and Vicinity (Hesban 12), Berrien Springs, pp. 163-196.

Ploug G.

1985 Hama: Fouilles et Recherches de la Fondation Carlsberg, 1931-1938, III.1: The Graeco-Roman Town, Copenhagen.

Ploug G., Hammershaimb E., Oldenburg E., Thomsen R.

1969 Hama: Fouilles et Recherches de la Fondation Carlsberg, 1931-1938, IV.3: Les Petits Objets Médiévaux sauf Les Verreries et Poteries, Copenhagen.

Raja R.

2009 "The Sanctuary of Artemis in Gerasa," in T. FisherHansen, B. Poulsen (dir.), From Artemis to Diana: The Goddess of Man and Beast (Acta Hyperborea 12), Copenhagen, pp. 383-401.

2012 Urban Development and Regional Identity in the Eastern Roman Provinces, 50 BC-AD 250: Aphrodisias, Ephesos, Athens, Gerasa, Copenhagen.

2013 "Changing spaces and shifting attitudes: Revisiting the Sanctuary of Zeus in Gerasa," in T. Kaizer, A. Leone, E. Thomas, R. Witcher (dir.), Cities and Gods: Religious Space in Transition (Babesch Supplements 22), Leuven, pp. 31-46.

2015 "Bishop Aeneas and the Church of St. Theodore in Gerasa," in J. Rüpke, E. Rebillard (dir.), Group identity and religious individuality in Late Antiquity, Washington, pp. 270-292.

Rasson A.M., Seigne J.

1986 "Une citerne byzantino-omeyyade sur le Sanctuaire de Zeus," in Zayadine (dir.) 1986, pp. 117-151.

Retzleff A., Mjely A. M.

2004 "Seat inscriptions in the Odeum at Gerasa," Bulletin of the American Schools of Oriental Research 336, pp. 37-47.

Riis P.J.

1948 Hama: Fouilles et Recherches de la Fondation Carlsberg, 1931-1938, II.3. Les Cimetières à Crémation, Copenhagen.

Riis P.J., Buhl M.L.

1990 Hama: Fouilles et Recherches de la Fondation Carlsberg, 1931-1938, II.2. Objets de la Période dite Syro-Hittite, Copenhagen.

Schulze-Dörrlamm M.

2009 Byzantinische Gürtelschnallen und Gürtelbeschläge im Römisch-Germanischen Zentralmuseum, 2: Die Schnallen mit Scharnierbeschläg und die Schnallen mit angegossenem Riemendurchzug des 7. bis 10. Jahrhunderts (Katalog vor- und frühgeschichtlicher Altertümer 30, 2), Mainz.

Schaefer J., Falkner B.K.

1986 “An Umayyad potters' complex in the north theatre, Jerash," in Zayadine (dir.) 1986, pp. 411-435. 
Schumacher G.

1902 "Dscherasch," Zeitschrift des Deutschen PalästinaVereins 25, pp. 109-177.

Seigne J.

1989 "History of exploration at Jerash: the Sanctuary of Zeus," in D. Homés-Fredericq, J.B. Hennessy (dir.), Archaeology of Jordan, 2, 1: Field Reports, Surveys and Sites A-K \& L-Z (Akkadica Supplementum 7), Leuven, pp. 319-323.

1992a "Jérash romaine et byzantine : développement urbain d'une ville provinciale orientale," in S. Tell (dir.), Studies in the History and Archaeology of Jordan, 4, Amman, pp. 331-341.

1992b “À l'ombre de Zeus et d'Artémis, Gerasa de la Décapole,” ARAM Periodical 4, pp. 185-195.

Seigne J., Augé C., Braemer F., Dentzer-Feydey J., Montlivault-Villeneuve E.G. de, Dussart O., Gatier P.-L., Rasson-Seigne A.M.

1986 "Recherches sur le sanctuaire de Zeus à Jerash: Octobre 1982-décembre 1983: Rapport préliminaire," in Zaydine (dir.) 1986, pp. 29-59.

Simpson I.

2009 "Market buildings at Jarash: Commercial transformation at the Tetrakionion in the $6^{\text {th }}$ to $9^{\text {th }}$ centuries C.E.," in K. Bartl, A.-R. Moaz (dir.), Residences, Castles, Settlements. Transformation Processes from Late Antiquity to Early Islam in Bilad al-Sham (Proceedings of the International Conference held at Damascus, 5-6 November 2006), Rahden, pp. 115-124.

Smith R

2011 "Walls of the Decapolis," ARAM Periodical 23, pp. 489-508.

Smith R.H.

1973 Pella of the Decapolis, 1: The 1967 Season of the College of Wooster Expedition to Pella, Wooster.

Tholbecq L.

1997-1998“Une installation d'époque islamique dans le sanctuaire de Zeus de Jérash (Jordanie): La céramique," ARAM Periodical 9-10, 1pp. 53-179.

Tsafrir Y., Foerster G.

1992 "The dating of the "Earthquake of the Sabbatical Year' of 749 C.E. in Palestine," Bulletin of the School of Oriental and African Studies 55, pp. 231-235.

1997 "Urbanism at Scythopolis-Bet Shean in the fourth to seventh centuries," DOP 51, pp. 85-146.

Uscatescu A.

1996 La Cerámica del Macellum de Gerasa (Yarash, Jordania), Madrid.

Vida T.

2009 "Local or foreign Romans? The problem of the late antique population of the $6^{\text {th- }} 7^{\text {th }}$ centuries $A D$ in Pannonia," in D. Quast (dir.), Foreigners in Early Medieval Europe. Thirteen International Studies on Early Medieval Mobility (Monograohien des RömischGermanischen Zentralmuseums 78), Mainz, pp. 233-260.
Waldbaum J.

1983 Metalwork from Sardis: The Finds Through 1974 (Archaeological Exploration of Sardis, 8), Cambridge (Mass.).

Walker B. J.

2012 "The Islamic Period," in J.A. Sauer, L.G. Herr (dir.), Ceramic Finds: Typological and Technological Studies of the Pottery Remains from Tell Hesban and Vicinity (Hesban 11), Berrien Springs (MI), pp. 507-593.

Walmsley A.

1996 "Byzantine Palestine and Arabia: Urban prosperity in Late Antiquity," in N. Christie, S. T. Loseby (dir.), Towns in Transition: Urban Evolution in Late Antiquity and the Early Middle Ages, Aldershot, pp. $126-158$

1997 "Land, resources and industry in Early Islamic Jordan ( $7^{\text {th }}-11^{\text {th }}$ century). Current research and future directions," in G. Bisheh (dir.), Studies in the History and Archaeology of Jordan, 6, Amman, pp. 345-351.

2000 "Production, exchange and regional trade in the Islamic East Mediterranean: Old structures, new systems?," in L. Hansen, C. Wickham (dir.), The Long Eight Century: Production, Distribution and Demand, Leiden, pp. 265-344.

2003 "The Friday Mosque of Early Islamic Jarash in Jordan: the 2002 field season of the Danish-Jordanian Islamic Jarash Project," Journal of the C. L. David Collection 1, pp. 111-131.

2005 "The village ascendant in Byzantine and Early Islamic Jordan: Socio-economic forces and cultural responses," in J. Lefort, C. Morrisson, J.-P. Sodini (dir.), Les Villages dans l'Empire Byzantin, IV $V^{e}-X V^{e}$ siècle, Paris, pp. 511-522.

2007 Early Islamic Syria (Debates in Archaeology), London.

Walmsley A., Damgaard K.

2005 "The Umayyad congregational mosque of Jarash in Jordan and its relationship to early mosques," Antiquity 79, pp. 362-378.

Walmsley A., Macumber P. G., Edwards P. C.

1993 "The eleventh and twelfth season of excavations at Pella (Tabaqat Fahl), 1989-1990," ADAJ 37, pp. 165-240.

Wamser L.

2004 Die Welt von Byzanz-Europas östliches Erbe: Glanz, Krisen und Fortleben einer tausendjährigen Kultur, Darmstadt.

Wapnish P.

2008 "The manufacture of bone artefacts", in L.E. Stager, J.D. Schloen, D.M. Master (dir.), Ashkelon 1: Introduction and Overview (1985-2006), Winona Lake (Ind.), pp. 587-638.

Ward-Perkins B

2001 "Specialisation, trade, and prosperity: an overview of the economy of the Late Antique Eastern Mediterranean," in S.A. Kingsley, M. Decker (dir.), Economy and Exchange in the East Mediterranean during Late Antiquity, Oxford, pp. 167-178. 
Wharton A. J.

1996 Reconfiguring the Post-Classical City: Dura Europos, Jerash, Jerusalem and Ravenna, Cambridge.

Whitcomb D.

1992 "Reassessing the archaeology of Jordan of the Abbasid period," in S. Tell (dir.), Studies in the History and Archaeology of Jordan, 4, Amman, pp. 385-390.

Zayadine F. (dir.)

1986 Jerash Archaeological Project 1981-1983, Amman. 
